\title{
AVALIAÇÃO LABORATORIAL DE MISTURAS ASFÁLTICAS SMA PRODUZIDAS COM LIGANTE ASFALTO-BORRACHA
}

Dissertação apresentada à Escola de Engenharia de São Carlos da Universidade de São Paulo, como parte dos requisitos para obtenção do Título de Mestre em Engenharia Civil - Área de Concentração: Transportes.

ORIENTADOR: Prof. Associado José Leomar Fernandes Júnior

São Carlos 
Ficha Catalográfica preparada pela Seção de Tratamento da Informação do Serviço de Biblioteca - EESC/USP

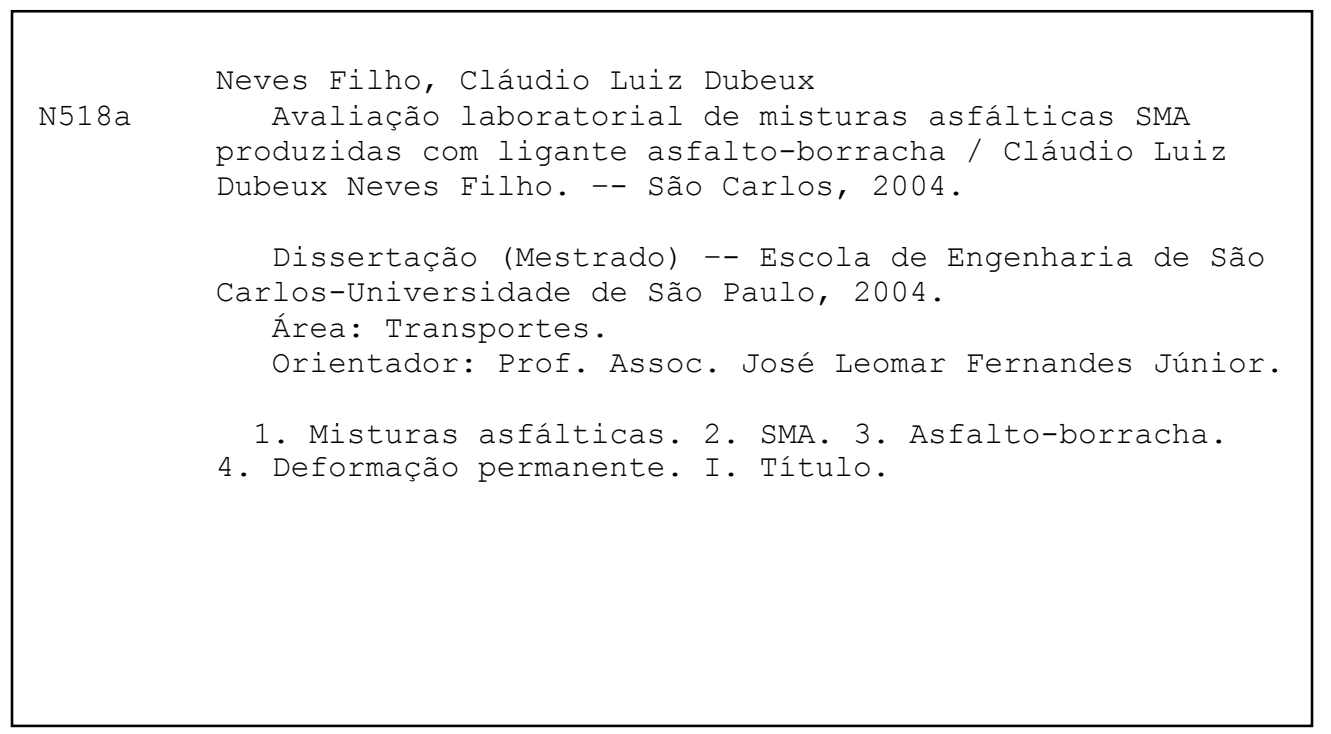


Dedico este trabalho a meus pais, Ângela e Cláudio, por todo apoio, incentivo, amor e carinho. 


\section{AGRADECIMENTOS}

Ao meu orientador Prof. José Leomar Fernandes Júnior, pelo ensinamentos não apenas como professor mas também como grande amigo;

À Prof. ${ }^{a}$ Dra. Liedi Légi Bariani Bernucci, por disponibilizar as instalações do LTPEPUSP e pelos conselhos ao longo do desenvolvimento do trabalho;

A Edson Moura e Erasmo do LTP-EPUSP, por toda a ajuda nos ensaios de laboratório e pela amizade;

A minhas irmãs Cristiana, Marcela e Denise, pelo amor e carinho, e por estarem sempre por perto;

A Marcela, por tudo que ela fez por mim desde que estamos juntos e pelo amor e carinho que compartilhamos;

À diretoria do QG/Base Aérea: Rômulo, João Marcello, Alexandre (Topó), Ricardinho, Marcão, Rafael (Babuê), Everton, Gustavo, Mário, Renato;

Aos amigos do Departamento de Transportes, em especial: Ana Furlan, André, Carlos Prado, Cida, Claudia, Lobão, Fábio, Fred, Genival, Giovane, Josiane, João Mota, Joel, Lílian, Manuel Lucas, Marcos, Massulo, Pablo, Paulo César, Renatinho, Rodrigo, Rogério, Simone, Tule e os outros que não foram citados, mas que também fizeram parte dessa amizade;

Aos professores do Departamento de Transportes, em especial ao Prof. Glauco Fabbri e Prof. Paulo César Segantine pelos conhecimentos compartilhados e pelos momentos de amizade;

Aos funcionários do Departamento de Transportes, em especial a Magali, Lilian, Paulo (Japonês), João, Gigante e Toco pela amizade, atenção e pelos inúmeros serviços prestados; 
À Ipiranga Asfaltos, em especial a Rafael Reis, Anelise Zanon e Humberto Nascimento;

À Ecofibras, em especial a Eduardo Sâmara;

Ao Laboratório de Materiais Avançados a Base de Cimento (SET-EESC-USP), em especial ao Prof. Jéferson, a Samir e a Marcos;

À FAPESP pelo apoio financeiro concedido para realização do trabalho. 


\section{RESUMO}

NEVES FILHO, C. L. D. (2004). Avaliação Laboratorial de Misturas Asfálticas SMA produzidas com ligante asfalto-borracha. Dissertação (Mestrado) - Escola de Engenharia de São Carlos, Universidade de São Paulo, São Carlos, 2004.

As misturas asfálticas do tipo SMA apresentam granulometria descontínua, composta por uma maior fração de agregados graúdos, uma rica massa de ligante/fíler (mastique) e aproximadamente $4 \%$ de volume de vazios. Possuem um esqueleto pétreo de alta estabilidade devido ao contato pedra-pedra, que proporciona uma maior resistência à deformação permanente. Geralmente o teor de ligante asfáltico é superior a $6 \%$, formando uma película asfáltica mais espessa. São utilizadas fibras para evitar o escorrimento do ligante durante as etapas de produção e lançamento e, geralmente, são usados asfaltos modificados por polímero. Esta pesquisa tem por objetivo avaliar se o ligante asfalto-borracha possibilita misturas asfálticas SMA capazes de atender aos valores limites de aceitação e, por meio de ensaios de laboratório (resistência à tração, módulo de resiliência, fadiga e deformação permanente em simulador de tráfego), comparar o comportamento de misturas SMA com diferentes tipos de ligante (asfalto convencional CAP 20, modificado por polímero e asfalto-borracha) com um concreto asfáltico convencional de granulometria contínua (Faixa C do DNER). Os resultados obtidos apresentam o comportamento de uma mistura SMA com asfalto-borracha muito mais próximo de misturas SMA produzidas com um ligante modificado por polímero do que com um asfalto convencional.

Palavras-chave: misturas asfálticas, SMA, asfalto-borracha, deformação permanente. 


\section{ABSTRACT}

NEVES FILHO, C. L. D. (2004). Laboratory evaluation of SMA asphalt mixtures produced with asphalt-rubber binder. M.Sc. Dissertation - Escola de Engenharia de São Carlos, Universidade de São Paulo, São Carlos, 2004.

SMA is a gap-graded asphalt mixture with a large proportion of high quality coarse aggregate, a high content of mastic (binder/filler), and approximately $4 \%$ of air voids. The larger proportion of coarse aggregate provides a greater stone-to-stone contact, which results in a mixture more resistant to permanent deformation than the conventional Hot Mix Asphalt (HMA). The asphalt content is typically greater than 6.0 percent, which increases the film thickness. Fibers are used to prevent drainage of the asphalt binder during the HMA production and placement, and polymer-modified asphalt cements are usually used. This research aims to evaluate if an asphalt-rubber binder produces SMA mixtures able to meet the technical requirements. The behavior of SMA mixtures produced with different binders (conventional AC-20, polymermodified, and asphalt-rubber) is analyzed based on laboratory tests (tensile strength, resilient modulus, fatigue, and permanent deformation in a traffic simulator) and compared to the behavior of a conventional dense-graded HMA The results show that the behavior of SMA mixtures produced with asphalt-rubber is much closer to SMA mixtures produced with polymer-modified binder than conventional asphalts.

Keywords: hot mix asphalt, SMA, asphalt-rubber, rutting. 


\section{LISTA DE FIGURAS}

Figura 2.1: Esqueleto pétreo de uma mistura SMA e de um CBUQ convencional.........10

Figura 3.1: Curva granulométrica da Faixa C (DNER) .25

Figura 3.2: Curva granulométrica do $\mathrm{SMA}(\mathrm{DMN}=12,5 \mathrm{~mm}$, AASHTO $)$ .25

Figura 4.1: Gráficos da dosagem Marshall para a mistura de referência (CBUQ-AC)....41

Figura 4.2: Gráficos da dosagem Marshall da mistura SMA-AP .42

Figura 4.3: Gráficos da dosagem Marshall da mistura SMA-AB. 43

Figura 4.4: Resultados do ensaio de resistência à tração por compressão diametral.......46

Figura 4.5: Resultados do ensaio de módulo de resiliência .47

Figura 4.6: Gráfico da relação $\mathrm{MR} / \mathrm{RT}$ das misturas asfálticas avaliadas. 48

Figura 4.7: Deformação permanente em trilha de roda - CBUQ-AC

Figura 4.8: Deformação permanente em trilha de roda - SMA-AC.

Figura 4.9: Deformação permanente em trilha de roda - SMA-AP. .52

Figura 4.10: Deformação permanente em trilha de roda - SMA-AB. 52

Figura 4.11: Deformação permanente em trilha de roda - Todas as misturas. 53

Figura 4.12: Gráfico do ensaio de fadiga - CBUQ-AC. .55

Figura 4.13: Gráfico do ensaio de fadiga - SMA-AC .56 
Figura 4.14: Gráfico do ensaio de fadiga - SMA-AP .57

Figura 4.15: Gráfico do ensaio de fadiga - SMA-AB. .57

Figura 4.16: Gráfico do ensaio de fadiga - Todas as misturas. .58 


\section{LISTA DE TABELAS}

Tabela 2.1: Primeira aplicação de SMA em países da Europa e da América do Norte......7

Tabela 2.2: Primeira Faixas granulométricas de SMA na Alemanha .10

Tabela 2.3: Faixas granulométricas de SMA da norma européia .11

Tabela 2.4: Faixas granulométricas de SMA nos EUA (AASHTO MP-8) 11

Tabela 2.5: Misturas Asfálticas SMA ensaiadas por BELIGNI et al (2000). 16

Tabela 3.1: Nome e composição das misturas asfálticas avaliadas. .22

Tabela 3.2: Graduações da Faixa C (DNER) e SMA (AASHTO) 24

Tabela 3.3: Quantidade de agregado para compor um corpo de prova. .24

Tabela 3.4: Quantidade de agregado para compor uma placa de CBUQ-AC. .26

Tabela 3.5: Quantidade de agregado para compor uma placa de SMA .26

Tabela 3.6: Caracterização do CAP 20 (Cimento Asfáltico de Petróleo). 27

Tabela 3.7: Caracterização do asfalto com polímero SBS (Betuflex B 80/60). .28

Tabela 3.8: Caracterização do asfalto-borracha. .28

Tabela 3.9: Temperatura para mistura e compactação das misturas asfálticas. .29

Tabela 3.10: Limites estabelecidos pela especificação DNER ES-313/97. .32

Tabela 3.11: Volume de vazios adotados para seleção do teor de projeto. 32 
Tabela 4.1: Cálculo de $\mathrm{VAG}_{\mathrm{s}}$ .38

Tabela 4.2: Cálculo de vazios do agregado graúdo da mistura compactada com ligante asfáltico $\left(\mathrm{VAG}_{\mathrm{mc}}\right)$

Tabela 4.3: Resultados da dosagem Marshall - CBUQ-AC. 40

Tabela 4.4: Resultados da dosagem Marshall - SMA-AP .40

Tabela 4.5: Resultados da dosagem Marshall - SMA-AB. .40

Tabela 4.6: Resultados do ensaio de resistência de misturas asfálticas compactadas a danos causados por umidade induzida.

Tabela 4.7: Resistência à tração indireta por compressão diametral (MPa). .45

Tabela 4.8: Resultados do ensaio de módulo de resiliência .47

Tabela 4.9: Relação entre o módulo de resiliência e a resistência à tração. 48

Tabela 4.10: Resultados do ensaio de deformação permanente em trilha de roda no simulador de tráfego LCPC. 53

Tabela 4.11: Resultados do ensaio de fadiga - CBUQ-AC .54

Tabela 4.12: Resultados do ensaio de fadiga - SMA-AC. 55

Tabela 4.13: Resultados do ensaio de fadiga - SMA-AP .56

Tabela 4.14: Resultados do ensaio de fadiga - SMA-AB. 56

Tabela 4.15: Parâmetros de fadiga das misturas asfálticas avaliadas. .57

Tabela 4.16: Estrutura hipotética. 59

Tabela 4.17: Resultados da estrutura hipotética 59 


\section{SUMÁRIO}

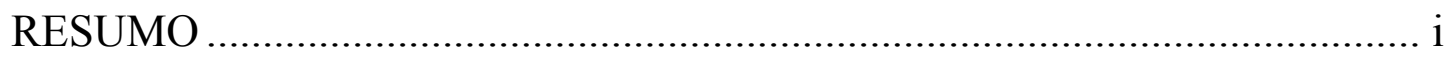

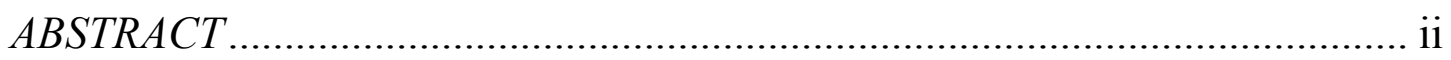

LISTA DE FIGURAS …................................................................................... ii

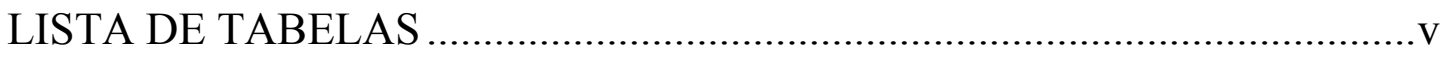

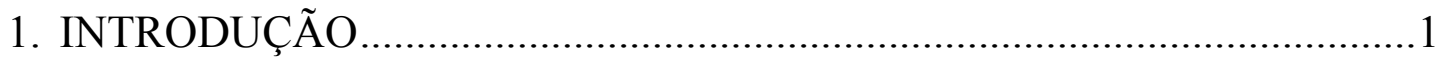

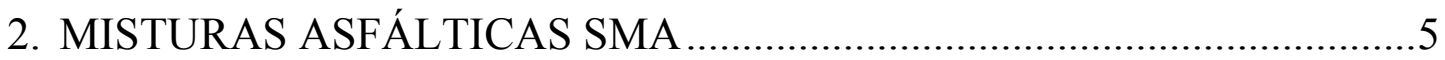

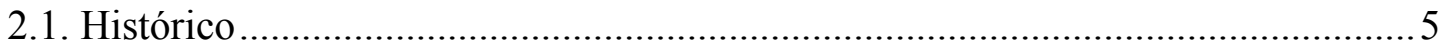

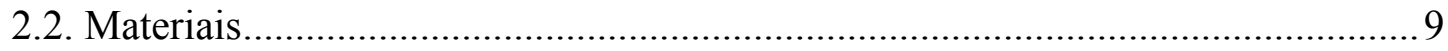

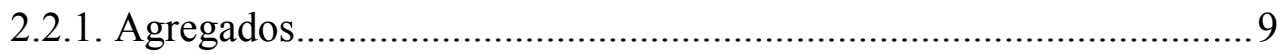

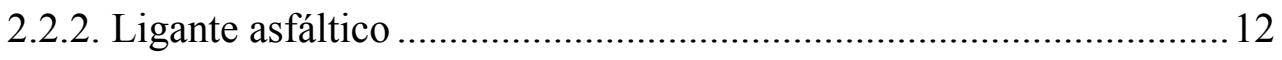

2.2.3. Uso do ligante asfalto-borracha....................................................... 13

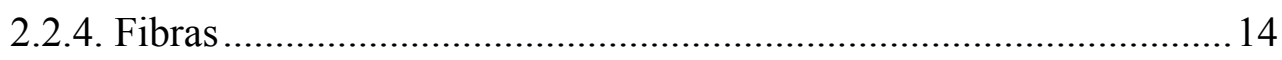

2.3. Características Funcionais............................................................................... 16

2.3.1. Resistência à derrapagem ................................................................. 16

2.3.2. Irregularidade longitudinal ............................................................ 17

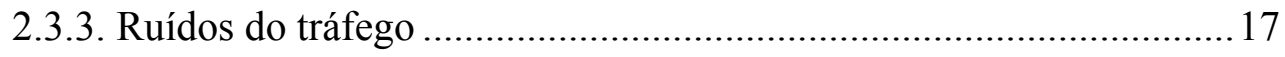

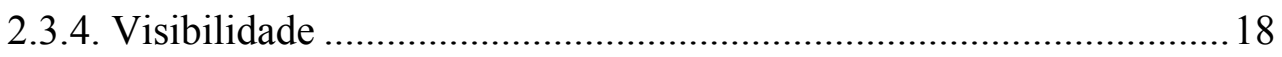

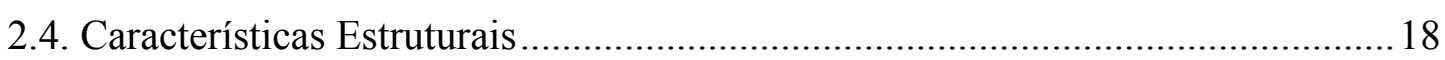

2.4.1. Resistência à deformação permanente em trilha de roda ................... 18

2.4.2. Resistência ao aparecimento e propagação de trincas por fadiga .....20

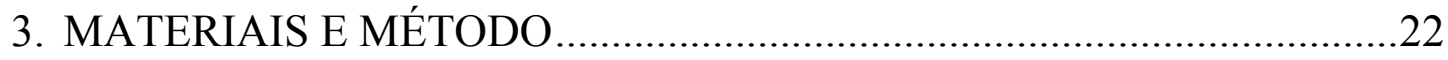

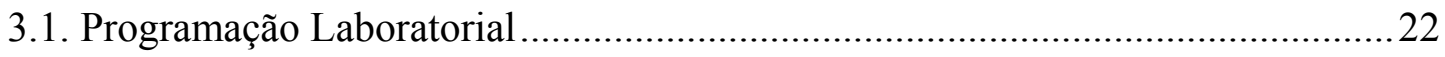

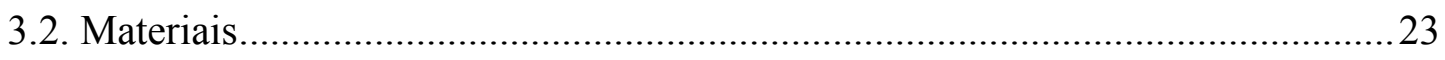

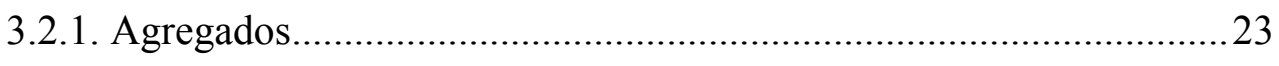

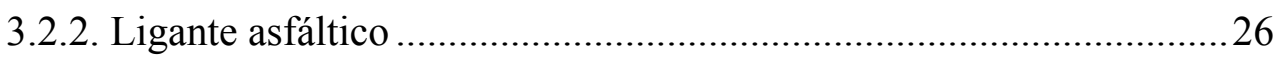

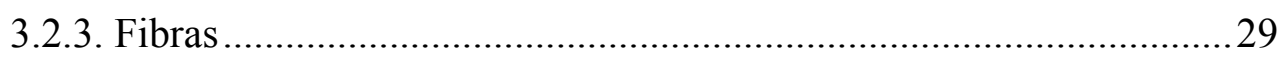

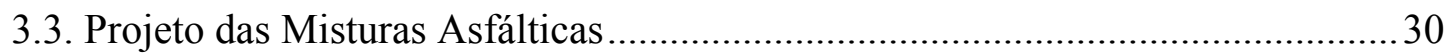




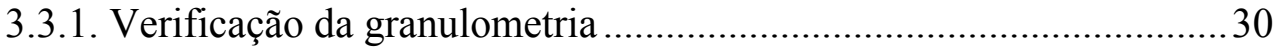

3.3.2. Seleção do teor asfáltico de projeto................................................. 31

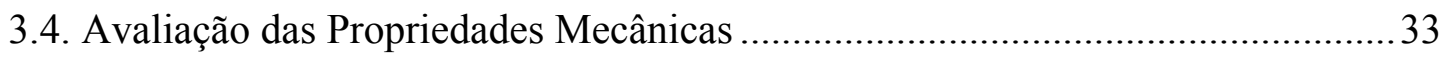

3.4.1. Resistência a danos causados por umidade induzida ....................... 33

3.4.2. Resistência à tração e módulo de resiliência ........................................ 34

3.4.3. Deformação permanente em trilha de roda ....................................... 36

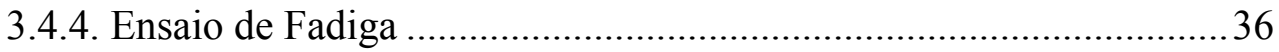

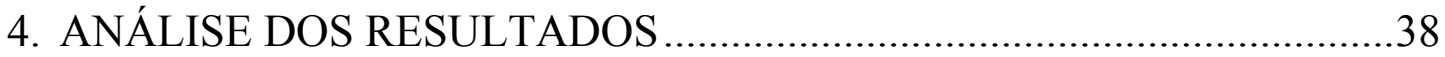

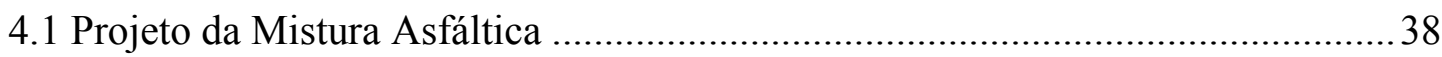

4.1.1 Verificação da granulometria ......................................................... 38

4.1.2 Seleção do teor asfáltico de projeto..................................................39

4.2. Avaliação das Propriedades Mecânicas .................................................................. 44

4.2.1. Resistência a danos causados por umidade induzida ....................... 44

4.2.2. Resistência à tração e módulo de resiliência ....................................... 45

4.2.3. Deformação permanente em trilha de roda ..................................... 49

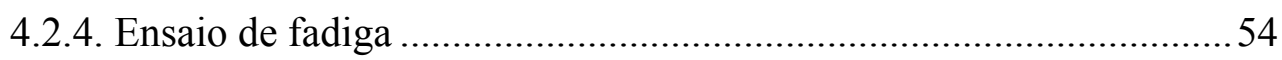

5. CONCLUSÕES E SUGESTÕES PARA TRABALHOS FUTUROS........60

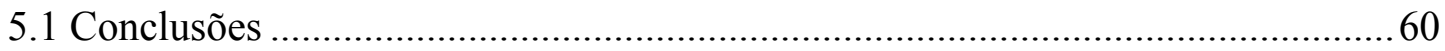

5.2 Sugestões para Trabalhos Futuros........................................................................ 61

REFERÊNCIAS BIBLIOGRÁFICAS_...................................................63 


\section{INTRODUÇÃO}

O Brasil, país de dimensões continentais, depende bastante do transporte rodoviário, uma vez que se trata do modo mais utilizado tanto para o transporte de cargas como de passageiros. A necessidade de uma malha rodoviária capaz de atender ao escoamento da produção e o transporte dos passageiros cresce com o aumento da frota automobilística e com a demanda de tráfego.

A malha rodoviária brasileira encontra-se, em grande parte, numa situação precária, além de ter extensão insuficiente. A reversão desse quadro torna-se cada vez mais difícil devido à diminuição dos investimentos e ao aumento do tráfego. Desse modo, cabe à pesquisa em pavimentação o desenvolvimento de tecnologias que possibilitem a construção de rodovias com uma maior durabilidade, proporcionando um adiamento de uma intervenção de reabilitação e uma diminuição na freqüência de atividades de manutenção.

O pavimento rodoviário é uma estrutura disposta em camadas, construída sobre o subleito e que tem a tarefa de suportar as cargas provenientes da ação do tráfego e fornecer aos usuários segurança, conforto e economia, diretamente relacionados com o estado da superfície de rolamento.

Existem, basicamente, dois tipos de pavimentos rodoviários: rígidos e flexíveis. Nos pavimentos rígidos o revestimento é constituído por placas de concreto de cimento Portland. Nos pavimentos flexíveis o revestimento é, geralmente, formado pela combinação de ligante asfáltico e agregado mineral (mistura asfáltica), podendo conter ainda material de preenchimento (fíler mineral), aditivos etc. $\mathrm{O}$ desempenho das 
misturas asfálticas depende tanto das propriedades de seus componentes individuais quanto da relação entre agregados e ligante.

O SMA (Stone Mastic Asphalt, terminologia mais utilizada na Europa, ou Stone Matrix Asphalt, terminologia mais utilizada nos EUA) é um tipo de mistura asfáltica usada como revestimento de pavimentos rodoviários e de aeroportos, desenvolvida na Alemanha no final da década de 60 .

A mistura asfáltica SMA apresenta granulometria descontínua, composta por uma maior fração (entre $70 \%$ e $80 \%$ ) de agregados graúdos britados de alta qualidade, uma rica massa de ligante/fíler ( $10 \%$ passando na peneira n. $\left.{ }^{\circ} 200\right)$, chamada de argamassa ou mastique, e aproximadamente 4\% de volume de vazios. Essas misturas formam um esqueleto de alta estabilidade devido ao contato pedra-pedra e geralmente consomem de 1 a 1,5\% a mais de cimento asfáltico quando comparadas às misturas de concreto asfáltico convencional.

O acúmulo de deformação permanente nas trilhas de roda é uma das principais formas de deterioração estrutural dos pavimentos flexíveis. Em função do aumento do volume de tráfego e, principalmente, da evolução tecnológica da modalidade rodoviária, que permite que caminhões trafeguem com maiores cargas por eixo, maiores pressões de enchimento dos pneus e novos tipos de pneus e de rodagem (pneus extralargos), a deformação permanente tem merecido toda a atenção no dimensionamento e na dosagem de misturas asfálticas.

A camada de revestimento também está sujeita ao aparecimento e propagação de trincas por fadiga, causadas pelas tensões de tração nas fibras inferiores da camada provenientes das solicitações repetidas do tráfego.

A superfície de rolamento também deve proporcionar economia, conforto e segurança aos usuários. A preocupação com a segurança reside na importância de reduzir o índice de acidentes, crítico em condições de pista molhada, quando há a diminuição da aderência (coeficiente de atrito) e da visibilidade (reflexão da luz e borrifo de água). 
As misturas asfálticas SMA tendem a apresentar bom desempenho quanto à resistência à deformação permanente (devido ao contato pedra-pedra), ao aparecimento de trincas por fadiga e ao desgaste (devido à maior espessura da película de asfalto), quando comparadas às misturas asfálticas convencionais. Além disso, graças a uma macrotextura mais rugosa, as misturas SMA promovem uma melhoria das características funcionais da via, tais como o aumento da resistência à derrapagem e reduções do spray (borrifo de água), da reflexão da luz em condição de pista úmida e do ruído do tráfego.

Com base na experiência da Europa, do Japão e dos Estados Unidos com o uso de misturas asfálticas SMA, observam-se menores custos de manutenção e reabilitação, devido ao melhor desempenho e maior durabilidade dos pavimentos projetados para rodovias com alto volume de tráfego.

As misturas SMA vêm sendo utilizadas na Europa, em mais de 10 países, há mais de 20 anos. Na Alemanha, tornou-se padrão para camadas de revestimento para vias de tráfego pesado. Já nos EUA, houve um grande crescimento do uso de SMA durante a década de 90. Enquanto que, em 1991, apenas 4 estados tinham 50.000 toneladas desse tipo de concreto asfáltico aplicadas, em 1994 o número de estados com SMA cresceu para 23, com mais de 500.000 toneladas aplicadas. Com esse rápido avanço, os organismos rodoviários estaduais, o FHWA (Federal Highway Administration) e a indústria de pavimentação viram a necessidade de se estabelecer métodos e procedimentos para projetar e construir revestimentos asfálticos com SMA, o que acabou acontecendo antes mesmo do final da década de 90.

Posteriormente, o SMA chegou ao Brasil e já vem sendo aplicado em rodovias de alto volume de tráfego no estado de São Paulo, e vem sendo, inclusive, tema de estudo em alguns dos principais centros de pesquisa do país. Essa rápida evolução do uso dessa tecnologia para misturas asfálticas motivou, portanto, o desenvolvimento desta pesquisa.

Os ligantes asfálticos têm grande responsabilidade pelo desempenho dos pavimentos flexíveis, por conta disso foram desenvolvidos aditivos para melhorar as suas propriedades físicas e químicas, o que aumenta a sua resistência ao aparecimento 
de defeitos. Entre os produtos que são adicionados ao cimento asfáltico, destacam-se: melhoradores de adesividade (Dope), agentes rejuvenescedores, polímeros, borracha de pneus moída, etc.

Estudos mostram a necessidade de uso de modificadores nos ligantes para misturas SMA. Devido a um teor asfáltico mais elevado nessas misturas, há uma tendência da ocorrência de escorrimento do ligante. A inibição do escorrimento tem sido conseguida com o uso de fibras. Entre vários tipos (celulose, minerais etc), as de celulose vêm sendo utilizadas com freqüência e têm apresentado bons resultados.

O uso do ligante asfalto-borracha, produzido com borracha de pneus descartados, tem crescido bastante, motivado não apenas pelo seu benefício ambiental, como também pela melhora proporcionada às propriedades mecânicas do concreto asfáltico. Portanto, por se tratar de um tipo de ligante já em uso comercial, torna-se bastante clara a necessidade de se avaliar o seu comportamento quando utilizado em misturas SMA.

Deste modo, esta pesquisa tem por objetivo avaliar se o ligante asfalto-borracha possibilita misturas asfálticas SMA capazes de atender aos valores limites de aceitação. E, através de ensaios de laboratório, avaliar o comportamento das misturas SMA com diferentes tipos de ligante, comparando-as com um concreto asfáltico convencional de granulometria contínua (Faixa C do DNER) utilizado freqüentemente no Brasil.

No capítulo 2 desta dissertação é apresentada uma revisão bibliográfica sobre as misturas SMA, mostrando seu histórico, as particularidades dos materiais e uma breve descrição das suas características funcionais e estruturais.

No capítulo 3 é descrito o método utilizado nesta pesquisa, relatando-se quais os materiais utilizados e os ensaios realizados. O capítulo 4 traz a apresentação e a análise dos resultados obtidos na fase experimental do trabalho. Finalmente, o capítulo 5 apresenta as conclusões e sugestões para trabalhos futuros. 


\section{MISTURAS ASFÁLTICAS SMA}

\subsection{Histórico}

Durante a década de 60, o Ministério de Transportes da Alemanha esteve em busca de uma solução para o problema de deterioração da superfície dos pavimentos asfálticos causada pelo uso de pneus com pregos durante o inverno. Foram utilizadas, inicialmente, misturas asfálticas com maior porcentagem de betume (cerca de 25\%, em peso), que tinham uma alta resistência ao desgaste, porém apresentavam a desvantagem de requerer trabalho manual, serem muito caras e, em algumas ocasiões, produzirem um revestimento não homogêneo.

Optou-se, então, por uma maior quantidade de agregados graúdos, com um teor de ligante em torno de 7\%, mas ocorria o escorrimento do ligante. Depois de várias tentativas, no ano de 1968, uma construtora alemã utilizou fibras como um aditivo estabilizante e, assim, o primeiro revestimento de SMA (com $2 \mathrm{~cm}$ de espessura) foi aplicado em Wilhelmshaven, Alemanha (LANCHAS, 1999).

A utilização de misturas ricas em ligante levou a um aumento das deformações permanentes nas trilhas de roda. Como conseqüência, no final da década de 70, tiveram que ser feitas mudanças conceituais no processo de dosagem com o objetivo de produzir misturas asfálticas mais resistentes à deformação permanente. Devido aos bons resultados obtidos no campo, após os ajustes, a Alemanha publicou a primeira Norma da Mistura Asfáltica SMA em 1984 (BELIGNI et al, 2000). 
Com o sucesso do SMA na Alemanha esse tipo de mistura se espalhou pela Europa. Segundo dados do documento "Heavy Duty Surfaces - The arguments for SMA”, publicado em 1998 pela EAPA (European Asphalt Pavement Association), a Alemanha apresentava em 1996 uma extensão aproximada de $28.600 \mathrm{~km}$ de pista simples, correspondendo a mais de 100 milhões de metros quadrados construídos com SMA, seguida pela Espanha com 69 milhões de metros quadrados, Suécia com 50 milhões de metros quadrados, Holanda com 32 milhões de metros quadrados e França com 18 milhões de metros quadrados.

Outros países também já possuíam expressivas aplicações de SMA, como Dinamarca, Noruega, Polônia, Finlândia, Bélgica, Hungria e Portugal. Na França e Espanha é muito utilizado o concreto asfáltico do tipo BBM (Béton Bitumineux Mince) que é muito similar à mistura asfáltica SMA.

Todos esses países relatam uma experiência muito positiva com misturas SMA, especialmente quanto às características de sua superfície, durabilidade e conforto do rolamento, com ótimo desempenho em pavimentos de tráfego pesado e longa vida em serviço nos pavimentos de baixo volume de tráfego. Porém, a EAPA (1998) ressalta que essas boas experiências são obtidas quando as exigências tecnológicas para esse tipo de mistura são completamente atendidas.

Os primeiros ensaios com misturas SMA realizados na América do Norte foram no Canadá, mais precisamente na Província de Ontário, em dezembro de 1990, registrados por EMERY (1993) e com resultados de deformação permanente melhores que o concreto asfáltico convencional.

A introdução do uso de misturas SMA nos EUA foi recomendada pelos participantes da European Asphalt Study Tour, viagem à Europa de pesquisadores da área de pavimentação dos EUA, realizada no segundo semestre de 1990 e patrocinada por AASHTO, FHWA, NAPA, Asphalt Institute e TRB. Com isso, no início de 1991, o FHWA estabeleceu um grupo de trabalho (Technical Work Group) para desenvolver um manual para materiais e construção de SMA (NAPA, 2002). 
A Tabela 2.1 mostra o início do uso de SMA em diversos países da Europa e da América do Norte.

Tabela 2.1 - Primeira aplicação de SMA em países da Europa e da América do Norte.

\begin{tabular}{|c|c|}
\hline País & Ano \\
\hline Alemanha & 1968 \\
\hline Dinamarca & 1982 \\
\hline Hungria & 1983 \\
\hline Noruega & 1985 \\
\hline França & 1986 \\
\hline Holanda & 1987 \\
\hline Suécia & 1988 \\
\hline Canadá & 1990 \\
\hline República Tcheca & 1991 \\
\hline Itália & 1991 \\
\hline EUA & 1991 \\
\hline Portugal & 1994 \\
\hline Reino Unido & 1994 \\
\hline Fonte: EAPA 1998. \\
\hline
\end{tabular}

Fonte: EAPA, 1998.

Em meados de 1991, cinco estados americanos (Geórgia, Indiana, Michigan, Missouri e Wisconsin) fizeram os primeiros trechos experimentais com SMA nos EUA, totalizando algo em torno de 50.000 toneladas de concreto asfáltico aplicado, ainda seguindo uma receita alemã para projetar estas misturas. Os resultados iniciais mostraram a dificuldade de se obter uma dosagem ótima do teor de ligante, porém os resultados obtidos foram muito satisfatórios.

Já em 1994, 23 estados americanos possuíam trechos desse tipo de mistura asfáltica, totalizando mais de 500.000 toneladas. Neste mesmo ano, em agosto, o NAPA publicou Guidelines for Materials, Production and Placement of Stone Matrix Asphalt, o primeiro manual de SMA dos EUA (NAPA, 2002). 
Em julho de 1997, pelo menos 28 estados americanos haviam construído mais de 100 projetos de SMA, totalizando mais de três milhões de toneladas de concreto asfáltico (NAPA, 2002). Em 1995, um procedimento padrão de dosagem de misturas asfálticas foi publicado pelo NCAT (National Center for Asphalt Technology) para o TRB (Transportation Research Board), sob o Projeto de Pesquisa NCHRP 9-8 (National Cooperative Highway Research Program). Essa versão do procedimento era aplicável a SMA com diâmetro máximo nominal de 19 mm.

Em 1999, BROWN e COOLEY JR., do NCAT, publicaram o "NCHRP Report 425 - Designing Stone Matrix Asphalt Mixtures for Rut-Resistent Pavements", que inclui um método para dosagem de misturas, um guia para construção e procedimentos de controle de qualidade de SMA. Esse documento abrange quase todos os diâmetros máximos nominais ( $25 \mathrm{~mm}, 19 \mathrm{~mm}, 12,5 \mathrm{~mm}, 9,5 \mathrm{~mm}$ e 4,75 mm), não contemplando o diâmetro máximo nominal de $37,5 \mathrm{~mm}$, utilizado pela especificação Superpave. Este relatório serviu de base para duas normas da AASHTO: MP 8 - Specification for Designing SMA e PP 41 - Practice for Designing SMA.

Em 1998, a Alemanha adotou o uso do SMA para rodovias de tráfego pesado em substituição ao concreto asfáltico de granulometria densa (ZTV Asphalt - StB 94, 1998) e, em 2001, uma nova norma foi publicada para as misturas SMA da Alemanha (ZTV Asphalt - StB 01, 2001).

BOLZAN (2000) relata o uso de uma mistura asfáltica SMA numa das principais rodovias da Argentina (Ricchieri), com tráfego de 120.000 veículos por dia. Os resultados mostram um revestimento resistente ao acúmulo de deformação permanente nas trilhas de roda, confortável e seguro.

Em 2000, o revestimento asfáltico do tipo SMA foi utilizado no recapeamento do pavimento do Autódromo de Interlagos, São Paulo, para a etapa do Brasil da temporada de Fórmula 1. Os estudos sobre a tecnologia dessas misturas asfálticas no Brasil ainda estão se iniciando, onde, cada vez mais, este tipo de concreto asfáltico vem sendo aplicado em trechos de rodovias, principalmente no estado de São Paulo. BELIGNI et al (2000), REIS (2002) e CHAVES et al. (2002) apresentam resultados de alguns desses estudos. 


\subsection{Materiais}

Em relação a um CBUQ (concreto betuminoso usinado a quente) convencional, uma mistura asfáltica SMA apresenta características diferentes de granulometria, teor asfáltico e aditivos estabilizadores.

\subsubsection{Agregados}

Num pavimento asfáltico as cargas aplicadas são, em grande parte, suportadas pelos agregados, que devem atender exigências mínimas de qualidade. Além disso, a graduação do agregado também condiciona o desempenho em serviço.

As misturas asfálticas SMA possuem uma curva granulométrica descontínua, onde prevalecem os agregados graúdos, com uma porcentagem em torno de 70\%. Há, portanto, um maior contato pedra-pedra, sendo recomendado o uso de agregados britados de alta qualidade com uma boa microtextura e sempre virgens, ou seja, não podem ser provenientes de revestimentos reciclados. Na maioria dos países da Europa é exigido o uso de agregados $100 \%$ britados.

Para garantir a estabilidade da mistura, tem-se uma argamassa (mastique) rica em fíler e betume. Nas misturas SMA, o teor de fíler (material passado na peneira 200) situa-se entre $8 \%$ e $13 \%$, um pouco superior ao de um concreto asfáltico convencional.

A Figura 2.1 dá uma idéia do esqueleto pétreo de uma mistura SMA com o mastique envolvendo os agregados e proporcionando estabilidade, comparado a um concreto asfáltico convencional de distribuição granulométrica contínua.

A granulometria de uma mistura SMA é, normalmente, determinada pelo diâmetro máximo nominal (uma abertura de peneira maior do que a primeira peneira que retém mais de $10 \%$ ) e, às vezes, pela peneira de ponto de quebra, definida como o diâmetro da peneira que separa as proporções relativas dos agregados graúdos e finos. Na Europa, os tipos de SMA mais utilizados são 0/5 (agregados com diâmetro inferior a $5 \mathrm{~mm}), 0 / 6,0 / 8$ e 0/11, sendo este último o mais comumente usado para vias de tráfego pesado. 


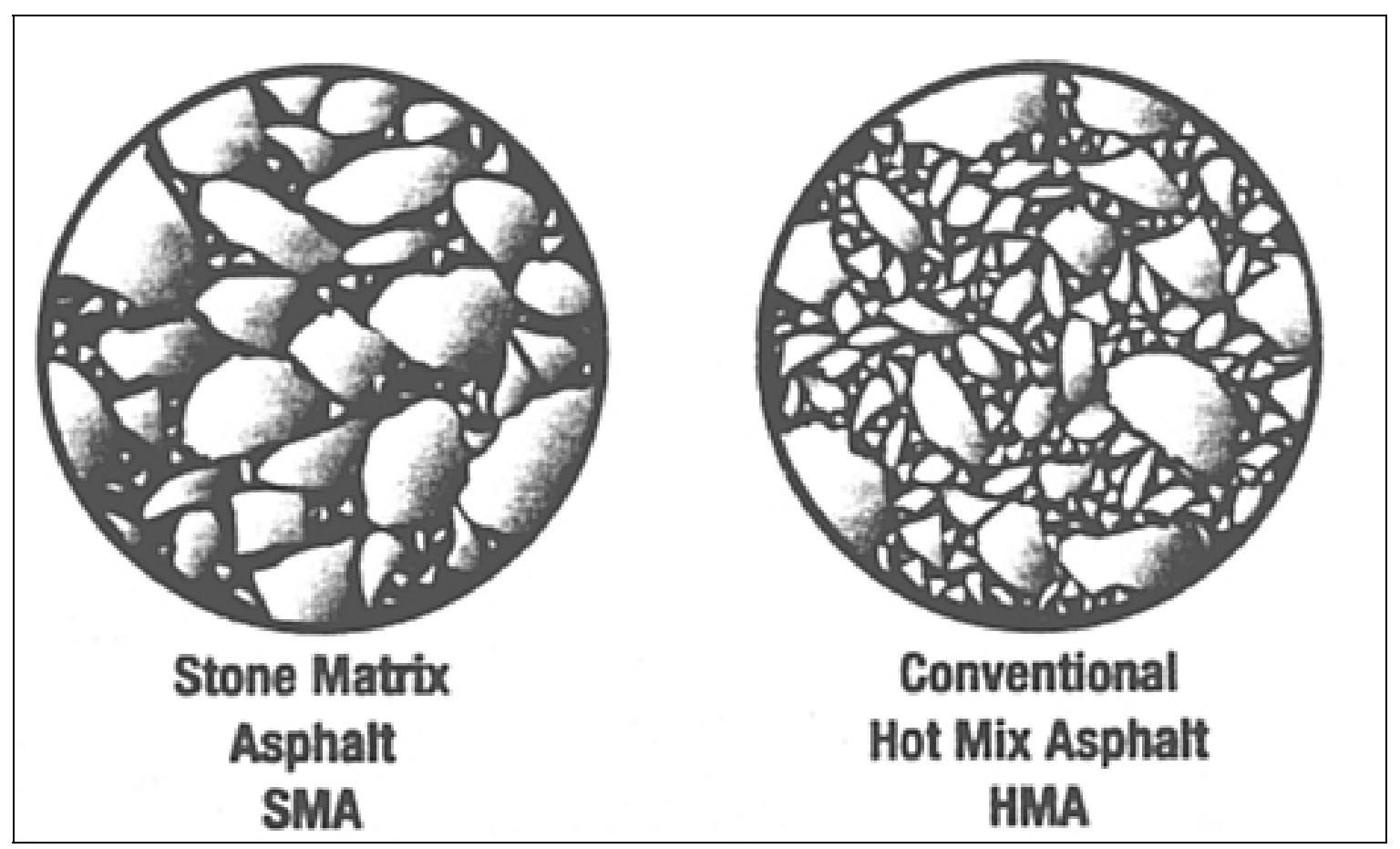

Figura 2.1 - Esqueleto pétreo de uma mistura SMA e de um CBUQ convencional. Fonte: NAPA, 2002.

Nos EUA, as faixas granulométricas têm como diâmetro máximo nominal (DMN) do agregado: $25 \mathrm{~mm}, 19 \mathrm{~mm}, 12,5 \mathrm{~mm}, 9,5 \mathrm{~mm}$ e $4,75 \mathrm{~mm}$ e as porcentagens passadas são em volume. As Tabelas 2.2, 2.3 e 2.4 ilustram a granulometria utilizada nas misturas SMA na Alemanha, Europa e EUA.

Tabela 2.2 - Faixas granulométricas de SMA na Alemanha.

\begin{tabular}{|c|c|c|c|c|}
\hline \multirow{2}{*}{$\begin{array}{c}\text { Diâmetro de } \\
\text { abertura (mm) }\end{array}$} & \multicolumn{4}{|c|}{ Porcentagem passando em peso } \\
\cline { 2 - 5 } & $\mathbf{0 / 1 1} \mathbf{~ S}$ & $\mathbf{0 / 8} \mathbf{S}$ & $\mathbf{0 / 8}$ & $\mathbf{0 / 5}$ \\
\hline 11,2 & $90-100$ & 100 & 100 & - \\
\hline 8,0 & $30-60$ & $90-100$ & $100-90$ & 100 \\
\hline 5,0 & $30-40$ & $30-45$ & $30-55$ & $90-100$ \\
\hline 2,0 & $20-25$ & $20-25$ & $20-30$ & $30-40$ \\
\hline 0,090 & $9-13$ & $10-13$ & $8-13$ & $8-13$ \\
\hline
\end{tabular}

Fonte: EAPA, 1998. 
Tabela 2.3 - Faixas granulométricas de SMA da norma européia.

\begin{tabular}{|c|c|c|c|c|c|c|}
\hline \multirow{2}{*}{$\begin{array}{c}\text { Diâmetro de } \\
\text { abertura } \\
(\mathbf{m m})\end{array}$} & \multicolumn{5}{|c|}{ Porcentagem passando em peso } \\
\hline & D 16 & D 14 & D 11 & D 10 & D 8 & D 6 \\
\hline 22,4 & 100 & & & & & \\
\hline 20,0 & & 100 & & & & \\
\hline 16,0 & $90-100$ & & 100 & & & \\
\hline 14,0 & & $90-100$ & & 100 & & \\
\hline 11,2 & $45-75$ & & $90-100$ & & 100 & \\
\hline 10,0 & & $50-75$ & & $90-100$ & & \\
\hline 8,00 & $25-40$ & & $45-75$ & & $90-100$ & 100 \\
\hline 6,30 & & $20-35$ & & $30-50$ & & \\
\hline 5,60 & & & & & & $90-100$ \\
\hline 4,00 & $20-35$ & & $25-40$ & & $25-45$ & \\
\hline 2,00 & $15-30$ & $15-30$ & $20-30$ & $20-30$ & $20-30$ & $30-40$ \\
\hline 0,063 & $8-12$ & $8-12$ & $8-12$ & $8-12$ & $8-12$ & $8-12$ \\
\hline
\end{tabular}

Fonte: EAPA, 1998.

Tabela 2.4 - Faixas granulométricas de SMA nos EUA (AASHTO MP-8).

\begin{tabular}{|c|c|c|c|c|c|}
\hline \multirow{2}{*}{$\begin{array}{c}\text { Diâmetro de } \\
\text { abertura (mm) }\end{array}$} & \multicolumn{5}{|c|}{ Porcentagem Passando em volume } \\
\cline { 2 - 6 } & $\mathbf{2 5} \mathbf{~ m m}$ & $\mathbf{1 9} \mathbf{~ m m}$ & $\mathbf{1 2 , 5} \mathbf{~ m m}$ & $\mathbf{9 , 5} \mathbf{~ m m}$ & $\mathbf{4 , 7 5} \mathbf{~ m m}$ \\
\hline 37,5 & 100 & - & - & - & - \\
\hline 25,4 & $90-100$ & 100 & - & - & - \\
\hline 19,1 & $30-86$ & $90-100$ & 100 & - & - \\
\hline 12,7 & $26-63$ & $50-74$ & $90-100$ & 100 & - \\
\hline 9,52 & $24-52$ & $25-60$ & $26-78$ & $90-100$ & 100 \\
\hline 4,76 & $20-28$ & $20-28$ & $20-28$ & $26-60$ & $90-100$ \\
\hline 2,36 & $16-24$ & $16-24$ & $16-24$ & $20-28$ & $28-65$ \\
\hline 1,18 & $13-21$ & $13-21$ & $13-21$ & $13-21$ & $22-36$ \\
\hline 0,60 & $12-18$ & $12-18$ & $12-18$ & $12-18$ & $18-28$ \\
\hline 0,30 & $12-15$ & $12-15$ & $12-15$ & $12-15$ & $15-22$ \\
\hline 0,074 & $8-10$ & $8-10$ & $8-10$ & $8-10$ & $12-15$ \\
\hline
\end{tabular}




\subsubsection{Ligante asfáltico}

As misturas SMA possuem uma película de ligante asfáltico mais espessa, com teor entre $1 \%$ e $1,5 \%$ superior ao de concretos asfálticos convencionais, com o objetivo de evitar um desgaste dos agregados causado pelo contato pedra-pedra. O teor de ligante mais elevado faz com que seja necessário o uso de aditivos, buscando um aumento na consistência do ligante asfáltico. Esses aditivos em geral são polímeros e/ou fibras.

Na Europa, geralmente usa-se o ligante asfáltico B60 [penetração entre 50 e 70 $(1 / 10 \mathrm{~mm})$ ], sendo o ligante B80 [penetração entre 70 e $100(1 / 10 \mathrm{~mm})$ ] utilizado em vias de baixo volume de tráfego. Para rodovias de tráfego pesado, ligantes modificados são exigidos ou, pelo menos, aconselhados. No sul da Europa há uma preferência pelo uso de asfalto modificado por polímero nas misturas SMA, especialmente em combinação com alto volume de vazios e baixo teor de ligante. Existem países, como Itália e Portugal, por exemplo, em que o uso de asfalto com polímero é obrigatório quando se trata de uma mistura SMA (EAPA, 1998).

O uso de ligantes modificados é justificado por algumas razões: aumento da resistência à deformação permanente, aumento da vida útil do revestimento e redução da necessidade de inibidores de escorrimento, embora este ainda seja necessário para algumas misturas asfálticas.

Os cimentos asfálticos modificados por polímeros apresentam maior viscosidade sob elevadas temperaturas, quando comparados aos cimentos asfálticos convencionais, o que contribui para a redução das deformações visco-plásticas da mistura asfáltica.

No Brasil, REIS (2002) utilizou como ligantes asfálticos um CAP 20 (material de referência) e dois tipos de asfaltos modificados por polímero, denominados AMP-1 (3\% a $4 \%$ de polímero SBS) e AMP-2 (5\% a $6 \%$ de polímero SBS). Este último apresentou melhores resultados nos ensaios de resistência à deformação permanente realizados em simulador de tráfego LCPC (Laboratorie Central des Ponts et Chaussées) e de resistência à tração por compressão diametral. 


\subsubsection{Uso do ligante asfalto-borracha}

Ao mesmo tempo em que ocorre o crescimento da frota de veículos, cresce também o número de pneus descartados. Este tipo de resíduo é bastante problemático do ponto de vista ambiental, o que traz a necessidade de soluções para a sua disposição final.

A borracha de pneus usados tem sido utilizada na pavimentação e, particularmente, nas misturas asfálticas. Nesse caso, o seu uso se dá de duas maneiras: o "processo seco", quando as partículas de borracha triturada substituem parte dos agregados na mistura e, após a adição do ligante, formam o concreto asfáltico modificado com adição de borracha; e o "processo úmido", onde a borracha de pneus moída é incorporada ao cimento asfáltico antes da adição do agregado, formando o ligante asfalto-borracha.

Os objetivos da adição de borracha de pneus em ligantes asfálticos são minimizar o problema da disposição de pneus usados e melhorar o desempenho dos pavimentos mediante aumento da rigidez a elevadas temperaturas (reduzindo a deformação permanente nas trilhas de roda), aumento da flexibilidade (retardando o aparecimento de trincas) e aumento da impermeabilização proporcionada pelos revestimentos asfálticos.

O obstáculo ao emprego dessa tecnologia tem sido, principalmente, de origem econômica, pois a trituração dos pneus ainda representa um custo relativamente alto. Porém, à medida que os trabalhos de pesquisa apresentarem resultados sobre a viabilidade técnica e a sociedade se conscientizar do elevado custo ambiental da disposição de pneus inservíveis, certamente o uso do ligante asfalto-borracha se disseminará.

EMERY (1996) relata o uso de ligante asfalto-borracha em uma rodovia próxima a Toronto, na província de Ontário, em julho de 1990. Não houve problemas de aplicação e compactação e o desempenho, particularmente em termos de redução de trincas transversais, foi superior ao do trecho experimental de controle. 
Entre 1989 e 1990, foram executados três trechos experimentais na Flórida, com utilização de ligante asfalto-borracha (CHOUBANE et al., 1999). Os trechos foram avaliados periodicamente durante dez anos, constatando-se que o ligante asfaltoborracha resultou em melhoria de desempenho do revestimento asfáltico com relação à ocorrência de trincas e panelas.

Baseado nessa pesquisa, o FDOT (Florida Department of Transportation) iniciou a implementação de especificações para o uso de borracha de pneus moída nas misturas asfálticas, o que veio a se concretizar em 1994, com perspectivas de utilização, em pavimentação asfáltica, de aproximadamente um quinto dos pneus descartados anualmente.

Pesquisa realizada por ODA (2000) concluiu que o ligante asfalto-borracha pode ser benéfico aos pavimentos, melhorando as propriedades de resistência ao acúmulo de deformação permanente (maior rigidez a elevadas temperaturas) e de resistência à formação de trincas por fadiga (maior elasticidade). Além disso, as amostras ensaiadas também apresentaram suficiente resistência à formação de trincas por contração térmica.

\subsubsection{Fibras}

Fibras são adicionadas às misturas SMA para se evitar o escorrimento do ligante durante o processo de construção (produção e aplicação da mistura), especialmente durante o transporte. As fibras, geralmente, não têm influência sobre o desempenho da mistura depois da compactação.

Pelo fato de as fibras impedirem o escorrimento do ligante durante $\mathrm{o}$ armazenamento, transporte e aplicação do SMA, o uso delas possibilita um maior teor de ligante, o que gera uma película mais espessa ao redor do agregado, retardando a oxidação, a penetração de umidade e a separação dos agregados. Essas vantagens servem para proteger o concreto asfáltico do desgaste.

As fibras podem ser de vidro ou celulose e são fornecidas soltas ou peletizadas. As fibras de celulose peletizadas podem ser facilmente adicionadas à mistura asfáltica e já são de uso freqüente em misturas SMA no estado de São Paulo, com bons resultados, 
além de se ter registro de sucesso em pesquisas realizadas nos EUA (estados de Michigan, Wisconsin e Flórida) e no Canadá (Ontário). No processo de mistura de um concreto asfáltico, as fibras são adicionadas à mistura seca, com os agregados já aquecidos. Com a colocação do ligante e início do processo de mistura, as fibras se soltam e se espalham por toda a mistura. $\mathrm{O}$ asfalto que as envolve mistura-se ao ligante sem qualquer problema.

Segundo LANCHAS (1999), as fibras de celulose são o melhor veículo para o betume, pois são quimicamente inertes, resistentes a ácidos diluídos e soluções alcalinas e totalmente inócuas do ponto de vista fisiológico e toxicológico. Além disso, são produzidas de fontes renováveis.

Em muitos casos, a determinação do teor de fibras se baseia na experiência. Várias publicações sugerem o teor de $0,3 \%$ a $0,5 \%$. Contudo, existem ensaios que verificam se as fibras são suficientes para inibir o escorrimento do ligante, como os utilizados, por exemplo, na Holanda, na Alemanha (Schellenberg test) e nos EUA, onde ensaio é o AASHTO T-305/97 (Draindown Sensivity).

Pesquisa realizada por BROWN (1993) mostra que a presença ou teor de fibras não altera as propriedades volumétricas e mecânicas das misturas asfálticas SMA. Foram produzidas misturas asfálticas SMA com diferentes teores de fibras de celulose $(0,0 \%, 0,2 \%, 0,3 \%$ e $0,4 \%)$, avaliadas através de propriedades volumétricas (volume de vazios e vazios do agregado mineral) e mecânicas [GSI (gyratory shear index), tensão de cisalhamento do GTM (gyratory test machine) e creep confinado]. A variação do teor de fibras não teve influência em nenhuma das propriedades avaliadas, contribuindo apenas para a inibição do escorrimento de ligante.

BELIGNI et al (2000), no entanto, utilizou um teor de fibras mais elevado e seus resultados mostraram que o excesso de fibras piorou as propriedades mecânicas da mistura (resistência à tração por compressão diametral e à deformação permanente no simulador de tráfego LCPC), como mostra a Tabela 2.5. 
Tabela 2.5 - Misturas Asfálticas SMA ensaiadas por BELIGNI et al (2000).

\begin{tabular}{|c|c|c|}
\hline $\begin{array}{c}\text { Teor de } \\
\text { fibras }\end{array}$ & $\begin{array}{c}\text { Deformação } \\
\text { Permanente }\end{array}$ & $\begin{array}{c}\text { Resistência à } \\
\text { tração (MPa) }\end{array}$ \\
\hline $0,0 \%$ & $13,0 \%$ & 0,86 \\
\hline $0,3 \%$ & $5,5 \%$ & 1,04 \\
\hline $0,5 \%$ & $5,5 \%$ & 0,95 \\
\hline $0,7 \%$ & $8,5 \%$ & 0,78 \\
\hline
\end{tabular}

Tendo em vista que uma pequena variação no teor de fibras não traz grande conseqüência nas propriedades mecânicas, apenas no escorrimento, e que, quando se varia de forma exagerada (por excesso ou ausência), ocorre influência nas propriedades mecânicas, a dosagem do teor de fibras tem como objetivo a redução dos custos, buscando uma quantidade mínima para impedir o escorrimento.

\subsection{Características Funcionais}

Além de ter uma finalidade estrutural, por suportar as cargas provenientes do tráfego, a camada de revestimento do pavimento também deve atender às condições de segurança e conforto. Por conta disso, para escolha de uma mistura asfáltica usada como superfície de rolamento devem ser consideradas características funcionais: resistência à derrapagem (coeficiente de atrito), irregularidade, nível de ruído e visibilidade.

\subsubsection{Resistência à derrapagem}

A resistência à derrapagem está intimamente atrelada à segurança dos usuários que trafegam sobre o pavimento. Um revestimento asfáltico com boa resistência à derrapagem dependerá de dois fatores principais: tipo do agregado (microtextura) e textura da superfície (macrotextura).

As misturas SMA têm uma macrotextura mais rugosa, ocasionada pela ausência de agregados médios. Vários estudos têm indicado que o desempenho do SMA (em relação à macrotextura) será melhor ou igual que o de concretos asfálticos convencionais com o mesmo tipo de agregado. 
Uma boa macrotextura é importante para a dispersão (escoamento) da água superficial na interface pneu-pavimento e na provisão de uma maior aderência da borracha dos pneus dentro das depressões superficiais do revestimento.

Quando novo, um revestimento com mistura SMA tem um filme de ligante mais espesso na superfície, por isso é necessário um certo período de tráfego para desgastar o filme do ligante e desenvolver uma boa microtextura. Em muitos países da Europa há a prática de aplicação de areia proveniente de britagem $(0-2 \mathrm{~mm})$ para evitar uma espera pela ação do tráfego e trazer segurança ao usuário já no início da vida em serviço da camada.

\subsubsection{Irregularidade longitudinal}

A irregularidade de uma camada de rolamento causa desconforto aos motoristas, portanto é essencial que o pavimento tenha uma qualidade de rolamento aceitável. Isto dependerá dos cuidados nas etapas de lançamento e compactação do revestimento e de seu desempenho ao longo da vida em serviço

Nas misturas asfálticas SMA, devido à forte estrutura dos agregados, o acabamento inicial da pavimentadora tem maior influência sobre a qualidade do rolamento, limitando o efeito da compactação adicional pelo rolo. Conseqüentemente, uma mistura asfáltica SMA pode alcançar níveis maiores de conforto se comparada a um concreto asfáltico convencional (EAPA, 1998). A qualidade de rolamento de revestimentos asfálticos tipo SMA também foi considerada satisfatória em pesquisas publicadas por CHAVES et al. (2002) e BOLZAN (2000).

\subsubsection{Ruídos do tráfego}

Um dos ganhos apresentados pelas misturas SMA nos estudos realizados foi a redução dos ruídos do tráfego, ocasionando maior conforto aos usuários, além do benefício ambiental (redução da poluição sonora). Isto se explica pelo fato de que a macrotextura mais rugosa tem maior número de faces e arestas e, conseqüentemente, uma maior superfície para absorção do som.

Trabalhos da EAPA (1998) mostram que misturas SMA produzem menos ruído que concretos asfálticos convencionais, em medições feitas na Itália e no Reino Unido. 
Pesquisa realizada pelo WisDOT (Wisconsin Department of Transportation), em 1998, mediu ruídos em rodovias e as misturas SMA tiveram resultados mais satisfatórios que o concreto asfáltico convencional.

\subsubsection{Visibilidade}

Uma macrotextura mais rugosa significa mais faces não paralelas à superfície da camada de rolamento, resultando numa redução do reflexo da luz proveniente dos veículos e no borrifo de água (spray) dos pneus, aumentando, assim, a visibilidade e trazendo mais segurança para os usuários.

\subsection{Características Estruturais}

Além das características funcionais que um revestimento deve ter, existe a necessidade de suportar os esforços aos quais a camada é submetida. Uma mistura asfáltica deve possuir condições de evitar dois importantes defeitos estruturais a que todo pavimento está sujeito: deformação permanente nas trilhas de roda e trincas por fadiga.

\subsubsection{Resistência à deformação permanente em trilha de roda}

A deformação permanente nas trilhas de roda decorre do acúmulo de pequenas deformações plásticas sofridas pelo pavimento a cada solicitação do tráfego ao longo da vida em serviço.

A ocorrência acentuada desse defeito tem duas razões principais: mau dimensionamento das camadas do pavimento, quando o acúmulo de deformações situase no subleito; deformações nas misturas asfálticas com baixa resistência ao cisalhamento, que depende da susceptibilidade térmica do ligante asfáltico e do esqueleto dos agregados minerais.

Um revestimento asfáltico com deformação permanente excessiva proporciona um aumento na irregularidade longitudinal (qualidade do rolamento) e condições para acúmulo de água na superfície do pavimento, tornando-se um ponto de risco para aquaplanagem. 
As misturas asfálticas SMA têm apresentado uma maior resistência à deformação permanente quando comparadas aos concretos asfálticos convencionais, como mostram várias pesquisas realizadas no Brasil, na Europa e na América do Norte.

A resistência à deformação permanente em trilhas de roda pode ser medida de várias formas em laboratório. Uma das formas mais simples é o ensaio de fluência sob carga axial (creep estático), de uso comum no Brasil, ou também sob carga axial repetida (creep dinâmico), nesse caso aplica-se uma carga vertical cíclica (de forma pneumática) em um corpo de prova de concreto asfáltico, geralmente moldado no compactador Marshall. O ensaio de compressão triaxial cíclica, pouco comum no Brasil, consiste em submeter um corpo de prova a uma carga confinante constante, enquanto uma carga vertical é aplicada de forma cíclica.

Vários equipamentos foram desenvolvidos para simular o efeito do tráfego em laboratório. Normalmente são usados pneus de borracha que rolam sobre placas compactadas em laboratório ou extraídas do próprio pavimento, no campo. O mais tradicional é o equipamento francês (LCPC), porém há vários equipamentos desenvolvidos em organismos rodoviários, como por exemplo na Província de Ontário (Canadá), no Estado da Geórgia (EUA), na cidade de Hamburgo (Alemanha) etc.

A grande maioria realiza o ensaio a temperatura elevada, entre $50^{\circ} \mathrm{C}$ e $60^{\circ} \mathrm{C}$, e registra o afundamento em alguns pontos da superfície da placa. Os resultados da deformação podem ser expressos em termos de porcentagem ou em milímetros. A inclinação da reta do logaritmo da deformação em função do logaritmo do número de ciclos também é um parâmetro de análise.

BELIGNI et al. (2000) ensaiaram misturas SMA para serviços de recapeamento da pista do Autódromo de Interlagos no simulador de tráfego LCPC do LTP-EPUSP e obtiveram uma porcentagem de afundamento de 5,5\%, bem próximo do limite especificado pela norma francesa $(5,0 \%)$ para camadas de rolamento submetidas a tráfego pesado. Nas misturas sem fibras e com CAP convencional, obtiveram um desempenho insatisfatório, acima de $10 \%$, limite para rodovias de tráfego leve a médio. Foi observado escorrimento do ligante, que ficou concentrado na parte inferior das placas. 
Relatório da EAPA (1998) apresenta resultados de vários ensaios de compressão triaxial com concreto asfáltico convencional com CAP e misturas SMA com CAP e ligante modificado por polímero, realizados na Holanda. Usando o concreto asfáltico convencional como referência, a melhora na resistência à deformação permanente do SMA com um CAP de mesma penetração foi de 4 vezes e quanto à mistura SMA com asfalto modificado por polímero, a melhora chegou a ser de 5 a 10 vezes. Ainda no mesmo documento, ensaios realizados nos EUA usando um simulador de tráfego em laboratório mostraram que o SMA teve um melhor desempenho, da ordem de $30 \%$ (com asfalto-borracha) e de 60 a $300 \%$ (com asfalto modificado por polímero).

Na pesquisa de EMERY et al. (1993), placas de mistura SMA e CBUQ convencional, extraídas de pavimentos, foram ensaiadas no MTO Wheel Tracking Test. Das duas misturas estudadas, apenas o afundamento da mistura SMA (2,6 mm) ficou abaixo do máximo aceitável $(5,0 \mathrm{~mm})$ para misturas resistentes à deformação permanente estabelecido pelo MTO (Ontario Ministry of Transportation).

\subsubsection{Resistência ao aparecimento e propagação de trincas por fadiga}

Associada à flexibilidade das camadas de base e sub-base granulares, a repetição das solicitações de tráfego provoca o trincamento por fadiga na camada de revestimento asfáltico. No Brasil, o primeiro estudo em laboratório relativo às propriedades de fadiga das misturas asfálticas foi publicado na $16^{\mathrm{a}}$ Reunião Anual de Pavimentação, em Recife-PE, por PREUSSLER, PINTO \& MEDINA (1981).

Por ter um maior teor de ligante e, conseqüentemente, uma película asfáltica mais espessa, a mistura SMA tem apresentado uma boa resistência ao aparecimento e propagação de trincas por fadiga, causadas pela repetição da ação do tráfego ao longo da vida em serviço do pavimento.

Segundo SCHMIEDLIN (1998), resultados de pesquisas em trechos construídos no estado de Wisconsin (EUA) indicaram, de uma maneira geral, que as misturas SMA tiveram desempenho melhor que o concreto asfáltico convencional. 
A capacidade de uma mistura asfáltica em resistir ao aparecimento de trincas por fadiga pode ser avaliada de várias formas. Um delas é o ensaio da viga, que submete uma viga de concreto asfáltico à flexão, de forma cíclica, e mede o deslocamento em alguns pontos da mesma. Existe também o ensaio francês, em que uma peça prismática de concreto asfáltico é engastada em uma extremidade, enquanto se aplica uma carga repetida na outra extremidade, perpendicularmente à maior dimensão do corpo de prova.

O ensaio de fadiga utilizando corpos de prova cilíndricos submetidos à compressão diametral com carga repetida tem uma maior facilidade de execução, pois pode ser realizado no mesmo equipamento do módulo de resiliência e os corpos de prova são moldados no compactador Marshall.

Nesse experimento, o ensaio é realizado com várias cargas, que correspondem a frações da resistência à tração da mistura. Dessa forma, repete-se a aplicação da carga até que se atinja a ruptura do corpo de prova, registrando-se o número de repetições correspondente. Com esses dados traça-se uma curva de fadiga destacando-se que embora não se possa fazer uma correlação direta com a vida em serviço da mistura, é possível fazer a comparação com outras misturas ensaiadas do mesmo modo. 


\section{MATERIAIS E MÉTODO}

\subsection{Programação Laboratorial}

Esta pesquisa tem por objetivo avaliar, com base em resultados de ensaios de laboratório, misturas asfálticas SMA com diferentes tipos de ligante: CAP 20, sem modificador; asfalto modificado por polímero SBS; e, particularmente, asfalto-borracha. É feita a comparação com uma mistura de referência, de granulometria contínua (Faixa C do DNER) e com ligante convencional (CAP 20, sem modificador).

As quatro misturas asfálticas ensaiadas são apresentadas na Tabela 3.1. Foram realizados os seguintes ensaios de laboratório:

- $\quad$ Módulo de resiliência por compressão diametral;

- Resistência à tração indireta por compressão diametral;

- $\quad$ Ensaio de fadiga por compressão diametral;

- Deformação permanente no simulador de tráfego tipo LCPC.

Tabela 3.1 - Nome e composição das misturas asfálticas avaliadas.

\begin{tabular}{|c|c|c|}
\hline Nome & Granulometria & Tipo de ligante \\
\hline CBUQ-AC & Faixa C (DNER) & CAP 20 \\
\hline SMA-AC & $\begin{array}{c}\text { SMA DMN }=12 \mathrm{~mm} \\
\text { (AASHTO) }\end{array}$ & CAP 20 \\
\hline SMA-AP & $\begin{array}{c}\text { SMA DMN }=12 \mathrm{~mm} \\
\text { (AASHTO) }\end{array}$ & $\begin{array}{c}\text { Asfalto modificado } \\
\text { por polímero }\end{array}$ \\
\hline SMA-AB & $\begin{array}{c}\text { SMA DMN }=12 \mathrm{~mm} \\
\text { (AASHTO) }\end{array}$ & Asfalto-borracha \\
\hline
\end{tabular}




\subsection{Materiais}

Para a produção de amostras para a análise laboratorial foram utilizados agregados britados, ligantes asfálticos e fibras de celulose (de uso particular nas misturas SMA).

\subsubsection{Agregados}

Os agregados utilizados são provenientes da pedreira Bandeirantes, localizada próxima à cidade de São Carlos. Trata-se de um agregado basáltico britado, cujo fíler é proveniente do peneiramento do pó de pedra. Essa fonte de agregado foi escolhida por ter sido utilizada em diversas pesquisas do Departamento de Transportes da Escola de Engenharia de São Carlos da USP (STT-EESC-USP) e em muitas obras rodoviárias da região de São Carlos-SP.

O material foi submetido ao ensaio de Desgaste por Abrasão Los Angeles (DNER ME-035/64), tendo como resultado $28 \%$ de perda. Foi realizado também o ensaio de Massa Específica dos Sólidos, obtendo-se o resultado de $2,872 \mathrm{~g} / \mathrm{cm}^{3}$, válido para todas as frações de agregado (graúdo, fino e fíler).

O material disponível foi peneirado nas peneiras de abertura de $19,1 \mathrm{~mm}(3 / 4$ "), 12,7 mm (1/2"), 9,52 mm (3/8”), 4,76 mm (\# 4), 2,00 mm (\# 10), 0,42 mm (\# 40), $0,177 \mathrm{~mm}$ (\# 80) e $0,074 \mathrm{~mm}$ (\# 200). Todo o material retido na peneira de 2,00 $\mathrm{mm}$ foi lavado.

Os materiais separados nos intervalos dessas peneiras foram combinados para a obtenção da quantidade necessária para os corpos de prova e para as placas (ensaio de deformação permanente no simulador de tráfego LCPC). Foram escolhidas duas curvas granulométricas:

- Centro da Faixa C do DNER: utilizado para a mistura de referência (CBUQAC) devido ao grande uso dessa graduação em misturas asfálticas densas;

- Centro da faixa de SMA (especificação AASHTO MP-8), com diâmetro máximo nominal de $12,5 \mathrm{~mm}$ : graduação utilizada para concreto asfáltico destinado a camadas de rolamento com espessura entre 4 e 8 centímetros. 
A distribuição granulométrica da Faixa C (DNER) e das misturas SMA (AASHTO) são apresentadas na Tabela 3.2 e nas Figuras 3.1 e 3.2, e expressas em porcentagem passando em peso. A quantidade necessária de agregados em cada intervalo de peneiras para compor os corpos de prova é apresentada na Tabela 3.3. No caso das placas, a quantidade varia de acordo com a densidade aparente da mistura e, portanto, cada mistura tem sua composição (Tabelas 3.4 e 3.5).

Tabela 3.2 - Graduações da Faixa C (DNER) e SMA (AASHTO).

\begin{tabular}{|c|c|c|c|c|c|c|c|}
\hline \multirow{2}{*}{ Peneira } & \multirow{2}{*}{$\begin{array}{c}\text { Diâmetro } \\
\text { de abertura }\end{array}$} & \multicolumn{6}{|c|}{ Porcentagem passando em peso } \\
\cline { 3 - 8 } & (mm) & \multicolumn{3}{|c|}{ Faixa C (DNER) } & \multicolumn{3}{|c|}{ SMA (AASHTO) } \\
\cline { 3 - 8 } & & min & max & média & min & max & média \\
\hline $1 "$ & 25,4 & 100 & 100 & 100 & 100 & 100 & 100 \\
\hline $3 / 4 "$ & 19,1 & 100 & 100 & 100 & 100 & 100 & 100 \\
\hline $1 / 2 "$ & 12,7 & 85 & 100 & 92,5 & 90 & 100 & 95 \\
\hline $3 / 8 "$ & 9,52 & 75 & 100 & 87,5 & 26 & 78 & 52 \\
\hline$\# 4$ & 4,76 & 50 & 85 & 67,5 & 20 & 28 & 24 \\
\hline$\# 10$ & 2,00 & 30 & 75 & 52,5 & 15 & 23 & 19 \\
\hline$\# 40$ & 0,42 & 15 & 40 & 27,5 & 12 & 16 & 14 \\
\hline$\# 80$ & 0,177 & 8 & 30 & 19 & 11 & 13 & 12 \\
\hline$\# 200$ & 0,074 & 5 & 10 & 7,5 & 8 & 10 & 9 \\
\hline
\end{tabular}

Tabela 3.3 - Quantidade de agregado para compor um corpo de prova.

\begin{tabular}{|c|c|c|c|c|}
\hline \multirow{2}{*}{$\begin{array}{c}\text { Intervalo entre } \\
\text { peneiras }(\mathbf{m m})\end{array}$} & \multicolumn{2}{|c|}{ Faixa C } & \multicolumn{2}{c|}{ SMA } \\
\cline { 2 - 5 } & $\%$ & $\mathbf{( k g})$ & $\%$ & $\mathbf{( k g )}$ \\
\hline $19,1-12,7$ & 7,5 & 0,090 & 5 & 0,060 \\
\hline $12,7-9,52$ & 5 & 0,060 & 43 & 0,516 \\
\hline $9,52-4,76$ & 20 & 0,240 & 28 & 0,336 \\
\hline $4,76-2,00$ & 15 & 0,180 & 5 & 0,060 \\
\hline $2,00-0,42$ & 25 & 0,300 & 5 & 0,060 \\
\hline $0,42-0,177$ & 8,5 & 0,102 & 2 & 0,024 \\
\hline $0,177-0,074$ & 11,5 & 0,138 & 3 & 0,036 \\
\hline $0,074-$ fundo & 7,5 & 0,090 & 9 & 0,108 \\
\hline Total & 100 & 1,200 & 100 & 1,200 \\
\hline
\end{tabular}




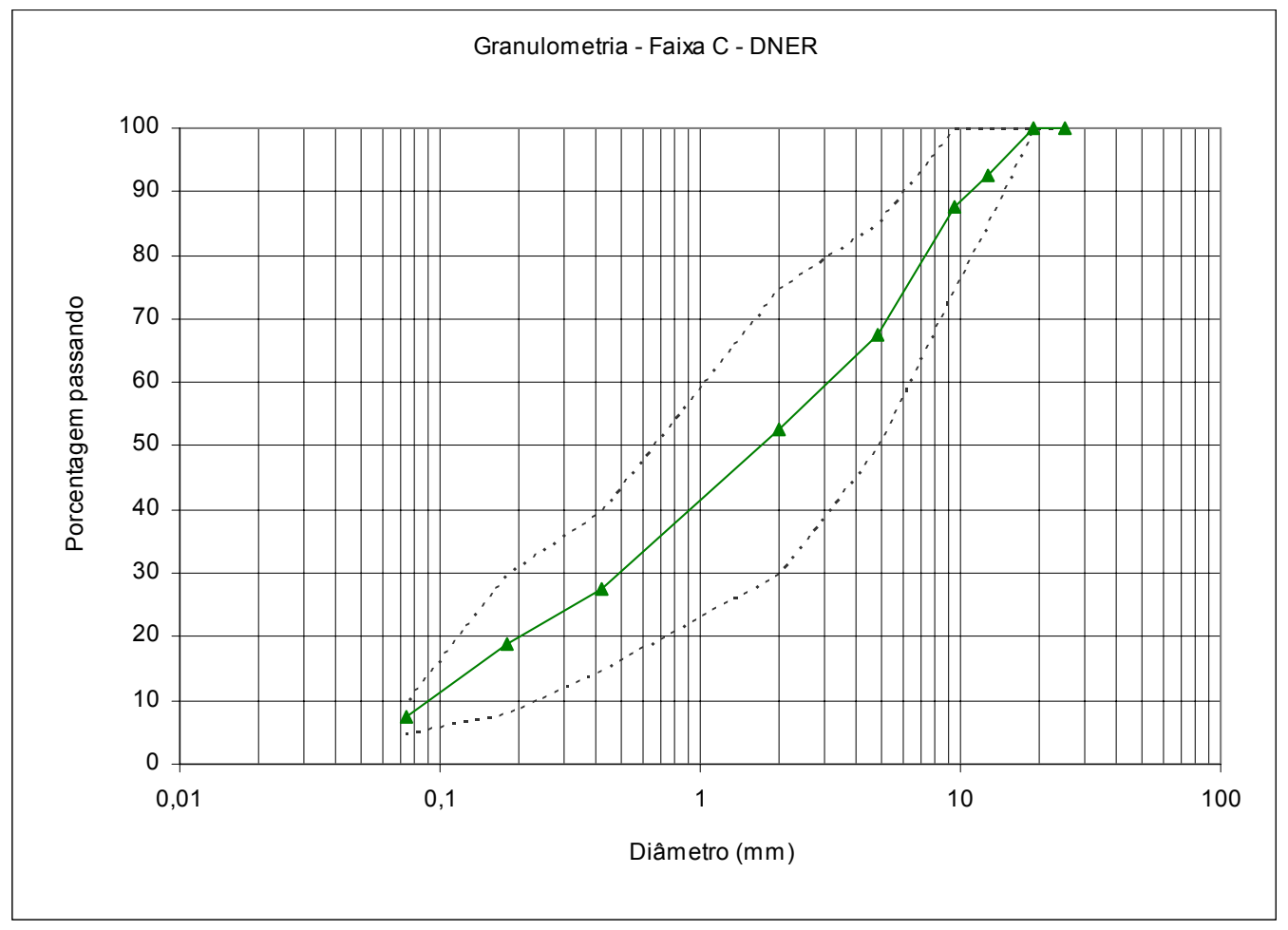

Figura 3.1 - Curva granulométrica da Faixa C (DNER).

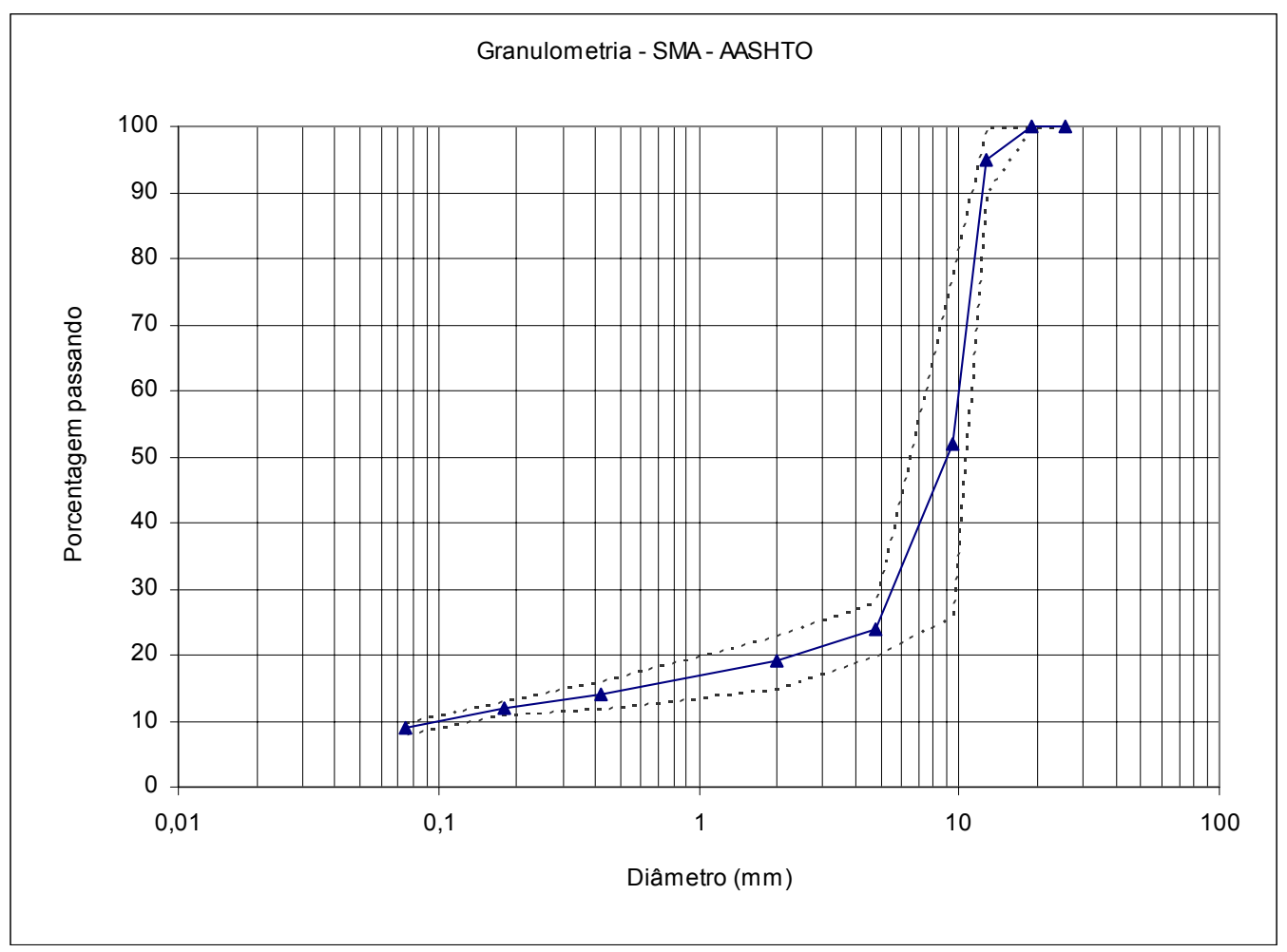

Figura 3.2 - Curva granulométrica do SMA (DMN = 12,5 mm, AASHTO). 
Tabela 3.4 - Quantidade de agregado para compor uma placa de CBUQ-AC.

\begin{tabular}{|c|c|c|}
\hline \multirow{2}{*}{$\begin{array}{c}\text { Intervalo entre } \\
\text { peneiras (mm) }\end{array}$} & \multicolumn{2}{|c|}{ CBUQ-AC } \\
\cline { 2 - 3 } & $\%$ & $(\mathrm{~kg})$ \\
\hline $19,1-12,7$ & 7,5 & 0,802 \\
\hline $12,7-9,52$ & 5 & 0,535 \\
\hline $9,52-4,76$ & 20 & 2,139 \\
\hline $4,76-2,00$ & 15 & 1,604 \\
\hline $2,00-0,42$ & 25 & 2,674 \\
\hline $0,42-0,177$ & 8,5 & 0,909 \\
\hline $0,177-0,074$ & 11,5 & 1,230 \\
\hline $0,074-$ fundo & 7,5 & 0,802 \\
\hline Total & 100 & 10,696 \\
\hline
\end{tabular}

Tabela 3.5 - Quantidade de agregado para compor uma placa de SMA.

\begin{tabular}{|c|c|c|c|c|}
\hline $\begin{array}{c}\text { Intervalo entre } \\
\text { peneiras }(\mathbf{m m})\end{array}$ & $\%$ & $\begin{array}{c}\text { SMA-AC } \\
\mathbf{( k g})\end{array}$ & $\begin{array}{c}\text { SMA-AP } \\
\mathbf{( k g )}\end{array}$ & $\begin{array}{c}\text { SMA-AB } \\
\mathbf{( k g )}\end{array}$ \\
\hline $19,1-12,7$ & 5 & 0,514 & 0,516 & 0,512 \\
\hline $12,7-9,52$ & 43 & 4,423 & 4,440 & 4,404 \\
\hline $9,52-4,76$ & 28 & 2,880 & 2,891 & 2,868 \\
\hline $4,76-2,00$ & 5 & 0,514 & 0,516 & 0,512 \\
\hline $2,00-0,42$ & 5 & 0,514 & 0,516 & 0,512 \\
\hline $0,42-0,177$ & 2 & 0,206 & 0,207 & 0,205 \\
\hline $0,177-0,074$ & 3 & 0,309 & 0,310 & 0,307 \\
\hline $0,074-$ fundo & 9 & 0,926 & 0,929 & 0,922 \\
\hline Total & 100 & 10,285 & 10,326 & 10,242 \\
\hline
\end{tabular}

\subsubsection{Ligante asfáltico}

Foram utilizados um cimento asfáltico convencional (CAP 20) e um asfalto modificado por polímero $(5 \%$ a $6 \%$ de polímero SBS, nome comercial Betuflex B 80/60), além do asfalto-borracha, objeto de avaliação deste trabalho. Para evitar a introdução de fatores não-controlados, procurou-se trabalhar com ligantes de uma mesma fonte. Portanto, para a produção do asfalto-borracha, não utilizado por REIS 
(2002), foi utilizado o mesmo cimento asfáltico. Todos os ligantes foram fornecidos pela Ipiranga Asfaltos S. A., bem como suas caracterizações, apresentadas nas Tabelas 3.6, 3.7 e 3.8 .

O ligante asfalto-borracha foi produzido com um teor de 18\% de borracha moída (passada na peneira \#80), misturada com o cimento asfáltico a uma temperatura acima de $200^{\circ} \mathrm{C}$, durante 1 hora, aproximadamente.

Tabela 3.6 - Caracterização do CAP 20 (Cimento Asfáltico de Petróleo).

\begin{tabular}{|c|c|c|c|c|}
\hline Ensaio & Método & Unid. & Especificação & Resultado \\
\hline Viscosidade Absoluta a $60^{\circ} \mathrm{C}$ & NBR 5847 & $\mathrm{p}$ & 2000 a 3500 & 2080 \\
\hline Viscosidade Saybolt Furol a $135^{\circ} \mathrm{C}$ & ASTM D 2161 & $\mathrm{~s}$ & $120 \mathrm{~min}$. & 183,7 \\
\hline Viscosidade Saybolt Furol a $177^{\circ} \mathrm{C}$ & ASTM D 2161 & $\mathrm{~s}$ & 30 a 150 & 31,9 \\
\hline Penetração & NBR 6576 & $0,1 \mathrm{~mm}$ & $50 \mathrm{~min}$. & 55 \\
\hline Ponto de fulgor & NBR 11341 & ${ }^{\circ} \mathrm{C}$ & $235 \mathrm{~min}$. & 328 \\
\hline Solubilidade no tricloroetileno & ASTM D 2042 & $\%$ & $99,5 \mathrm{~min}$ & 100,0 \\
\hline Densidade relativa a $20 / 4^{\circ} \mathrm{C}$ & ASTM D 70 & - & - & 1,006 \\
\hline Aquecimento a $175^{\circ} \mathrm{C}$ & - & - & - & Não espuma \\
\hline Índice de suscetibilidade térmica & - & - & $-1,5$ a 1,0 & $-1,4$ \\
\hline \multicolumn{5}{|l|}{ Efeito do calor e do ar a $163^{\circ} \mathrm{C}, 5 \mathrm{~h}$ : } \\
\hline Variação em massa & ASTM D 1754 & $\%$ & $1,0 \max$ & 0,06 \\
\hline Relação de viscosidade & - & - & 4,0 max & 1,5 \\
\hline Ductilidade a $25^{\circ} \mathrm{C}$ & NBR 6293 & $\mathrm{~cm}$ & $20 \mathrm{~min}$. & $>140$ \\
\hline
\end{tabular}


Tabela 3.7 - Caracterização do asfalto com polímero SBS (Betuflex B 80/60).

\begin{tabular}{|l|c|c|c|c|}
\hline \multicolumn{1}{|c|}{ Ensaio } & Método & Unid. & Especificação & Resultado \\
\hline Ponto de amolecimento & NBR 6560 & ${ }^{\circ} \mathrm{C}$ & $75-90$ & 81 \\
\hline Penetração $\left(100 \mathrm{~g}, 5 \mathrm{~s}, 25^{\circ} \mathrm{C}\right)$ & NBR 6576 & $0,1 \mathrm{~mm}$ & $50-70$ & 53 \\
\hline Viscosidade a $135^{\circ} \mathrm{C}$ & ASTM D 4402 & $\mathrm{cP}$ & 3000 máx. & 1240 \\
\hline Viscosidade a $145^{\circ} \mathrm{C}$ & ASTM D 4402 & $\mathrm{cP}$ & 2000 máx. & 870 \\
\hline Viscosidade a $175^{\circ} \mathrm{C}$ & ASTM D 4402 & $\mathrm{cP}$ & 450 máx. & 315 \\
\hline Ductilidade a $25^{\circ} \mathrm{C}$ & NBR 6293 & $\mathrm{~cm}$ & 100 min. & $>100$ \\
\hline Recuperação Elástica a $25^{\circ} \mathrm{C}$ & DNER ME $382 / 99$ & $\%$ & 85 min. & 96 \\
\hline Ponto de Fulgor & NBR 11341 & ${ }^{\circ} \mathrm{C}$ & 235 min. & $>300$ \\
\hline Densidade Relativa a $20 / 4^{\circ} \mathrm{C}$ & DNER ME $193 / 96$ & - & $1,00-1,04$ & 1,03 \\
\hline Estabilidade a $163^{\circ} \mathrm{C}, 5$ dias, $\Delta$ Pa & DNER ME $384 / 99$ & ${ }^{\circ} \mathrm{C}$ & 4,0 máx. & 0,9 \\
\hline Efeito do calor e do ar a $163^{\circ} \mathrm{C}, 5$ h: & NBR 14736 & $\%$ & 1,0 max. & 0,07 \\
\hline Variação em Massa & NBR 14736 & $\%$ & $>60$ & $>60$ \\
\hline$\%$ Penetração Original & DNER ME $382 / 99$ & $\%$ & 80 mín & 91 \\
\hline Recuperação Elástica a $25^{\circ} \mathrm{C}$
\end{tabular}

Tabela 3.8 - Caracterização do asfalto-borracha.

\begin{tabular}{|l|c|c|c|c|}
\hline \multicolumn{1}{|c|}{ Ensaio } & Método & Unid. & Especificação & Resultado \\
\hline Ponto de amolecimento & NBR 6560 & ${ }^{\circ} \mathrm{C}$ & $54,4 \mathrm{mín}$ & 55 \\
\hline Penetração $\left(100 \mathrm{~g}, 5 \mathrm{~s}, 25^{\circ} \mathrm{C}\right)$ & NBR 6576 & $0,1 \mathrm{~mm}$ & $25-75$ & 38 \\
\hline Ductilidade a $25^{\circ} \mathrm{C}$ & NBR 6293 & $\mathrm{~cm}$ & 5 mín & 37,8 \\
\hline Viscosidade a $135^{\circ} \mathrm{C}$ & ASTM D 4402 & $\mathrm{cP}$ & & 1882 \\
\hline Viscosidade a $145^{\circ} \mathrm{C}$ & ASTM D 4402 & $\mathrm{cP}$ & & 853 \\
\hline Viscosidade a $175^{\circ} \mathrm{C}$ & ASTM D 4402 & $\mathrm{cP}$ & & 281,5 \\
\hline Recuperação Elástica a $25^{\circ} \mathrm{C}$ & DNER ME $382 / 99$ & $\%$ & 20 mín & 26,7 \\
\hline Ponto de Fulgor & NBR 11341 & ${ }^{\circ} \mathrm{C}$ & 232,2 mín & $>240$ \\
\hline Densidade Relativa a $20 / 4{ }^{\circ} \mathrm{C}$ & DNER ME $193 / 96$ & & & 1,030 \\
\hline Efeito do calor e do ar a $163^{\circ} \mathrm{C}, 5 \mathrm{~h}:$ & \multicolumn{5}{|l|}{} & 0,0 \\
\hline Variação em Massa & NBR 14736 & $\%$ & & 33 \\
\hline Penetração $\left(100 \mathrm{~g}, 5 \mathrm{~s}, 25^{\circ} \mathrm{C}\right)$ & NBR 6576 & $0,1 \mathrm{~mm}$ & & 57,2 \\
\hline Ponto de amolecimento & NBR 6560 & ${ }^{\circ} \mathrm{C}$ & & 36,2 \\
\hline Ductilidade a $25^{\circ} \mathrm{C}$ & NBR 6293 & $\mathrm{cm}$ & & 1750 \\
\hline Viscosidade a $135^{\circ} \mathrm{C}$ & ASTM D 4402 & $\mathrm{cP}$ & & 1190 \\
\hline Viscosidade a $145^{\circ} \mathrm{C}$ & ASTM D 4402 & $\mathrm{cP}$ & & 350 \\
\hline Viscosidade a $175^{\circ} \mathrm{C}$ & ASTM D 4402 & $\mathrm{cP}$ & & 41,7 \\
\hline Recuperação Elástica a $25^{\circ} \mathrm{C}$ & DNER ME $382 / 99$ & $\%$ & & \\
\hline
\end{tabular}


A norma DNER ME-043/95 estabelece intervalos de temperatura para usinagem e compactação do concreto asfáltico para o ensaio Marshall. Esses intervalos correspondem a faixas de viscosidade do ligante utilizado na mistura. Para a usinagem, o ligante deve ser aquecido a uma temperatura na qual apresente uma viscosidade de $85 \pm 10$ sSF (segundos, ensaio Saybolt-Furol), enquanto que a temperatura para compactação da mistura é aquela em que o ligante apresenta uma viscosidade de $140 \pm 15 \mathrm{sSF}$.

O ensaio de viscosidade Saybolt-Furol não é adequado para ligantes que possuem viscosidade elevada. Nesses casos, realiza-se o ensaio de viscosidade aparente com o viscosímetro Brookfield (ASTM D 4402). Os ligantes asfalto-polímero e asfaltoborracha utilizados neste trabalho tiveram as suas viscosidades medidas dessa forma. As viscosidades de mistura e compactação do concreto asfáltico são de $200 \mathrm{cP}$ e $300 \mathrm{cP}$, respectivamente, para o ensaio de dosagem Marshall segundo a norma da ABNT NBR 12891.

A partir dos resultados de caracterização dos ligantes asfálticos CAP 20, asfalto com polímero e asfalto-borracha são apresentados os intervalos de temperatura para mistura e compactação do concreto asfáltico na Tabela 3.9.

Tabela 3.9 - Temperatura para mistura e compactação das misturas asfálticas.

\begin{tabular}{|c|c|c|c|}
\hline & CAP 20 & Asfalto com polímero & Asfalto-borracha \\
\hline Mistura & $151^{\circ} \mathrm{C} \mathrm{a} 156^{\circ} \mathrm{C}$ & $170^{\circ} \mathrm{C}$ a $174^{\circ} \mathrm{C}$ & $167^{\circ} \mathrm{C}$ a $171^{\circ} \mathrm{C}$ \\
\hline Compactação & $139^{\circ} \mathrm{C} \mathrm{a} 144^{\circ} \mathrm{C}$ & $165^{\circ} \mathrm{C}$ a $169^{\circ} \mathrm{C}$ & $164^{\circ} \mathrm{C}$ a $168^{\circ} \mathrm{C}$ \\
\hline
\end{tabular}

\subsubsection{Fibras}

Foram utilizadas fibras de celulose, nome comercial VIATOP 66, com teor em peso de $0,3 \%$ do total da mistura, doadas pela empresa Ecofibras. Trata-se de uma fibra de celulose envolta em asfalto e na forma peletizada (grãos). O numero 66 indica que contém $66 \%$ de fibra e $34 \%$ de asfalto. 


\subsection{Projeto das Misturas Asfálticas}

Para a produção das misturas asfálticas utilizadas nos ensaios de laboratório deve-se verificar a distribuição granulométrica e selecionar o teor de ligante. O projeto das misturas produzidas com a graduação da Faixa C segue as normas do DNER, enquanto que para as misturas SMA são utilizados o procedimento AASHTO PP-41 e a especificação AASHTO MP-8.

\subsubsection{Verificação da granulometria}

No caso da mistura de referência (CBUQ-AC), como a curva granulométrica utilizada corresponde ao centro da Faixa $\mathrm{C}$, as exigências do DNER quanto à granulometria já são atendidas. Contudo, com relação ao SMA, antes de se fazer a dosagem do teor de ligante, há a necessidade de se verificar o contato pedra-pedra da graduação escolhida. No caso deste trabalho, foi escolhida a curva situada no centro da faixa com diâmetro máximo nominal de $12,5 \mathrm{~mm}$.

Esta verificação é feita através de um método desenvolvido pelo NCAT (AASHTO PP-41), que faz as seguintes exigências: o valor dos vazios do agregado graúdo da mistura em estado seco compactado $\left(\mathrm{VAG}_{\mathrm{sc}}\right)$ deve ser maior que o valor dos vazios do agregado graúdo da mistura compactada com ligante asfáltico $\left(\mathrm{VAG}_{\mathrm{mc}}\right)$ e o valor mínimo para os vazios do agregado mineral (VAM) deve ser de 17\%.

O cálculo do $\mathrm{VAG}_{\mathrm{sc}}$ e do $\mathrm{VAG}_{\mathrm{mc}}$ é feito segundo as Equações 3.1 e 3.2:

$\mathrm{VAG}_{\mathrm{sc}}=\frac{\gamma_{a g}-\gamma_{s c}}{\gamma_{a g}} \cdot 100 \quad$ (3.1) e $\quad \mathrm{VAG}_{\mathrm{mc}}=100-\frac{D_{a p}}{\gamma_{a g}} \cdot P_{a g}$

onde:

$\gamma_{\mathrm{ag}}=$ massa específica do agregado graúdo em $\mathrm{g} / \mathrm{cm}^{3}$;

$\gamma_{\mathrm{sc}}=$ massa específica aparente no estado compactado seco em $\mathrm{g} / \mathrm{cm}^{3}$;

$\mathrm{D}_{\mathrm{ap}}=$ densidade aparente da mistura;

$\mathrm{P}_{\mathrm{ag}}=$ porcentagem de agregado graúdo na mistura total, em peso. 
A fração considerada graúda para a graduação SMA $(\mathrm{DMN}=12,5 \mathrm{~mm})$ é retida na peneira de abertura de 4,76 $\mathrm{mm}$ (peneira N. ${ }^{\circ}$ 4), denominada de ponto de quebra. Para se obter $\gamma_{\mathrm{sc}}$ é preciso que se realize o ensaio da AASHTO T-19 (Unit Weight and Voids in Aggregate), que corresponde ao DNER-ME 153/97 (Agregado em estado compactado seco - determinação da massa específica aparente), conforme exige a norma americana para SMA (AASHTO PP-41). Esse ensaio foi realizado no Laboratório de Materiais Avançados à Base de Cimento (LMABC) do Departamento de Engenharia de Estruturas da EESC-USP.

Os vazios do agregado mineral (VAM) representam a soma do volume de vazios com o volume preenchido por betume, expresso em porcentagem. Esta propriedade não tem tanto destaque nas dosagens de misturas asfálticas pelo método Marshall, porém o método Superpave dá grande atenção a este parâmetro. Apesar de se exigir apenas um valor mínimo para o VAM, não se recomenda aumentá-lo demais para que a mistura não fique com pouca estabilidade e, conseqüentemente, com uma tendência ao acúmulo de deformação permanente nas trilhas de roda.

\subsubsection{Seleção do teor asfáltico de projeto}

O teor de ligante adotado nas misturas asfálticas foi obtido a partir do ensaio de dosagem Marshall, seguindo as instruções do método de ensaio DNER ME-043/95. Contudo, vale ressaltar que foi feito o envelhecimento de curto prazo, seguindo o procedimento AASHTO PP-2 (Standard Practice for Mixture Conditioning of Hot Mix Asphalt), que estabelece que, depois de usinada, a mistura asfáltica deve ficar por duas horas numa estufa à temperatura de compactação, antes de se fazer a moldagem do corpo de prova.

A compactação dos corpos de prova foi feita com 50 golpes por face para as misturas SMA, seguindo o procedimento AASHTO PP-41, e 75 golpes por face para a mistura de referência (CBUQ-AC), conforme o método DNER-ME 043/95 determina para rodovias de alto volume de tráfego. Com os corpos de prova compactados, foi determinada a densidade aparente da mistura seguindo o método de ensaio AASHTO T166. Com este dado, foram calculados o volume de vazios $\left(\mathrm{V}_{\mathrm{v}}\right)$, a relação betume/vazios (RBV), os vazios do agregado mineral (VAM) e o $\mathrm{VAG}_{\mathrm{mc}}$ (particularmente para as 
misturas SMA). Posteriormente, os corpos de prova foram rompidos e os valores de estabilidade (E) e fluência (F) determinados.

Na seqüência, foram traçados gráficos de $D_{a p}, E, F, V_{v}$ e RBV em função do teor asfáltico, visando atender aos limites estabelecidos pela especificação DNER ES313/97, apresentados na Tabela 3.10 .

Tabela 3.10 - Limites estabelecidos pela especificação DNER ES-313/97.

\begin{tabular}{|l|c|c|}
\hline \multicolumn{2}{|c|}{ Discriminação } & Limites \\
\hline \multicolumn{2}{|c|}{ Volume de Vazios (\%) } & 3 a 5 \\
\hline \multicolumn{2}{|c|}{ Relação betume/vazios (\%) } & 75 a 82 \\
\hline $\begin{array}{c}\text { Estabilidade } \\
\text { (kgf) }\end{array}$ & CAP convencional & min. 350 \\
\cline { 2 - 3 } CAP modificado & min. 500 \\
\hline Fluência (mm) & 2,0 a 4,5 \\
\hline
\end{tabular}

Durante o desenvolvimento da tecnologia das misturas SMA, o volume de vazios adotado para a dosagem de um concreto asfáltico foi muito discutido e ainda existem diferenças nos valores exigidos nos países pesquisados. Em 1991, quando do início das pesquisas sobre SMA na América do Norte, o Canadá e o Estado de Michigan adotaram $\mathrm{V}_{\mathrm{v}}=3 \%$. O manual de projeto do NCAT determina um valor de 4\%. A Tabela 3.11 traz o volume de vazios de projeto para alguns países da Europa.

Tabela 3.11 - Volume de vazios adotados para seleção do teor de projeto.

\begin{tabular}{|c|c|}
\hline País & Volume de vazios (\%) \\
\hline Alemanha & $3,0-4,0$ \\
\hline Dinamarca & $1,5-4,0$ \\
\hline Holanda & 5,0 \\
\hline Hungria & $3,0-4,5$ \\
\hline Itália & $1,0-4,0$ \\
\hline Noruega & $2,0-5,0$ \\
\hline Portugal & $3,0-5.0$ \\
\hline República Tcheca & $3,0-4,5$ \\
\hline Suécia & $2,7-4,9$ \\
\hline
\end{tabular}

Fonte: EAPA (1998) 
Neste trabalho, com os resultados da dosagem, foi definido como teor de ligante de projeto o correspondente a um volume de vazios em torno de $4 \%$.

\subsection{Avaliação das Propriedades Mecânicas}

A avaliação das misturas asfálticas SMA e a comparação com uma mistura de referência (CBUQ-AC) é feita a partir de resultados de ensaios de laboratório, que buscam verificar o comportamento de misturas asfálticas com relação aos principais mecanismos de deterioração: deformação permanente, trincas por fadiga e danos causados pela ação da água (desgaste).

\subsubsection{Resistência a danos causados por umidade induzida}

Para que uma mistura asfáltica não tenha problemas de descolamento da película de ligante e, conseqüentemente, desagregação, é necessário que haja uma boa adesividade entre o ligante e os agregados. Caso esta adesividade seja insatisfatória, pode-se fazer uso de aditivos aos ligantes (Dope) ou aos agregados (cal hidratada). Os métodos do DNER têm apresentado inconsistências ao avaliar esta propriedade. Por outro lado, o ensaio AASHTO T-283/99 (Resistance of Compacted Bituminous Mixture to Moisture Induced Damage), que avalia a adesividade através da indução severa de água para dentro de um corpo de prova de concreto asfáltico, tem sido apontado como um bom parâmetro de avaliação da adesividade entre ligante e agregado.

Para avaliar a adesividade dos agregados utilizados neste trabalho, o ensaio de resistência de misturas asfálticas compactadas a danos causados por umidade induzida foi realizado com uma mistura com graduação da Faixa C (DNER) e cimento asfáltico convencional (CAP 20), chamada neste trabalho de CBUQ-AC.

O ensaio (AASHTO T-283) consiste na moldagem de no mínimo 6 corpos de prova com teor asfáltico de projeto e volume de vazios entre $6 \%$ e $8 \%$. Portanto, a compactação deve ser feita com um número baixo de golpes por face. Na seqüência, é determinada a densidade aparente dos corpos de prova através do método AASHTO T166. Os corpos de prova são separados em dois grupos, de forma que a média do volume de vazios dos grupos seja bem próxima. 
Um grupo é submetido a um condicionamento que envolve uma saturação de água entre $55 \%$ e $80 \%$, um resfriamento a $-18{ }^{\circ} \mathrm{C}$ durante 16 horas, um aquecimento em banho-maria a $60^{\circ} \mathrm{C}$ durante 24 horas e um resfriamento ates banho a $25^{\circ} \mathrm{C}$ por 2 horas.

Depois do condicionamento, os corpos de prova são ensaiados para se determinar a resistência à tração indireta por compressão diametral, calcula-se a média aritmética de cada grupo e, posteriormente, a relação de resistência à tração (Equação 3.3). Quando a relação de resistência à tração é superior a $70 \%$ considera-se que a mistura asfáltica não apresenta problemas com a adesividade.

$$
R R T=\frac{R T_{1}}{R T_{2}}
$$

onde:

RRT $=$ relação de resistência à tração;

$\mathrm{RT}_{1}=$ média da resistência à tração do grupo submetido ao condicionamento;

$\mathrm{RT}_{2}=$ média da resistência à tração do grupo não submetido ao condicionamento.

\subsubsection{Resistência à tração e módulo de resiliência}

A resistência à tração das misturas asfálticas é obtida através do ensaio de compressão diametral aplicado a corpos de prova cilíndricos, seguindo o método DNER-ME 138/94. Neste trabalho, a mistura foi produzida com teor asfáltico de projeto e os corpos de prova moldados no compactador Marshall.

$\mathrm{O}$ ensaio, que neste trabalho foi realizado a uma temperatura de $25^{\circ} \mathrm{C}$, consiste em aplicar a carga progressivamente com uma velocidade de deformação de $0,8 \pm$ $0,1 \mathrm{~mm} / \mathrm{s}$, até a ruptura. Através da carga de ruptura e das dimensões do corpo de prova calcula-se a resistência à tração segundo a Equação 3.4:

$$
\sigma_{T}=\frac{2 \cdot F}{\pi \cdot D \cdot H \cdot 10,2}
$$


onde:

$\sigma_{\mathrm{T}}=$ resistência à tração em $\mathrm{MPa}$;

$\mathrm{F}=$ carga de ruptura em kgf;

$\mathrm{D}=$ diâmetro do corpo de prova em $\mathrm{cm}$;

$\mathrm{H}=$ altura do corpo de prova $\mathrm{em} \mathrm{cm}$.

Cada vez mais, o dimensionamento de pavimentos flexíveis é feito através de métodos mecanísticos, que requerem o módulo de resiliência da mistura asfáltica utilizada no revestimento do pavimento. O módulo de resiliência de uma mistura asfáltica é a relação entre a tensão aplicada a um corpo de prova e a deformação elástica (recuperável) correspondente.

Para se determinar o módulo de resiliência de misturas asfálticas existem diferentes métodos. Neste trabalho, foi realizado o ensaio de tração indireta com carga repetida, seguindo o método DNER-ME 133/94, onde foram utilizados corpos de prova moldados no compactador Marshall, com teor asfáltico de projeto, temperatura do ensaio de $25{ }^{\circ} \mathrm{C}$ e carga aplicada correspondente a, aproximadamente, uma tensão equivalente a $15 \%$ da resistência à tração da mistura asfáltica.

A carga é aplicada com uma freqüência de $1 \mathrm{~Hz}$ e duração de 0,1 segundo. As deformações resilientes são medidas por um transdutor mecânico-eletromagnético tipo LVDT (Linear Variable Differential Transformer), que envia as informações a um programa computacional de aquisição de dados. O módulo de resiliência é calculado pela equação 3.5 :

$$
M_{R}=\frac{F}{10,2 \cdot \Delta \cdot H} \cdot(0,9976 \cdot \mu+0,2692)
$$

onde:

$\mathrm{M}_{\mathrm{R}}=$ módulo de resiliência em $\mathrm{MPa}$;

$\mathrm{F}=$ carga vertical repetida aplicada diametralmente ao corpo de prova em $\mathrm{kgf}$;

$\Delta=$ deslocamento elástico ou resiliente em cm;

$\mathrm{H}=$ altura do corpo de prova em $\mathrm{cm}$;

$\mu=$ coeficiente de Poisson. 
Os ensaios de resistência à tração e módulo de resiliência foram realizados no Laboratório de Tecnologia de Pavimentação da Escola Politécnica da USP (LTPEPUSP).

\subsubsection{Deformação permanente em trilha de roda}

Como já foi enfatizado anteriormente, uma grande preocupação ao se projetar um revestimento asfáltico consiste na deformação permanente. Portanto, neste trabalho a resistência à deformação permanente nas trilhas de roda será avaliada através do equipamento simulador de tráfego LCPC (Laboratoire Central de Ponts e Chaussées), do LTP-EPUSP.

São moldadas placas de concreto asfáltico produzidas com teor asfáltico de projeto, mediante amassamento em uma mesa compactadora tipo LCPC. As placas têm $18,0 \mathrm{~cm}$ de largura, 50,0 cm de comprimento, 5,0 cm de altura e pesam entre $11 \mathrm{e} 12 \mathrm{~kg}$, dependendo da densidade aparente da mistura asfáltica.

O ensaio é realizado a uma temperatura de $60^{\circ} \mathrm{C}$ e faz-se leituras do afundamento em 15 pontos da superfície da placa após 100, 300, 1000, 3000, 10000 e 30000 ciclos. A deformação permanente é a razão entre a média aritmética dos afundamentos, em milímetros, e a espessura inicial da placa, também em milímetros. Traça-se, então, um gráfico log-log da deformação permanente em função do número de ciclos. A norma francesa NF P 98-253-1 fixa em 5\% o limite máximo de deformação permanente, após 30000 ciclos, para revestimento de pavimentos submetidos a tráfego muito pesado, e $10 \%$ para tráfego leve.

\subsubsection{Ensaio de Fadiga}

Considerando-se a importância da avaliação da resistência ao aparecimento e propagação de trincas por fadiga de uma mistura asfáltica, destacada no Capítulo 2 deste trabalho, foi realizado o ensaio de fadiga utilizando-se corpos de prova cilíndricos submetidos a compressão diametral com carga repetida, seguindo o mesmo procedimento do ensaio de módulo de resiliência, porém com aplicação de diferentes cargas verticais, correspondentes a tensões de tração que variam entre $10 \%$ e $50 \%$ da resistência à tração da mistura asfáltica. 
Os corpos de prova foram moldados no compactador Marshall, com teor asfáltico de projeto. $\mathrm{O}$ ensaio foi realizado a uma temperatura de $25^{\circ} \mathrm{C}$ e a carga foi aplicada até que ocorresse a ruptura do corpo de prova, ou quando o deslocamento fosse superior a $3,5 \mathrm{~mm}$. A curva de fadiga de cada mistura asfáltica é obtida em um gráfico do número de repetições em função da diferença de tensões $(\Delta \sigma)$ de tração e de compressão no centro do corpo de prova, que permite a comparação das misturas com relação à resistência ao aparecimento e propagação de trincas por fadiga. $\mathrm{O}$ ensaio de fadiga foi realizado no LTP-EPUSP.

$$
\begin{aligned}
\Delta \sigma & =\sigma_{T}-\sigma_{C} \\
\sigma_{T} & =\frac{2 \cdot F}{\pi \cdot D \cdot H \cdot 10,2} \\
\sigma_{C} & =-\frac{6 \cdot F}{\pi \cdot D \cdot H \cdot 10,2}
\end{aligned}
$$

onde:

$\Delta \sigma=$ diferença de tensões em MPa;

$\sigma_{\mathrm{T}}=$ tensão de tração em MPa;

$\sigma_{\mathrm{C}}=$ tensão de compressão em MPa;

$\mathrm{F}=$ carga de ruptura em $\mathrm{kgf}$;

$\mathrm{D}=$ diâmetro do corpo de prova em $\mathrm{cm}$;

$\mathrm{H}=$ altura do corpo de prova em $\mathrm{cm}$. 


\section{ANÁLISE DOS RESULTADOS}

\subsection{Projeto da Mistura Asfáltica}

\subsubsection{Verificação da granulometria}

A massa específica aparente em estado seco compactado $\left(\gamma_{\mathrm{sc}}\right)$ foi determinada através do ensaio DNER-ME 153/97, realizado no Laboratório de Materiais Avançados à Base de Cimento do Departamento de Engenharia de Estruturas da EESC-USP (LMABC-EESC-USP). Juntamente com os valores da massa específica do agregado graúdo e da massa específica da água, possibilitou o cálculo dos vazios do agregado graúdo da mistura em estado seco compactado $\left(\mathrm{VAG}_{\mathrm{sc}}\right)$, utilizando a Equação 3.1.

Tabela 4.1 - Cálculo de $\mathrm{VAG}_{\mathrm{sc}}$.

\begin{tabular}{|l|l|}
\hline Massa específica do agregado graúdo $\left(\gamma_{\mathrm{ag}}\right)$ & $2,872 \mathrm{~g} / \mathrm{cm}^{3}$ \\
\hline Massa específica aparente em estado compactado seco $\left(\gamma_{\mathrm{sc}}\right)$ & $1,608 \mathrm{~g} / \mathrm{cm}^{3}$ \\
\hline Vazios do agregado graúdo em estado seco compactado $\left(\mathrm{VAG}_{\mathrm{sc}}\right)$ & $44,0 \%$ \\
\hline
\end{tabular}

A partir dos resultados das dosagens Marshall das misturas SMA com dois tipos de ligante (asfalto com polímero e asfalto-borracha), foram calculados os valores de vazios do agregado graúdo da mistura compactada com ligante asfáltico $\left(\mathrm{VAG}_{\mathrm{mc}}\right)$ e de vazios do agregado mineral (VAM).

Como se pode observar na Tabela 4.2, nas duas misturas produzidas o $\mathrm{VAG}_{\mathrm{mc}}$ é menor que o $\mathrm{VAG}_{\mathrm{sc}}$, em todos os teores asfálticos. O mesmo acontece para o VAM, que em todas as misturas e para todos os teores está acima de $17 \%$. Portanto, as exigências 
para a distribuição granulométrica de misturas asfálticas SMA da especificação AASHTO MP-8 foram atendidas.

Tabela 4.2 - Cálculo de vazios do agregado graúdo da mistura compactada com ligante asfáltico $\left(\mathrm{VAG}_{\mathrm{mc}}\right)$.

\begin{tabular}{|c|c|c|c|c|c|}
\hline Misturas & $\begin{array}{c}\text { Porcentagem } \\
\text { de ligante }\end{array}$ & $\begin{array}{c}\text { Porcentagem de } \\
\text { agregado graúdo }\end{array}$ & $\begin{array}{c}\text { Densidade } \\
\text { Aparente }\end{array}$ & $\begin{array}{c}\mathbf{V A G}_{\mathbf{m c}} \\
\mathbf{( \% )}\end{array}$ & $\begin{array}{c}\text { VAM } \\
\mathbf{( \% )}\end{array}$ \\
\hline \multirow{3}{*}{ SMA-AP } & 5,2 & 71,8 & 2,454 & 38,62 & 19,23 \\
\cline { 2 - 6 } & 5,7 & 71,5 & 2,459 & 38,82 & 19,50 \\
\cline { 2 - 6 } & 6,2 & 71,1 & 2,451 & 39,35 & 20,19 \\
\hline \multirow{3}{*}{ SMA-AB } & 6,7 & 70,7 & 2,457 & 39,71 & 20,67 \\
\cline { 2 - 6 } & 5,5 & 71,6 & 2,440 & 39,17 & 19,96 \\
\cline { 2 - 6 } & 6,0 & 71,2 & 2,432 & 39,69 & 20,65 \\
\cline { 2 - 6 } & 6,5 & 70,8 & 2,442 & 39,77 & 20,75 \\
\hline
\end{tabular}

\subsubsection{Seleção do teor asfáltico de projeto}

O teor asfáltico de projeto foi selecionado a partir dos resultados da dosagem Marshall para as misturas de CBUQ convencional (mistura de referência) e de SMA. Conforme previsto, a dosagem do CBUQ convencional foi realizada com uma mistura asfáltica de graduação no centro da Faixa C (DNER) e cimento asfáltico convencional (CAP 20). Os resultados são apresentados na Tabela 4.3 e nos gráficos da Figura 4.1.

No caso das misturas SMA, primeiramente foi feita uma dosagem Marshall com CAP 20, porém os resultados não foram satisfatórios. Isto ocorreu devido à falta de experiência em dosagens Marshall com esse tipo de mistura no Laboratório de Estradas do STT-EESC-USP. Então, o processo de usinagem e compactação dos corpos de prova foi revisto e foram realizadas novas dosagens Marshall para SMA com asfalto modificado por polímero e com asfalto-borracha (Tabelas 4.4 e 4.5 e Figuras 4.2 e 4.3).

Os resultados da dosagem Marshall ficaram dentro do esperado. Para a mistura de referência, com graduação no centro da Faixa C (DNER), cimento asfáltico convencional e para um volume de vazios de 4\%, o teor asfáltico correspondente foi de 5,3\%, valor adotado por atender todas as exigências da especificação DNER-ES 313/97. 
Tabela 4.3 - Resultados da dosagem Marshall - CBUQ-AC.

\begin{tabular}{|c|c|c|c|c|c|c|c|}
\hline $\begin{array}{c}\text { Porcent. } \\
\text { ligante }\end{array}$ & $\begin{array}{c}\text { Porcent. } \\
\text { agregado }\end{array}$ & $\begin{array}{c}\text { Densidade } \\
\text { Aparente }\end{array}$ & $\begin{array}{c}\text { Densidade } \\
\text { Teórica }\end{array}$ & $\begin{array}{c}\text { Vv } \\
\mathbf{( \% )}\end{array}$ & $\begin{array}{c}\text { RBV } \\
\mathbf{( \% )}\end{array}$ & $\begin{array}{c}\text { Estabilidade } \\
\mathbf{( k g f})\end{array}$ & $\begin{array}{c}\text { Fluência } \\
(\mathbf{m m})\end{array}$ \\
\hline 4,5 & 95,5 & 2,471 & 2,651 & 6,77 & 62,0 & 1415 & 2,96 \\
\hline 5,0 & 95,0 & 2,502 & 2,628 & 4,82 & 72,2 & 1622 & 3,47 \\
\hline 5,5 & 94,5 & 2,520 & 2,606 & 3,31 & 80,6 & 1874 & 3,73 \\
\hline 6,0 & 94,0 & 2,526 & 2,584 & 2,25 & 87,0 & 1631 & 4,49 \\
\hline 6,5 & 93,5 & 2,516 & 2,563 & 1,85 & 89,8 & 1351 & 5,08 \\
\hline
\end{tabular}

Tabela 4.4 - Resultados da dosagem Marshall - SMA-AP.

\begin{tabular}{|c|c|c|c|c|c|c|c|}
\hline $\begin{array}{c}\text { Porcent. } \\
\text { ligante }\end{array}$ & $\begin{array}{c}\text { Porcent. } \\
\text { agregado }\end{array}$ & $\begin{array}{c}\text { Densidade } \\
\text { Aparente }\end{array}$ & $\begin{array}{c}\text { Densidade } \\
\text { Teórica }\end{array}$ & $\begin{array}{c}\text { Vv } \\
\mathbf{( \% )}\end{array}$ & $\begin{array}{c}\text { RBV } \\
(\mathbf{\%})\end{array}$ & $\begin{array}{c}\text { Estabilidade } \\
\text { (kgf) }\end{array}$ & $\begin{array}{c}\text { Fluência } \\
\text { (mm) }\end{array}$ \\
\hline 5,2 & 94,5 & 2,454 & 2,619 & 6,29 & 66,3 & 1006 & 2,46 \\
\hline 5,7 & 94,0 & 2,459 & 2,598 & 5,34 & 71,8 & 1008 & 2,88 \\
\hline 6,2 & 93,5 & 2,451 & 2,577 & 4,90 & 75,1 & 945 & 2,96 \\
\hline 6,7 & 93,0 & 2,457 & 2,557 & 3,90 & 80,4 & 1061 & 3,30 \\
\hline
\end{tabular}

Tabela 4.5 - Resultados da dosagem Marshall - SMA-AB.

\begin{tabular}{|c|c|c|c|c|c|c|c|}
\hline $\begin{array}{c}\text { Porcent. } \\
\text { ligante }\end{array}$ & $\begin{array}{c}\text { Porcent. } \\
\text { agregado }\end{array}$ & $\begin{array}{c}\text { Densidade } \\
\text { Aparente }\end{array}$ & $\begin{array}{c}\text { Densidade } \\
\text { Teórica }\end{array}$ & $\begin{array}{c}\text { Vv } \\
\mathbf{( \% )}\end{array}$ & $\begin{array}{c}\text { RBV } \\
\mathbf{( \% )}\end{array}$ & $\begin{array}{c}\text { Estabilidade } \\
\text { (kgf) }\end{array}$ & $\begin{array}{c}\text { Fluência } \\
\text { (mm) }\end{array}$ \\
\hline 5,5 & 94,2 & 2,440 & 2,595 & 5,99 & 69,2 & 801 & 0,88 \\
\hline 6,0 & 93,7 & 2,432 & 2,573 & 5,50 & 72,6 & 722 & 1,12 \\
\hline 6,5 & 93,2 & 2,442 & 2,552 & 4,32 & 78,6 & 736 & 1,10 \\
\hline 7,0 & 92,7 & 2,440 & 2,531 & 3,58 & 82,7 & 667 & 1,23 \\
\hline
\end{tabular}




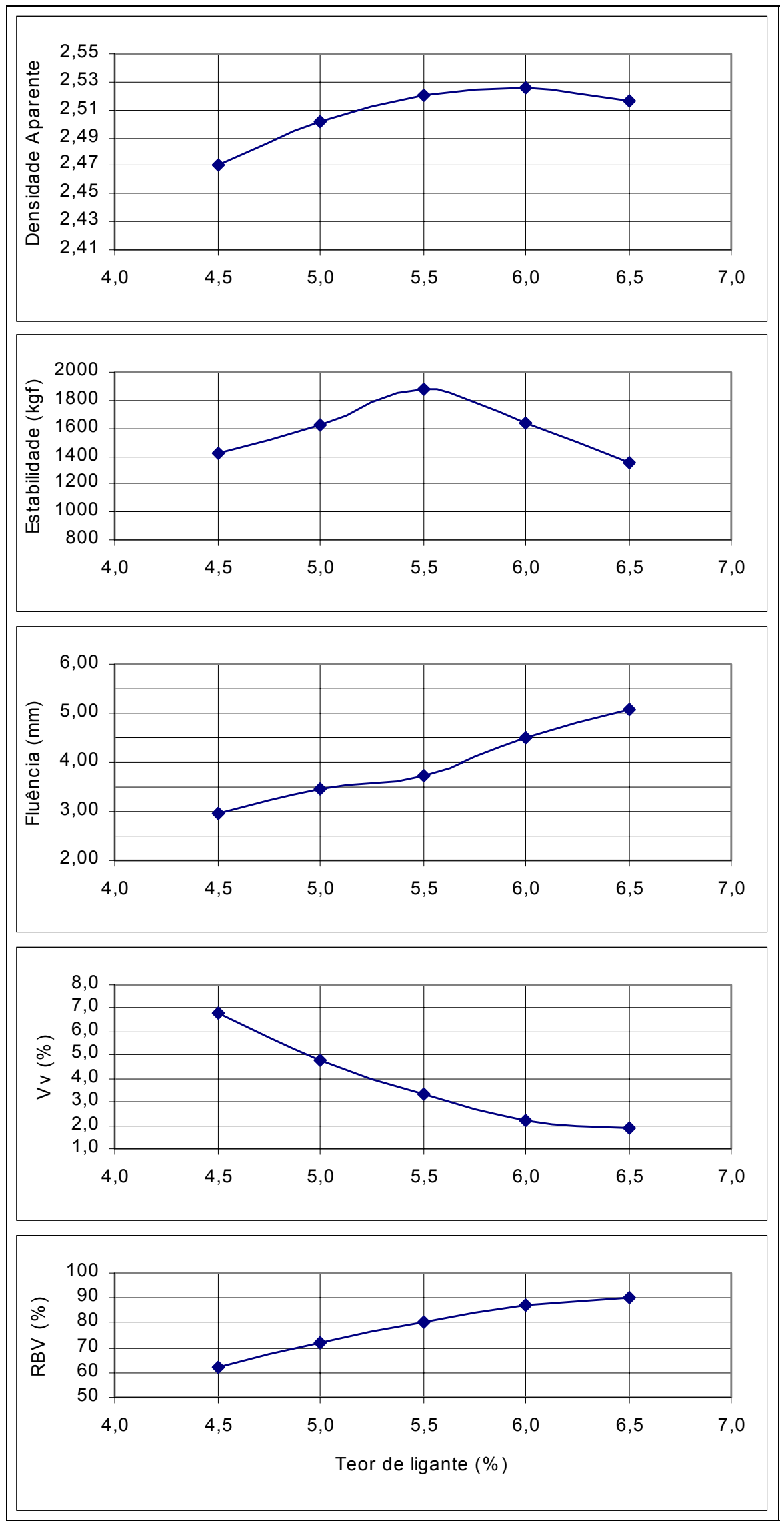

Figura 4.1 - Gráficos da dosagem Marshall para a mistura de referência (CBUQ-AC). 

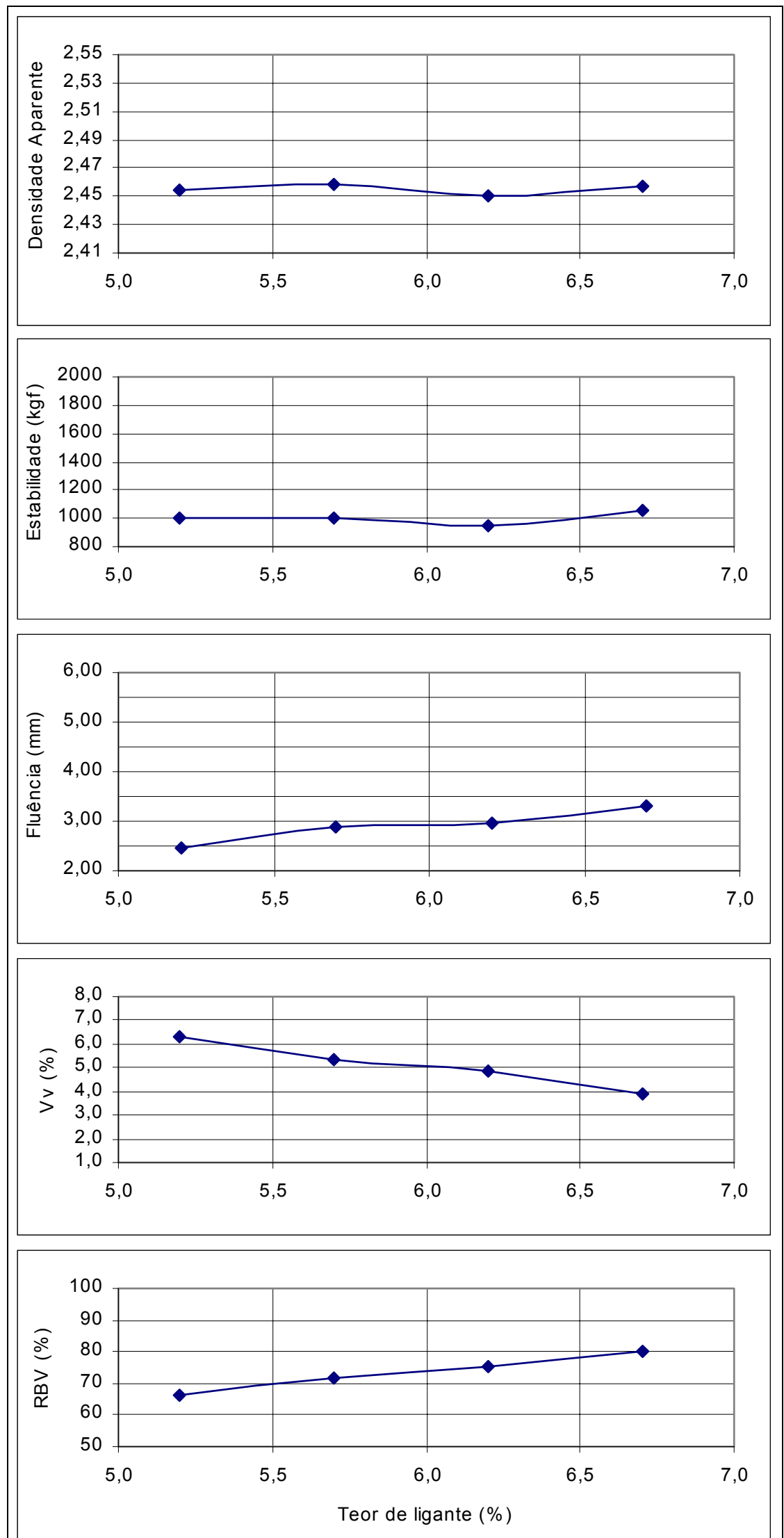

Figura 4.2 - Gráficos da dosagem Marshall da mistura SMA-AP. 

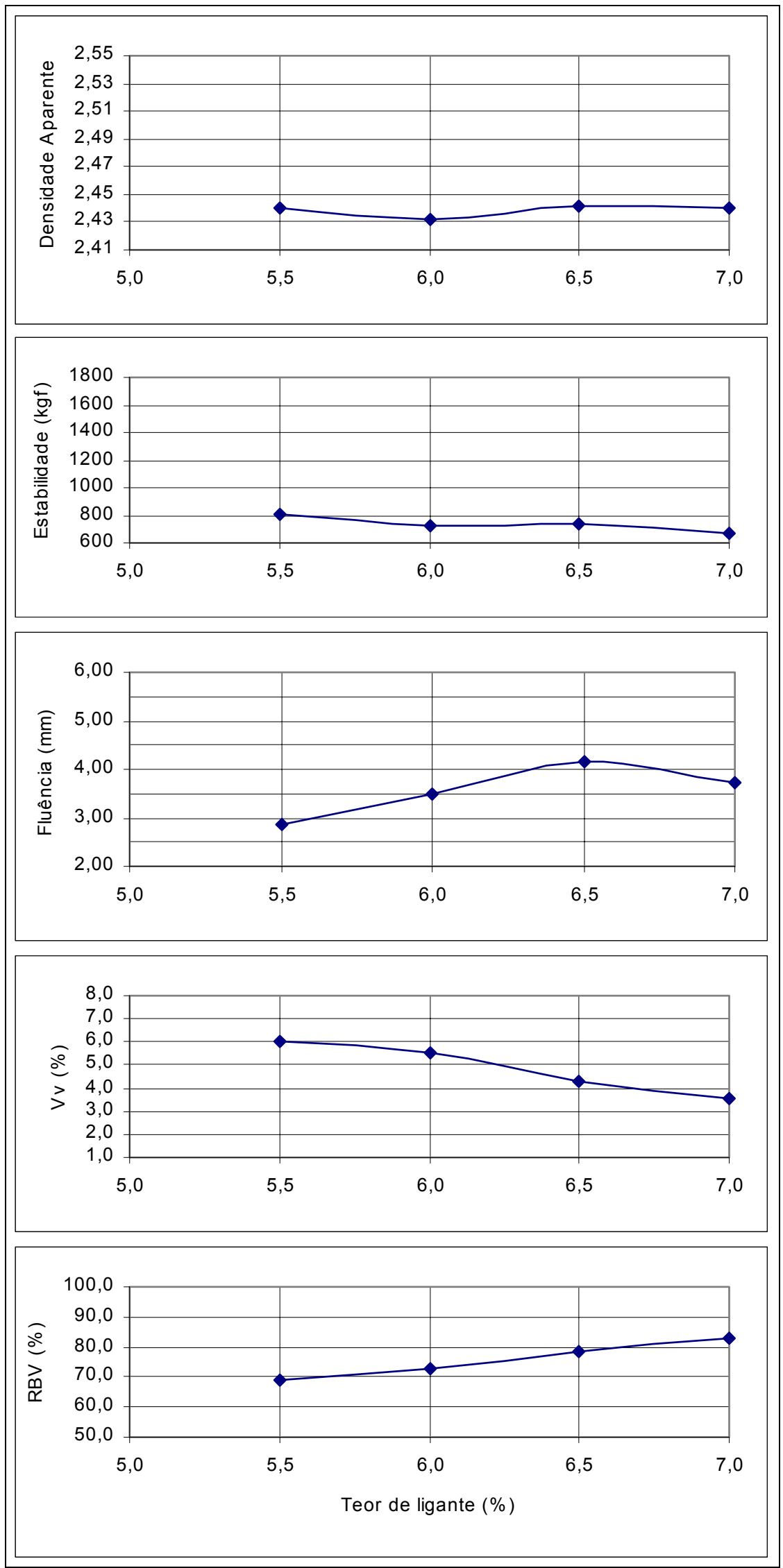

Figura 4.3 - Gráficos da dosagem Marshall da mistura SMA-AB. 
O valor do teor asfáltico de projeto selecionado para as misturas SMA foi de $6,5 \%$, correspondente a um volume de vazios bem próximo de $4 \%$ nas duas dosagens realizadas, com asfalto-polímero e com asfalto-borracha. A proximidade dos resultados de volume de vazios motivou a escolha de um teor único para as três misturas de SMA avaliadas neste trabalho. $O$ teor asfáltico escolhido atende às exigências da especificação DNER-ES 313/97 (Tabela 3.10).

Pôde-se calcular, então, a espessura média da película de ligante, considerandose os grãos esféricos e com mesmo diâmetro, igual ao valor médio do intervalo entre peneiras. No caso da mistura de referência, a espessura foi de 7,4 $\mu \mathrm{m}$, enquanto que para as misturas SMA foi de $11,3 \mu \mathrm{m}$, aproximadamente $50 \%$ maior que a do concreto asfáltico convencional. Uma película asfáltica mais espessa retarda o desgaste e, para evitar a exsudação do concreto asfáltico, são utilizadas fibras para impedir o escorrimento do ligante.

\subsection{Avaliação das Propriedades Mecânicas}

\subsubsection{Resistência a danos causados por umidade induzida}

O ensaio AASHTO T-283/99 (Resistance of Compacted Bituminous Mixture to Moisture Induced Damage) foi realizado no Laboratório de Tecnologia de Pavimentação da Escola Politécnica da USP (LTP-EPUSP), com corpos de prova da mistura de referência (CBUQ-AC), com teor asfáltico de projeto $(5,3 \%)$, porém com volume de vazios entre $6 \%$ e $8 \%$. Para se conseguir isso, os corpos de prova foram compactados com energia inferior, em torno de 18 golpes por face. Os resultados são apresentados na Tabela 4.6.

Os valores das resistências à tração ficaram bastante próximos, seja dos corpos de prova que foram submetidos ou não ao condicionamento, indicando que não houve perda de adesividade nas amostras com a indução de água. Portanto, pode-se concluir que a adesividade entre o agregado usado neste trabalho e o CAP 20 é satisfatória. Como isto ocorreu para a mistura mais susceptível à perda de adesividade (CBUQ-AC), constatou-se de que não havia a necessidade de realizar o ensaio para as outras misturas, já que a avaliação da adesividade não é o enfoque deste trabalho. 
Tabela 4.6 - Resultados do ensaio de resistência de misturas asfálticas compactadas a danos causados por umidade induzida.

\begin{tabular}{|c|c|c|c|c|c|c|c|}
\hline \multirow{2}{*}{ Corpos de Prova } & 1 & 2 & 3 & 4 & 5 & 6 & 7 \\
\hline & \multicolumn{3}{|c|}{ Com condicionamento } & \multicolumn{4}{|c|}{ Sem condicionamento } \\
\hline Volume de vazios (\%) & 6,92 & 6,77 & 7,44 & 7,20 & 6,52 & 7,51 & 7,34 \\
\hline Média do volume de vazios (\%) & \multicolumn{3}{|c|}{7,04} & \multicolumn{4}{|c|}{7,08} \\
\hline Grau de saturação (\%) & 56,9 & 59,9 & 62,4 & - & - & - & - \\
\hline Resistência à tração (MPa) & 1,187 & 1,305 & 1,267 & 1,231 & 1,225 & 1,185 & 1,180 \\
\hline Média da RT (MPa) & \multicolumn{3}{|c|}{1,253} & \multicolumn{4}{|c|}{1,205} \\
\hline RRT (\%) & \multicolumn{7}{|c|}{103,97} \\
\hline
\end{tabular}

\subsubsection{Resistência à tração e módulo de resiliência}

A resistência à tração e o módulo de resiliência foram ambos determinados por compressão diametral, seguindo as normas DNER ME-138/94 e DNER ME-133/94, respectivamente. Foram moldados corpos de prova no compactador Marshall para as quatro misturas, com os teores estabelecidos no item 4.1. As temperaturas de usinagem e compactação são apresentadas na Tabela 3.9. Os ensaios foram realizados no LTPEPUSP e a temperatura de ensaio foi de $25^{\circ} \mathrm{C}$.

A Tabela 4.7 e a Figura 4.4 apresentam os resultados do ensaio de resistência à tração indireta. Pode-se observar que as misturas SMA tiveram valores de resistência à tração dentro de uma mesma ordem de grandeza, com a mistura com polímero apresentando uma maior resistência à tração. A alta resistência apresentada pela mistura de referência não era esperada, fugindo um pouco dos valores usuais de misturas asfálticas convencionais.

Tabela 4.7 - Resistência à tração indireta por compressão diametral (MPa).

\begin{tabular}{|l|c|c|c|c|}
\hline \multicolumn{1}{|c|}{ Misturas } & \multicolumn{3}{c|}{ Resistência à Tração $($ MPa) } & Média (MPa) \\
\hline Faixa C + CAP 20 & 1,896 & 2,272 & 2,180 & 2,116 \\
\hline SMA + CAP 20 & 1,187 & 1,168 & 1,054 & 1,137 \\
\hline SMA + Asfalto com polímero & 1,591 & 1,543 & 1,565 & 1,567 \\
\hline SMA + Asfalto-borracha & 0,955 & 1,137 & 1,076 & 1,056 \\
\hline
\end{tabular}




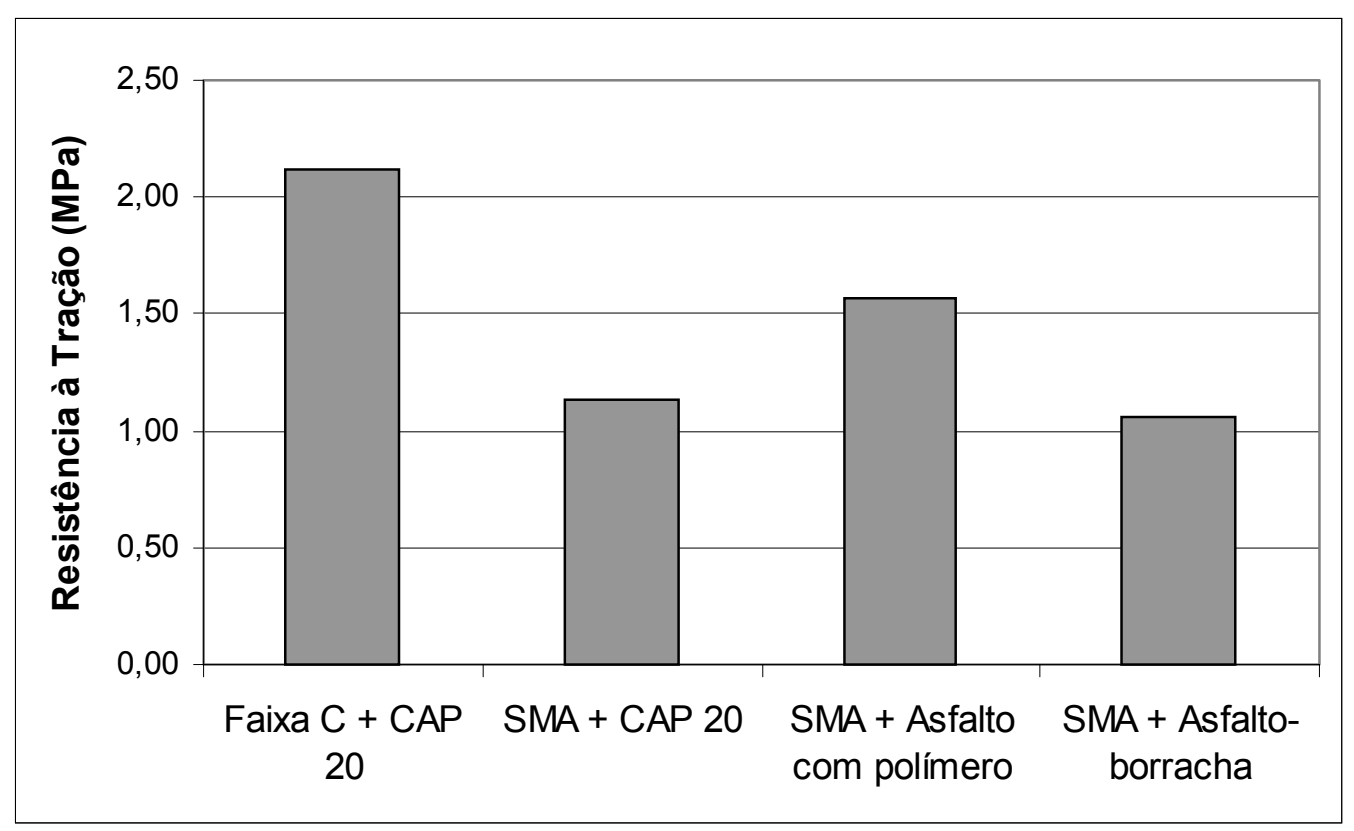

Figura 4.4 - Resultados do ensaio de resistência à tração por compressão diametral.

O ensaio de módulo de resiliência possui uma variação muito grande nos seus resultados. Essa variação é proporcionada por 3 fontes de erro: (a) erro experimental, dependente do equipamento em que se realiza o ensaio, principalmente do dispositivo de leitura dos deslocamentos; (b) erro devido à heterogeneidade do corpo de prova, com o resultado variando de acordo com a orientação em que o corpo de prova é ensaiado; (c) erro da amostra, variação entre corpos de prova de uma mesma mistura asfáltica, decorrente da difícil reprodutibilidade desse tipo de mistura.

Pesquisa realizada por BROWN \& FOO (1991) constatou que a maior fonte de erro é a baixa reprodutibilidade das misturas asfálticas, seguida do erro experimental. Com o intuito de diminuir o erro de heterogeneidade do corpo de prova, o ensaio foi feito com duas orientações $\left(0^{\circ}\right.$ e $\left.90^{\circ}\right)$, sendo considerados os dois resultados e extraída uma média.

Com objetivo de minimizar o efeito da principal fonte de erro, a baixa reprodutibilidade das misturas asfálticas, o ensaio foi realizado várias vezes para uma mesma mistura asfáltica. A Tabela 4.8 apresenta os resultados dos corpos de prova ensaiados para as quatro misturas asfálticas avaliadas neste trabalho. O gráfico da 
Figura 4.5 mostra a média dos resultados do ensaio de módulo de resiliência para cada mistura asfáltica.

Tabela 4.8 - Resultados do ensaio de módulo de resiliência.

\begin{tabular}{|l|c|c|c|c|c|c|}
\hline \multirow{2}{*}{ Misturas } & \multicolumn{5}{c|}{ Módulo de Resiliência (MPa) } & Média \\
(MPa)
\end{tabular}

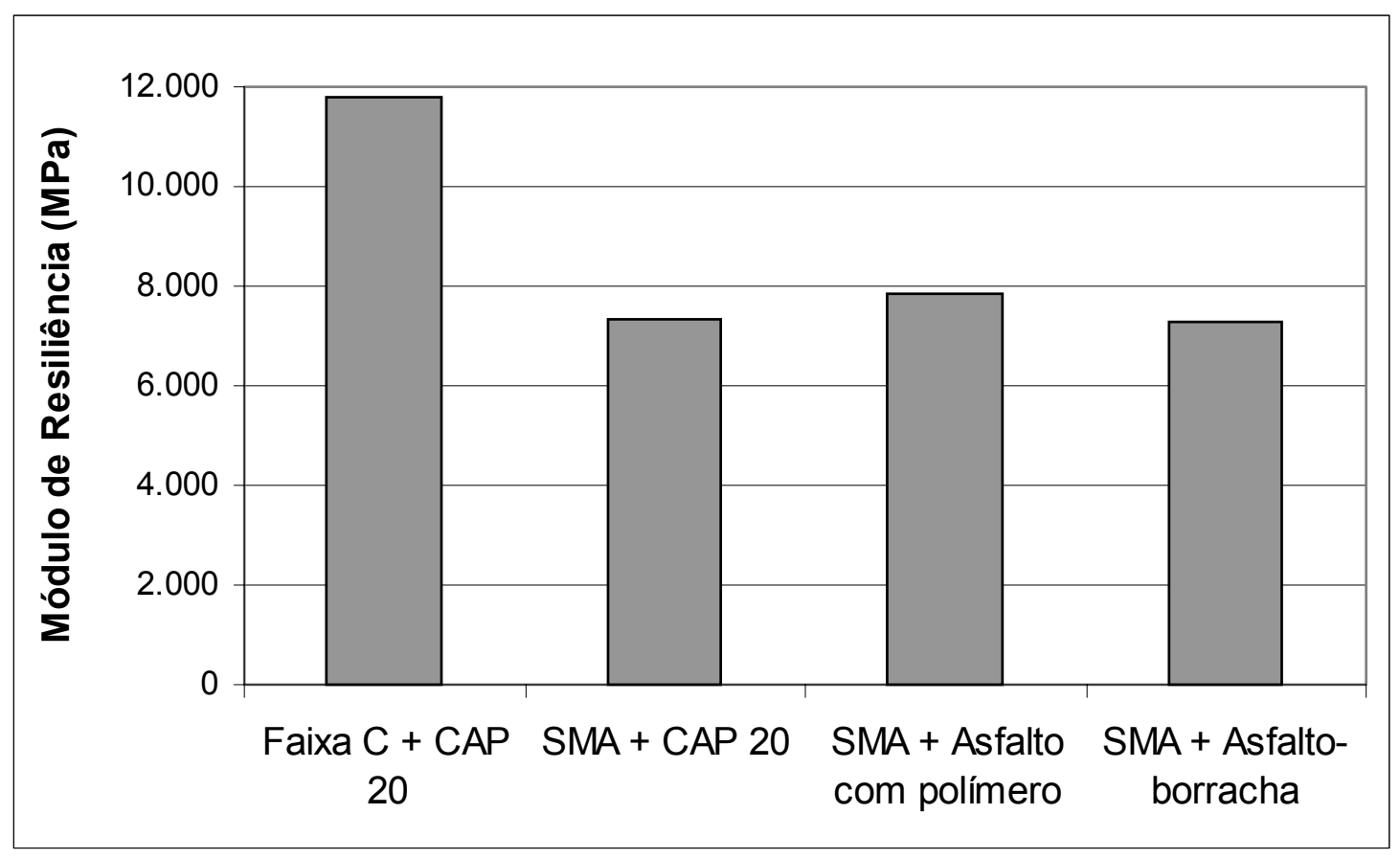

Figura 4.5 - Resultados do ensaio de módulo de resiliência.

Os valores de módulo de resiliência das misturas asfálticas SMA ficaram num mesmo patamar e a diferença entre eles está dentro da variação do ensaio, indicando que as misturas SMA apresentaram valores de módulo de resiliência na mesma ordem de grandeza de misturas asfálticas convencionais, não sendo, portanto, considerada uma mistura asfáltica rígida. 
A mistura de referência (CBUQ-AC) ensaiada para esta pesquisa teve um resultado de módulo de resiliência bem acima do esperado, assim como uma alta resistência à tração, fugindo do que uma mistura de Faixa C (DNER) com cimento asfáltico convencional está acostumada a apresentar.

Assim como a mistura de referência deste trabalho, algumas misturas asfálticas apresentam alta resistência à tração, acompanhadas de um alto valor de módulo de resiliência. Por conta disso, a relação entre o módulo de resiliência e a resistência à tração $(\mathrm{MR} / \mathrm{RT})$ permite avaliar o comportamento das misturas asfálticas com relação ao trincamento. Quanto menor o valor de MR/RT, melhor o comportamento mecânico da mistura, pois se une flexibilidade a uma boa resistência à tração. Uma diminuição da relação MR/RT pode ocasionar até a utilização de espessuras menores da camada de revestimento para uma mesma vida de fadiga. A Tabela 4.9 e a Figura 4.6 apresentam os resultados de MR/RT para cada mistura avaliada nesta pesquisa.

Tabela 4.9 - Relação entre o módulo de resiliência e a resistência à tração.

\begin{tabular}{|l|c|}
\hline \multicolumn{1}{|c|}{ Misturas } & MR/RT \\
\hline Faixa C + CAP 20 & 5.562 \\
\hline SMA + CAP 20 & 6.429 \\
\hline SMA + Asfalto com polímero & 5.002 \\
\hline SMA + Asfalto-borracha & 6.890 \\
\hline
\end{tabular}

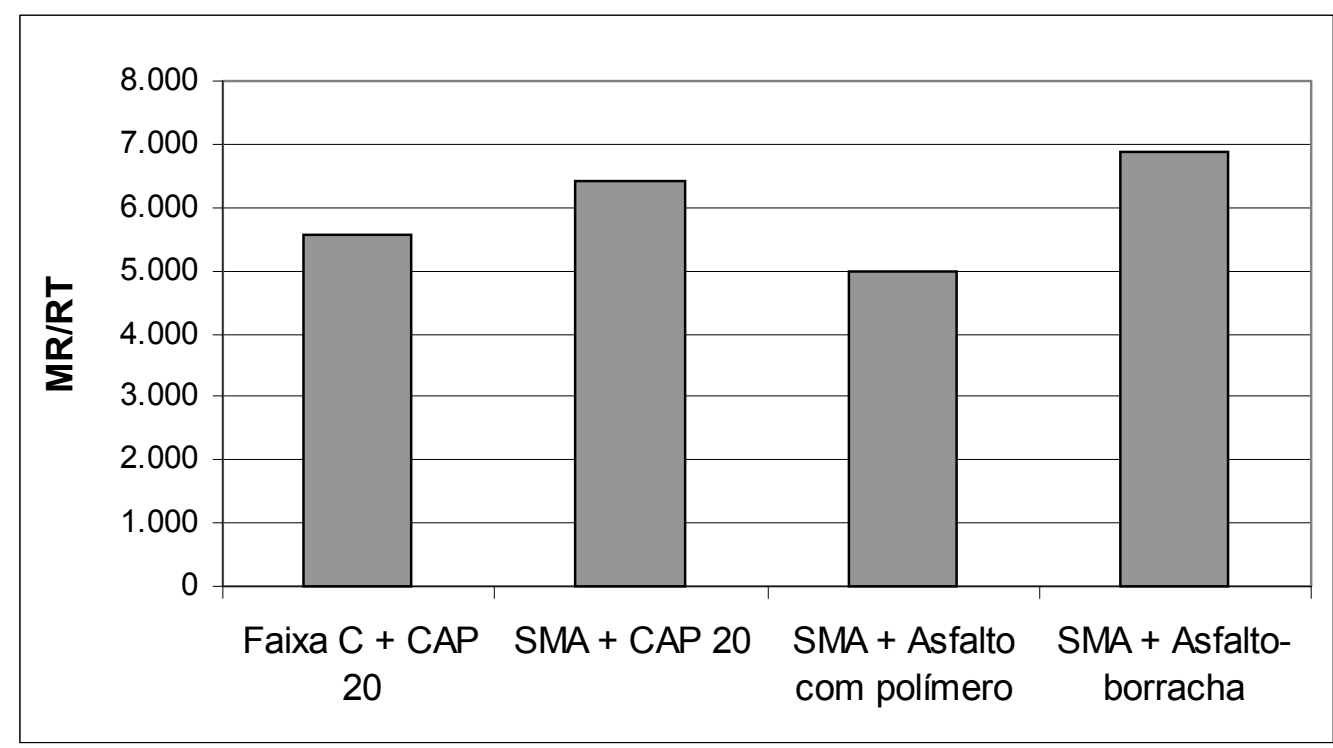

Figura 4.6 - Gráfico da relação MR/RT das misturas asfálticas avaliadas. 
Os valores da relação MR/RT mostram que a mistura de referência (CBUQ-AC) tem comportamento mecânico muito similar às misturas SMA. A mistura com asfalto modificado por polímero (SMA-AP) teve o melhor resultado, porém o uso de polímero só é justificado quando a diminuição da relação MR/RT ocasionar uma menor espessura de revestimento ou uma vida de fadiga mais extensa.

\subsubsection{Deformação permanente em trilha de roda}

As misturas asfálticas submetidas ao simulador de tráfego LCPC foram usinadas, compactadas e ensaiadas no Laboratório de Tecnologia de Pavimentação da Escola Politécnica da USP (LTP-EPUSP).

Após usinadas, as misturas SMA, principalmente a mistura com CAP convencional (SMA-AC), deixavam a impressão de excesso de ligante aderido ao recipiente do misturador. Posteriormente, as misturas asfálticas foram colocadas na estufa, para que fosse feito o envelhecimento de curto prazo, preconizado pelo procedimento AASHTO PP-2 (Standard Practice for Mixture Conditioning of Hot Mix Asphalt).

Foram compactadas duas placas para cada mistura avaliada na mesa compactadora LCPC. O processo de compactação ocorreu de forma satisfatória, minimizando a impressão de excesso de ligante percebida durante a usinagem. Apenas na moldagem de uma placa de mistura SMA-AC foi observada a dificuldade de compactação, que também apresentou problemas na simulação do tráfego e foi, conseqüentemente, descartada. A causa mais provável do problema foi o fato de que a mistura asfáltica se encontrava em uma temperatura inferior à de compactação.

Depois de compactadas, pôde-se observar a macrotextura das placas. As misturas SMA apresentavam uma macrotextura mais rugosa que a mistura de referência. Pôde-se notar, também, que os agregados graúdos ficaram recobertos com ligante, o que confirma a necessidade do tráfego inicial para desenvolver a microtextura.

As misturas asfálticas foram ensaiadas no simulador de tráfego LCPC a uma temperatura de $60^{\circ} \mathrm{C}$, sendo realizadas leituras dos afundamentos em 15 pontos da 
superfície das placas, a 100, 300, 1.000, 3.000, 10.000 e 30.000 ciclos, onde cada ciclo correspondente a duas passadas do pneu.

A simulação do tráfego utilizando o equipamento LCPC é feita com o objetivo de avaliar a deformação permanente em trilha de roda, mas o ensaio também permite avaliar o desempenho da mistura asfáltica quanto à exsudação e à desagregação. Apenas uma placa (mistura SMA-AC) apresentou problemas de desagregação, mesmo assim foram feitas todas as leituras. Porém, a perda excessiva de agregados levou a um resultado que não representava a deformação permanente, o que fez com que estes fossem descartados.

Os resultados do ensaio de deformação permanente no simulador de tráfego LCPC são apresentados nas Figuras 4.7 a 4.11. Com os gráficos plotados em escala logarítmica, fez-se a regressão da média entre duas placas, utilizando o programa computacional Microsoft Excel. Deve-se destacar que os ensaios apresentaram resultados satisfatórios, pois o coeficiente de determinação $\left(\mathrm{R}^{2}\right)$ das regressões ficou muito próximo de 1 (um). Além disso, os resultados de duas placas de uma mesma mistura ficaram bastante próximos. A regressão dos resultados é uma equação do tipo:

$Y=a \cdot N^{b}$

onde:

$\mathrm{Y}=$ deformação permanente na placa de concreto asfáltico;

$\mathrm{a}=$ coeficiente linear da regressão;

$\mathrm{N}=$ número de ciclos;

$\mathrm{b}=$ coeficiente linear da regressão.

A Tabela 4.10 apresenta um resumo dos resultados obtidos nos ensaios, bem como o coeficiente angular da curva de deformação permanente. Quanto menor for esse parâmetro, menor a potencialidade de um concreto asfáltico desenvolver altos valores de deformação permanente. 


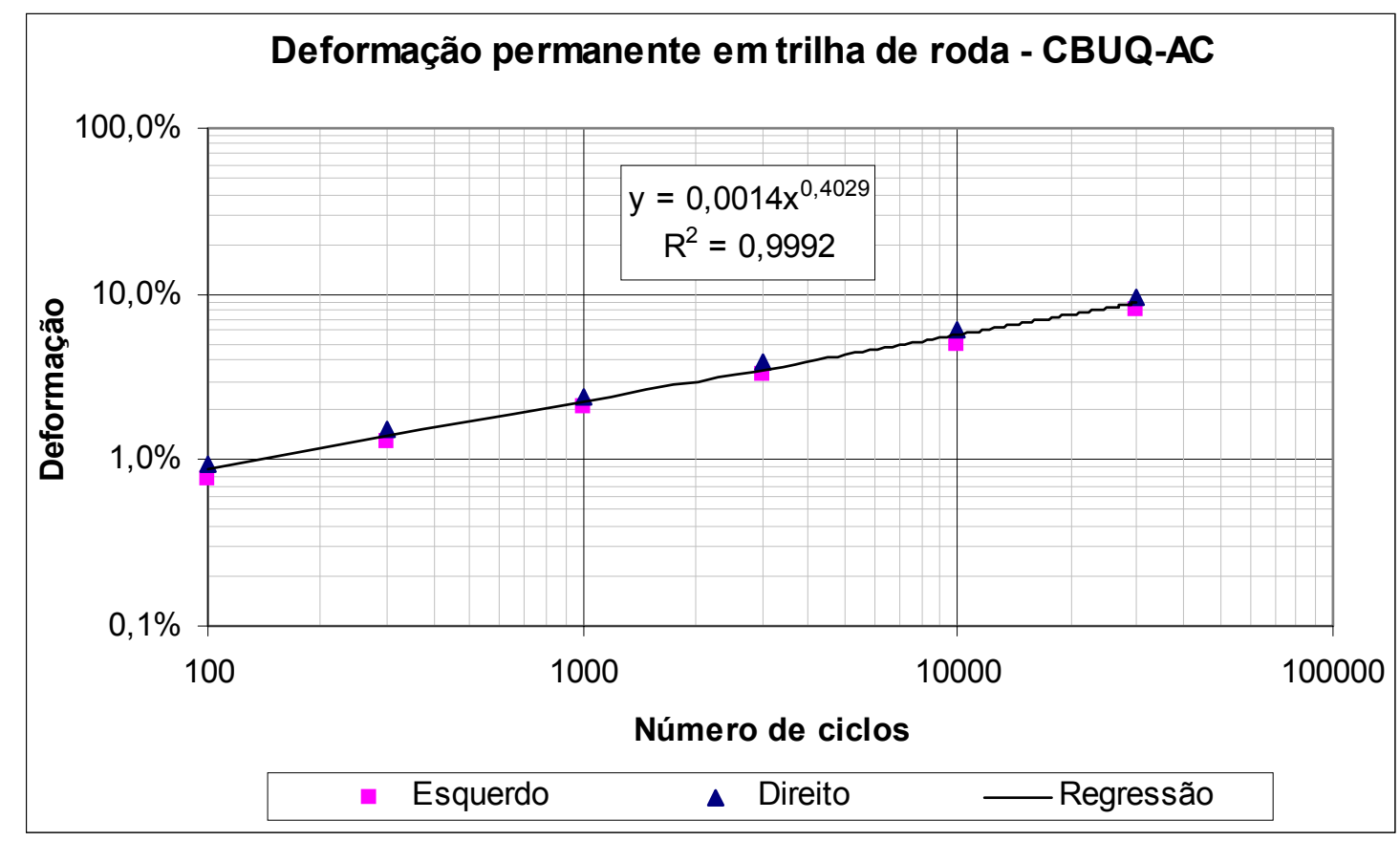

Figura 4.7 - Deformação permanente em trilha de roda - CBUQ-AC.

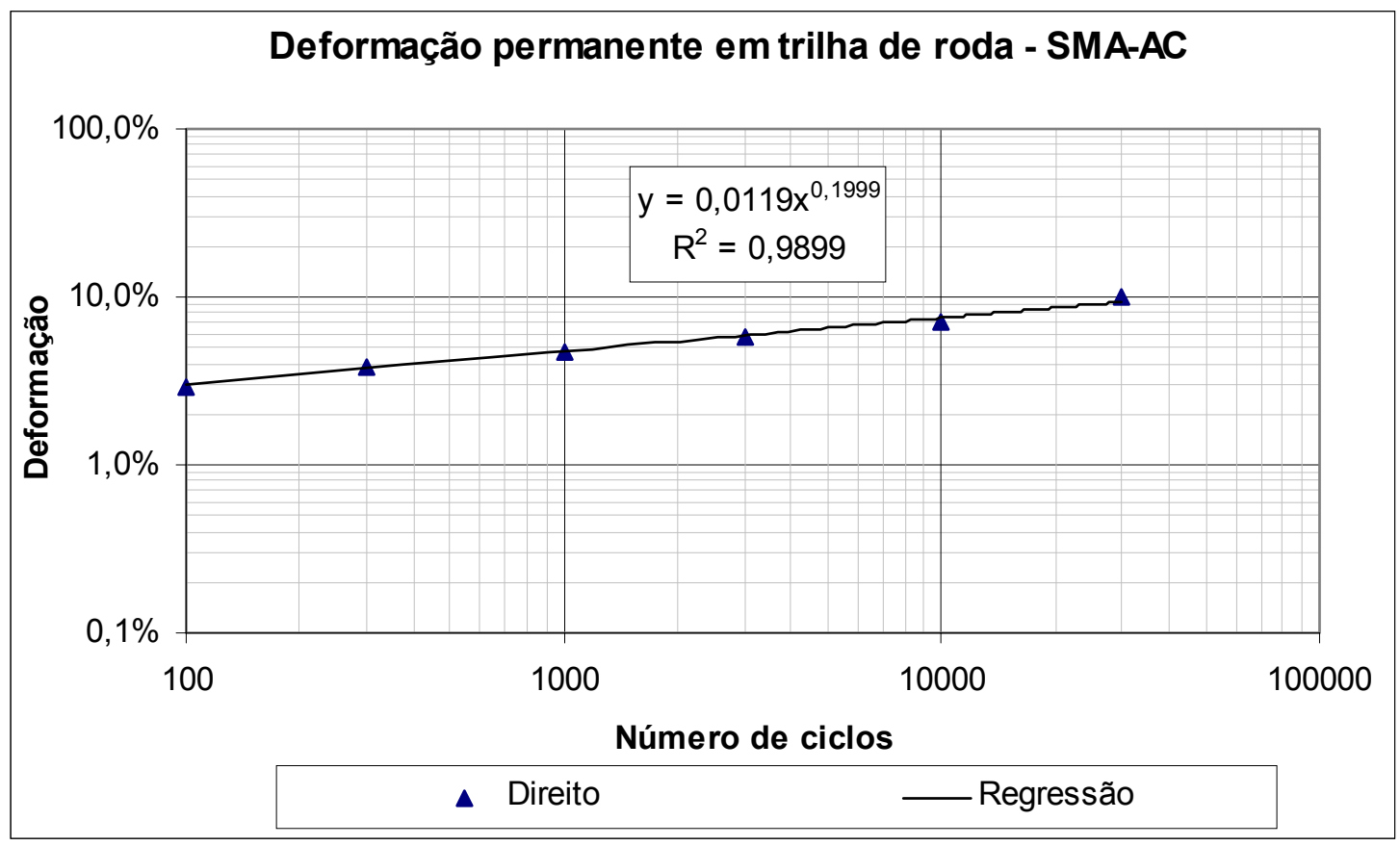

Figura 4.8 - Deformação permanente em trilha de roda - SMA-AC. 


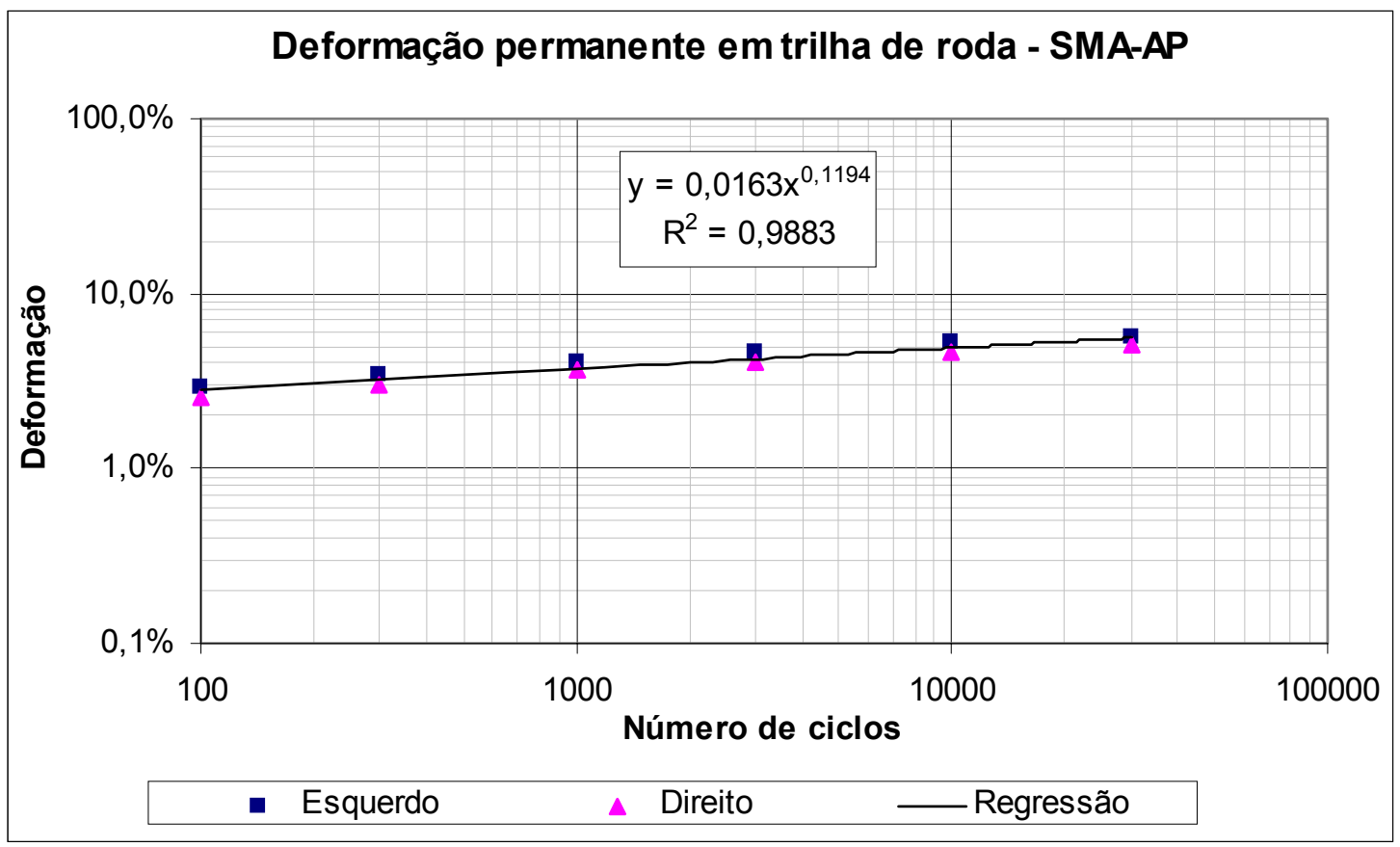

Figura 4.9 - Deformação permanente em trilha de roda - SMA-AP.

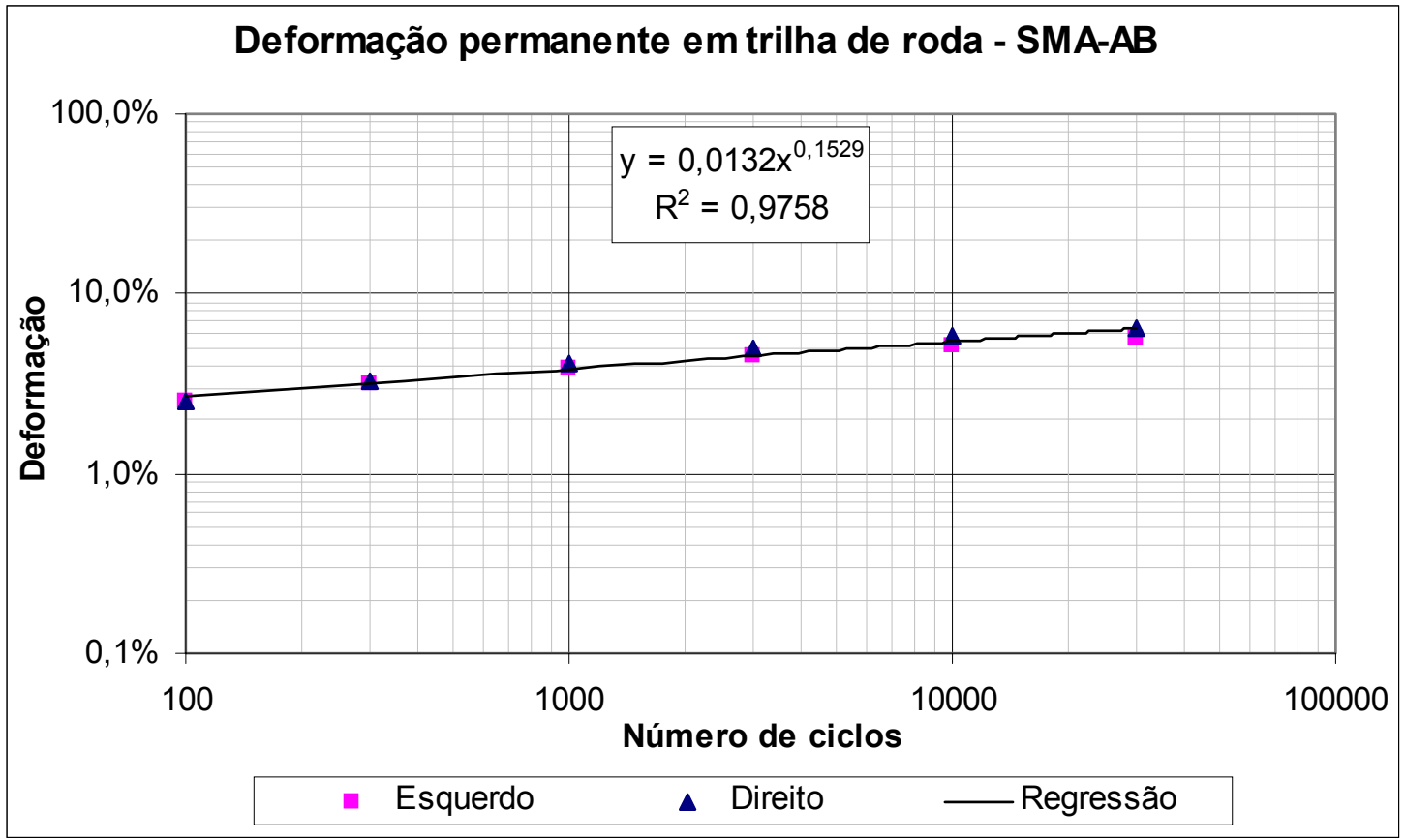

Figura 4.10 - Deformação permanente em trilha de roda - SMA-AB. 
Tabela 4.10 - Resultados do ensaio de deformação permanente em trilha de roda no simulador de tráfego LCPC.

\begin{tabular}{|c|c|c|c|c|c|}
\hline \multicolumn{2}{|r|}{ Misturas } & CBUQ-AC & SMA-AC & SMA-AP & SMA-AB \\
\hline \multirow{3}{*}{ 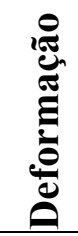 } & 1.000 ciclos & $2,25 \%$ & $4,76 \%$ & $3,85 \%$ & $3,95 \%$ \\
\hline & 10.000 ciclos & $5,57 \%$ & $7,03 \%$ & $4,94 \%$ & $5,53 \%$ \\
\hline & 30.000 ciclos & $8,85 \%$ & $9,85 \%$ & $5,39 \%$ & $5,98 \%$ \\
\hline \multicolumn{2}{|c|}{ Coeficiente Angular } & 0,4029 & 0,1999 & 0,1194 & 0,1529 \\
\hline
\end{tabular}

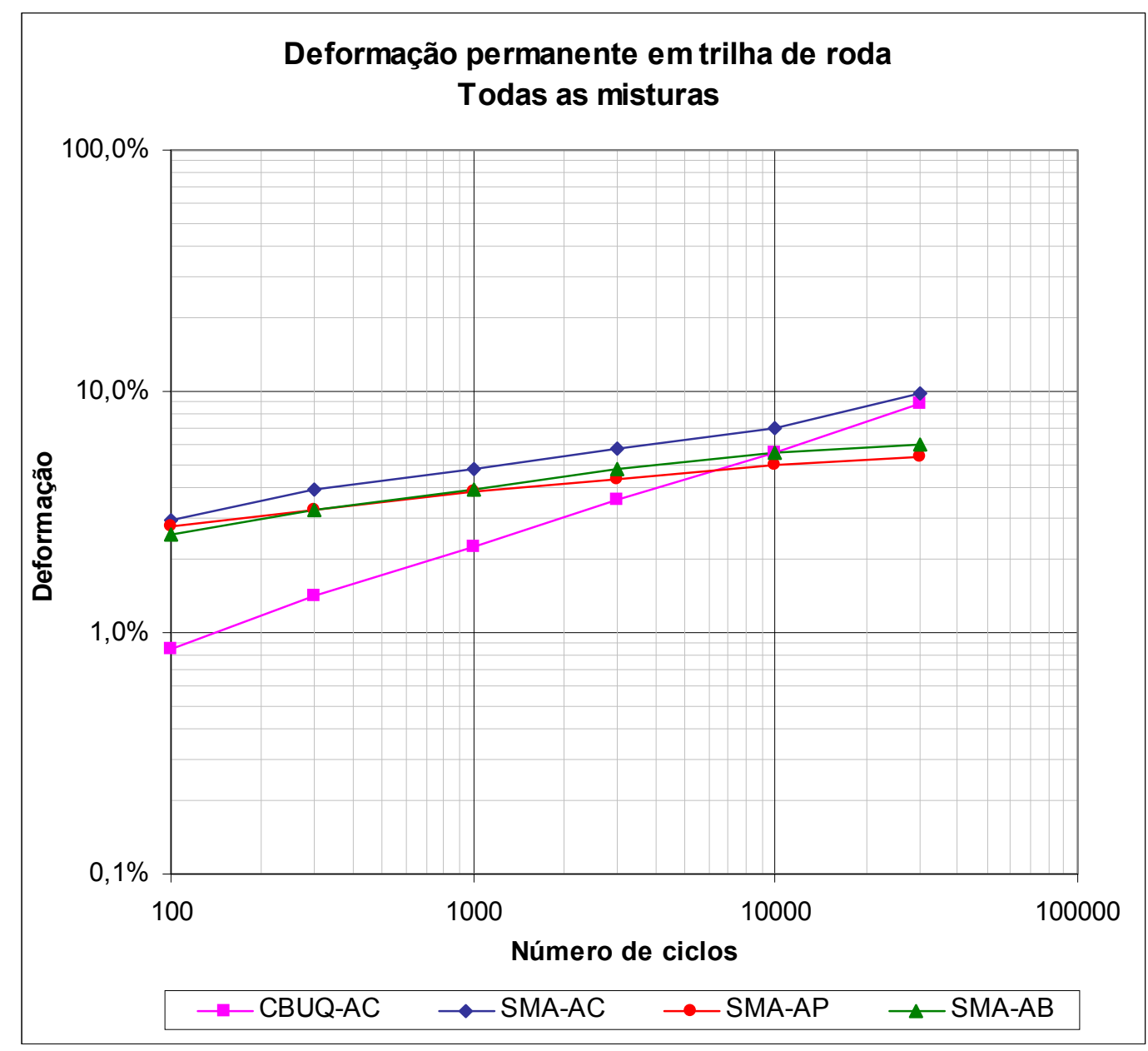

Figura 4.11 - Deformação permanente em trilha de roda - Todas as misturas.

Com base nos resultados obtidos, pode-se verificar o melhor desempenho das misturas asfálticas SMA quanto à resistência à deformação permanente em trilhas de roda. A mistura de referência (CBUQ-AC) teve um valor de deformação a 30.000 ciclos bastante próximo da mistura SMA-AC, porém o coeficiente angular foi bem mais elevado (aproximadamente o dobro). 
As misturas com outros tipos de ligante (asfalto com polímero e asfaltoborracha) tiveram os menores valores de deformação permanente. A grande diferença entre os coeficientes angulares das curvas de deformação permanente é condicionada, principalmente, pelo tipo de mistura (CBUQ ou SMA), ou seja, pela estrutura de agregados minerais. Por outro lado, a influência do tipo de ligante é verificada pela posição relativa das curvas, que mantêm um certo paralelismo, com menores valores de deformação permanente para o asfalto com polímero e para o asfalto-borracha.

\subsubsection{Ensaio de fadiga}

O ensaio de fadiga foi realizado com corpos de prova cilíndricos, idênticos aos dos ensaios de módulo de resiliência e de resistência à tração, também submetidos a carregamento diametral, sob temperatura de $25^{\circ} \mathrm{C}$. Foi realizado no LTP-EPUSP.

Com o valor de resistência à tração de cada mistura foram calculadas as cargas correspondentes aos diferentes níveis de tensão a que o corpo de prova seria submetido. Como a carga é aplicada ao corpo de prova através de um sistema pneumático, a partir da curva de calibração do equipamento chegou-se à pressão aplicada pelo pistão.

A Tabela 4.11 apresenta os resultados do ensaio de fadiga realizado com a mistura de referência (CBUQ-AC). Os corpos de prova foram submetidos a cinco níveis de tensão e, para cada um deles, foi contado o número de ciclos necessários para a ruptura (deslocamento superior a 3,5 mm). Foi plotado um gráfico do número de ciclos em função da diferença de tensões, em escala logarítmica, mostrado na Figura 4.12. Utilizando-se o programa computacional Microsoft Excel foi feita a regressão da curva de fadiga, obtendo-se a equação correspondente à curva.

Tabela 4.11 -Resultados do ensaio de fadiga - CBUQ-AC.

\begin{tabular}{|c|c|c|c|c|c|c|c|}
\hline $\mathbf{C P}$ & $\begin{array}{c}\text { Altura } \\
(\mathbf{c m})\end{array}$ & $\begin{array}{c}\text { Nível de } \\
\text { carregamento }\end{array}$ & $\begin{array}{c}\text { Carga } \\
(\mathbf{k g f})\end{array}$ & $\begin{array}{c}\text { Press. Man. } \\
\left(\mathbf{k g f} / \mathbf{c m}^{2}\right)\end{array}$ & $\begin{array}{c}\text { Número } \\
\mathbf{d e} \text { ciclos }\end{array}$ & $\begin{array}{c}\sigma_{\mathbf{t}} \\
(\mathbf{M P a})\end{array}$ & $\begin{array}{c}\Delta \sigma \\
(\mathbf{M P a})\end{array}$ \\
\hline 07 & 6,0 & $15 \%$ & 310,0 & 2,76 & 18165 & 0,317 & 1,270 \\
\hline 08 & 6,0 & $20 \%$ & 413,3 & 3,57 & 10684 & 0,423 & 1,693 \\
\hline 09 & 6,0 & $30 \%$ & 620,0 & 5,18 & 985 & 0,635 & 2,539 \\
\hline 10 & 6,0 & $40 \%$ & 826,7 & 6,79 & 330 & 0,846 & 3,386 \\
\hline 11 & 6,0 & $50 \%$ & 1033,3 & 8,41 & 135 & 1,058 & 4,232 \\
\hline
\end{tabular}




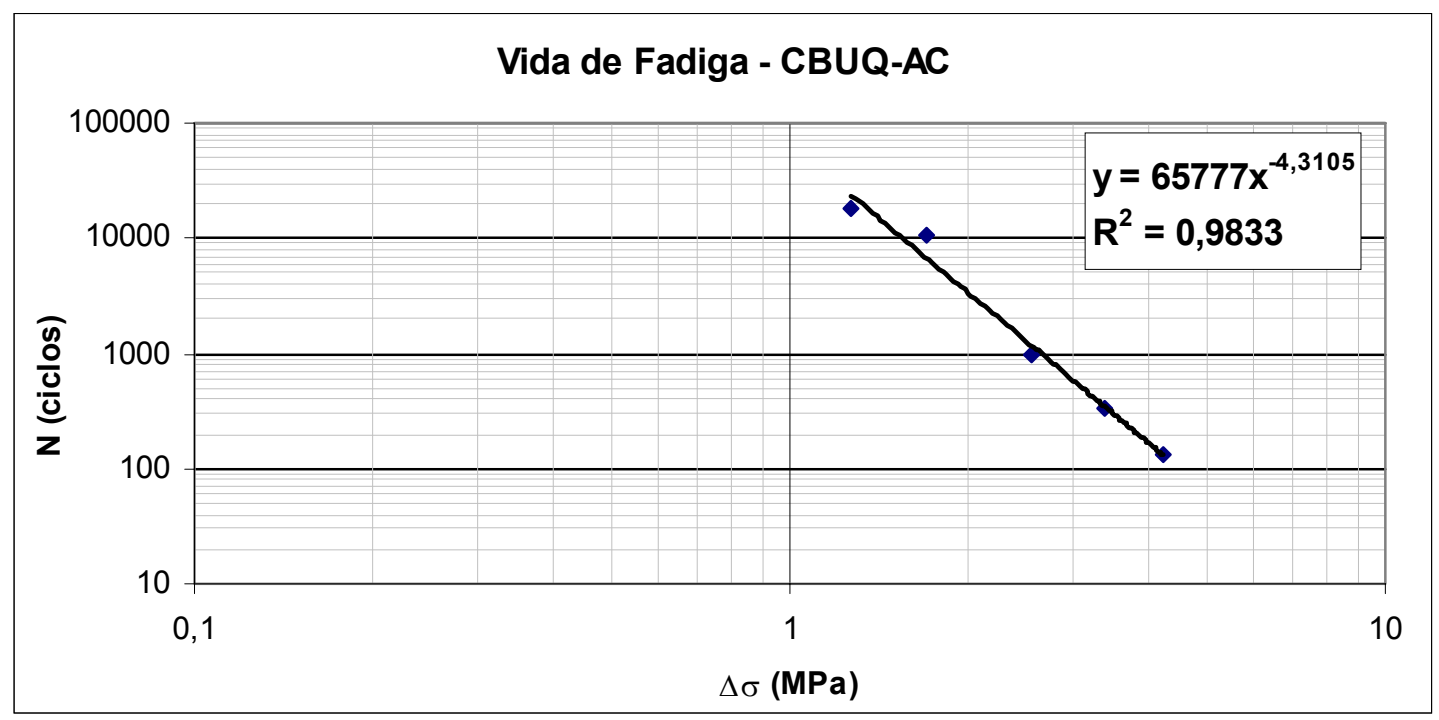

Figura 4.12 - Gráfico do ensaio de fadiga - CBUQ-AC.

O mesmo procedimento foi seguido para as outras misturas asfálticas avaliadas neste trabalho, a fim de se efetuar comparações com os parâmetros obtidos através das regressões. Nas Tabelas 4.12, 4.13 e 4.14 são apresentados os resultados do ensaio de fadiga realizado para as misturas asfálticas SMA com os três tipos de ligante avaliados neste trabalho. Com os resultados dos ensaios de fadiga para cada mistura, foram plotados os gráficos com as respectivas curvas de fadiga e feitas as regressões de cada curva. As regressões das curvas de fadiga seguem a Equação 4.2, quais as quais são obtidos parâmetros de fadiga ("k" e " $n$ ") para cada mistura asfáltica avaliada, conforme resumido na Tabela 4.15 .

$N=k \cdot\left(\frac{1}{\Delta \sigma}\right)^{n}$

Tabela 4.12 - Resultados do ensaio de fadiga - SMA-AC.

\begin{tabular}{|c|c|c|c|c|c|c|c|}
\hline $\mathbf{C P}$ & $\begin{array}{c}\text { Altura } \\
(\mathbf{c m})\end{array}$ & $\begin{array}{c}\text { Nível de } \\
\text { carregamento }\end{array}$ & $\begin{array}{c}\text { Carga } \\
(\mathbf{k g f})\end{array}$ & $\begin{array}{c}\text { Press. Man. } \\
\left(\mathbf{k g f} / \mathbf{c m}^{2}\right)\end{array}$ & $\begin{array}{c}\text { Número } \\
\mathbf{d e ~ c i c l o s}\end{array}$ & $\begin{array}{c}\sigma_{\mathbf{t}} \\
(\mathbf{M P a})\end{array}$ & $\begin{array}{c}\Delta \sigma \\
(\mathbf{M P a})\end{array}$ \\
\hline 04 & 6,79 & $10 \%$ & 125,6 & 1,33 & 28257 & 0,114 & 0,455 \\
\hline 08 & 6,70 & $20 \%$ & 248,0 & 2,28 & 3201 & 0,227 & 0,909 \\
\hline 05 & 6,71 & $30 \%$ & 372,5 & 3,25 & 331 & 0,341 & 1,364 \\
\hline 12 & 6,70 & $40 \%$ & 495,9 & 4,21 & 126 & 0,455 & 1,819 \\
\hline 07 & 6,70 & $50 \%$ & 619,9 & 5,18 & 53 & 0,568 & 2,273 \\
\hline
\end{tabular}


Tabela 4.13 - Resultados do ensaio de fadiga - SMA-AP.

\begin{tabular}{|c|c|c|c|c|c|c|c|}
\hline $\mathbf{C P}$ & $\begin{array}{c}\text { Altura } \\
(\mathbf{c m})\end{array}$ & $\begin{array}{c}\text { Nível de } \\
\text { carregamento }\end{array}$ & $\begin{array}{c}\text { Carga } \\
(\mathbf{k g f})\end{array}$ & $\begin{array}{c}\text { Press. Man. } \\
\left(\mathbf{k g f} / \mathbf{c m}^{\mathbf{2}} \mathbf{)}\right.\end{array}$ & $\begin{array}{c}\text { Número } \\
\mathbf{d e} \text { ciclos }\end{array}$ & $\begin{array}{c}\sigma_{\mathbf{t}} \\
(\mathbf{M P a})\end{array}$ & $\begin{array}{c}\Delta \sigma \\
(\mathbf{M P a})\end{array}$ \\
\hline 05 & 6,24 & $10 \%$ & 159,1 & 1,59 & 66666 & 0,157 & 0,627 \\
\hline 04 & 6,28 & $20 \%$ & 320,3 & 2,84 & 1829 & 0,313 & 1,253 \\
\hline 09 & 6,25 & $30 \%$ & 478,1 & 4,08 & 187 & 0,470 & 1,880 \\
\hline 08 & 6,25 & $40 \%$ & 637,5 & 5,32 & 122 & 0,627 & 2,506 \\
\hline 07 & 6,25 & $50 \%$ & 796,9 & 6,56 & 38 & 0,783 & 3,133 \\
\hline
\end{tabular}

Tabela 4.14 - Resultados do ensaio de fadiga - SMA-AB.

\begin{tabular}{|c|c|c|c|c|c|c|c|}
\hline $\mathbf{C P}$ & $\begin{array}{c}\text { Altura } \\
\mathbf{( c m )}\end{array}$ & $\begin{array}{c}\text { Nível de } \\
\text { carregamento }\end{array}$ & $\begin{array}{c}\text { Carga } \\
\mathbf{( k g f )}\end{array}$ & $\begin{array}{c}\text { Press. Man. } \\
\mathbf{( k g f / \mathbf { c m } ^ { 2 } )}\end{array}$ & $\begin{array}{c}\text { Número } \\
\mathbf{d e ~ c i c l o s ~}\end{array}$ & $\begin{array}{c}\sigma_{\mathbf{t}} \\
(\mathbf{M P a})\end{array}$ & $\begin{array}{c}\Delta \sigma \\
\mathbf{( M P a})\end{array}$ \\
\hline 05 & 6,3 & $15 \%$ & 162,4 & 1,61 & 9573 & 0,158 & 0,634 \\
\hline 06 & 6,3 & $20 \%$ & 216,6 & 2,03 & 3070 & 0,211 & 0,845 \\
\hline 07 & 6,3 & $30 \%$ & 324,9 & 2,88 & 871 & 0,317 & 1,267 \\
\hline 08 & 6,3 & $40 \%$ & 433,1 & 3,72 & 486 & 0,422 & 1,689 \\
\hline 09 & 6,3 & $50 \%$ & 541,4 & 4,57 & 144 & 0,528 & 2,112 \\
\hline
\end{tabular}

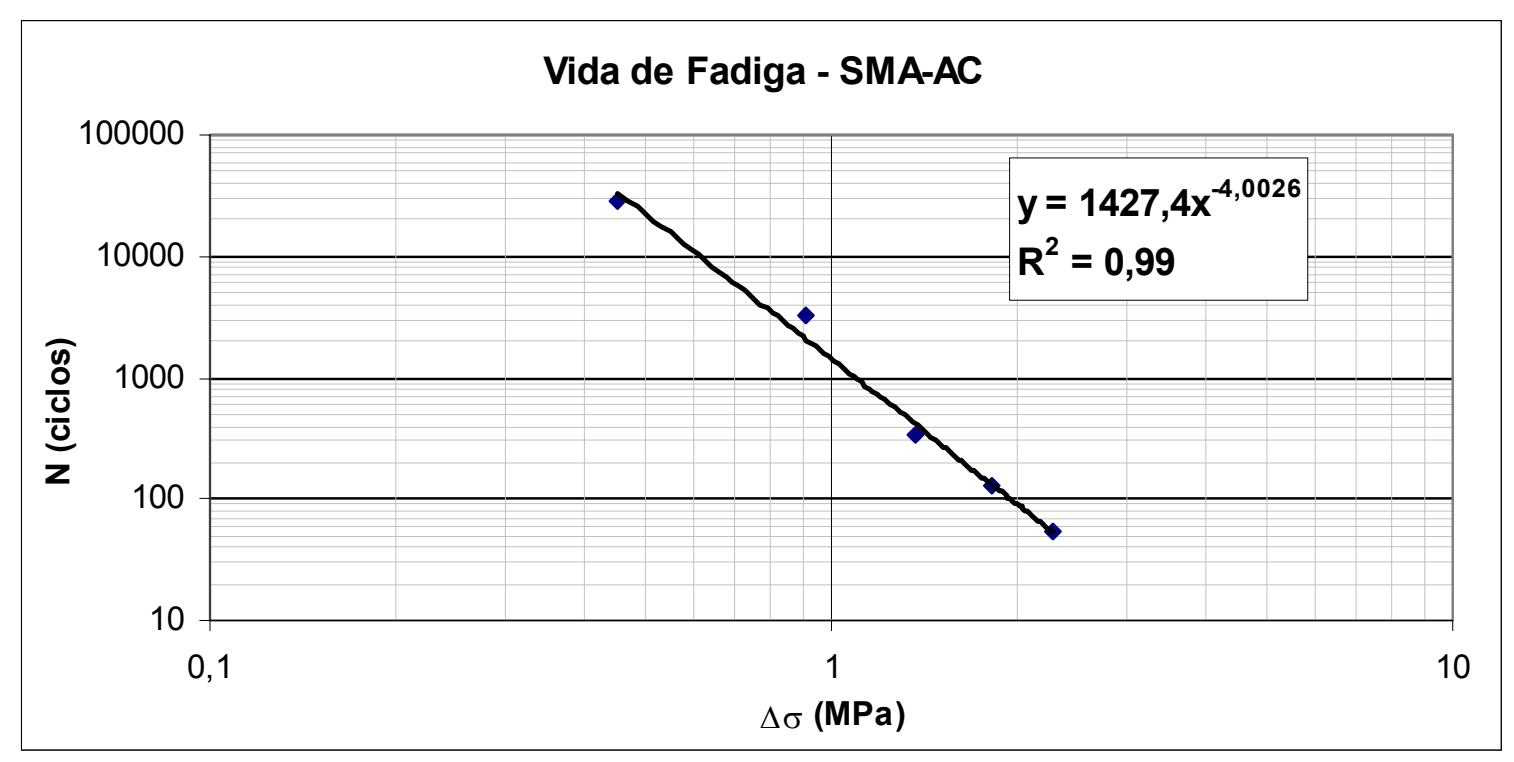

Figura 4.13 - Gráfico do ensaio de fadiga - SMA-AC. 


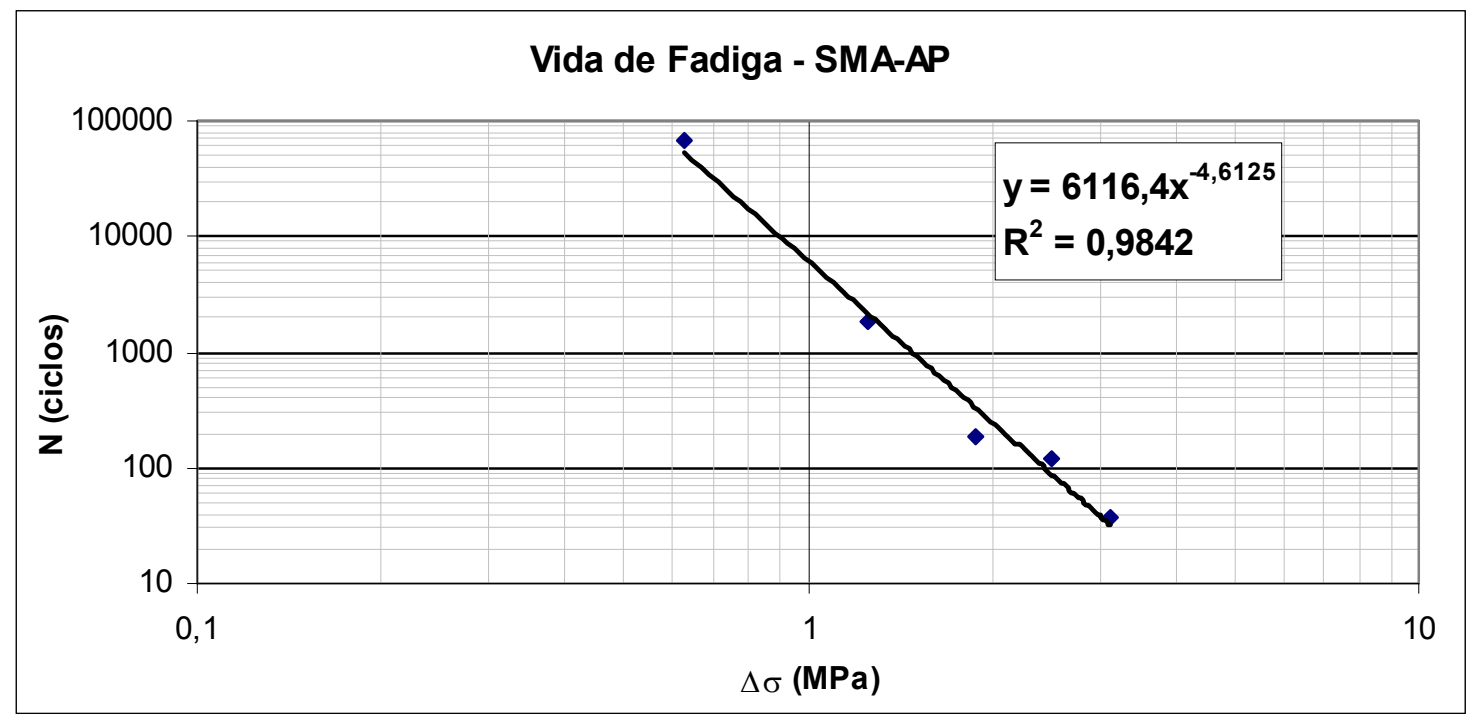

Figura 4.14 - Gráfico do ensaio de fadiga - SMA-AP.

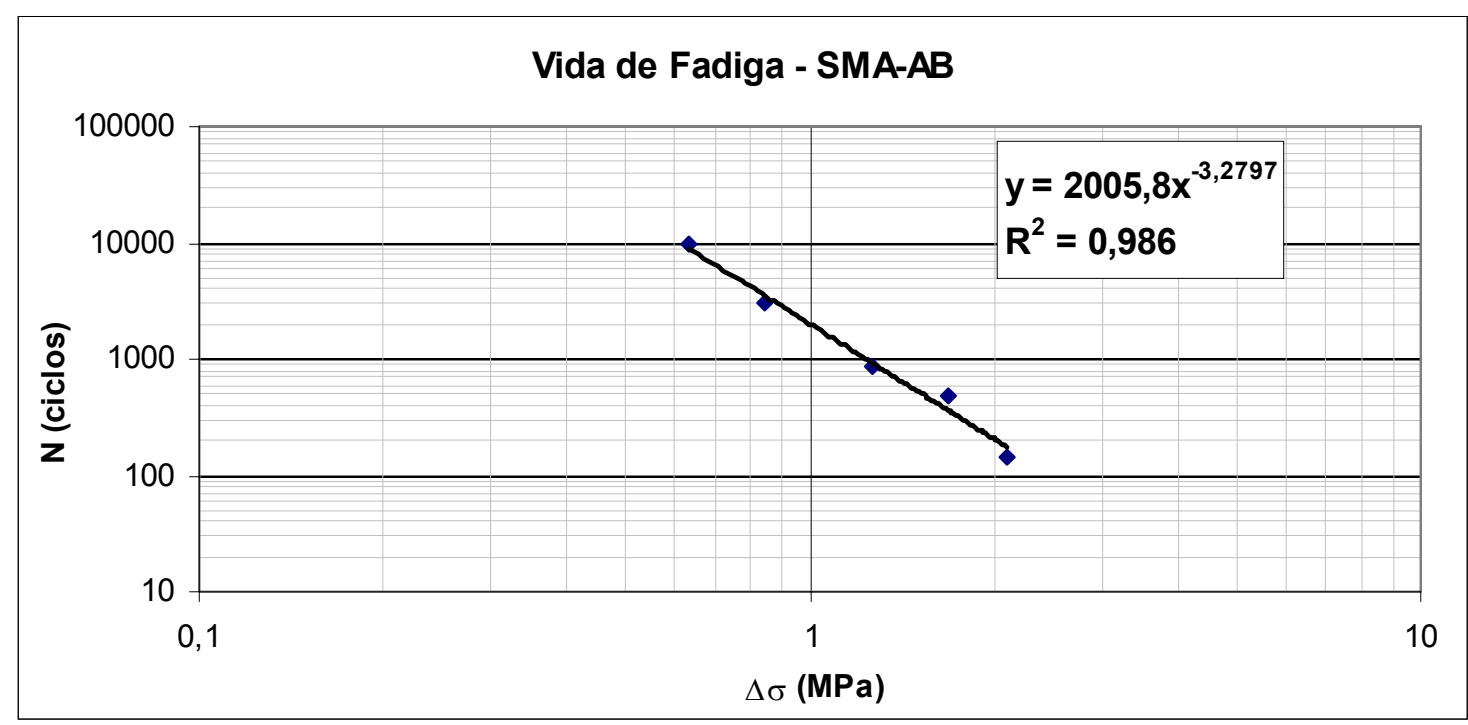

Figura 4.15 - Gráfico do ensaio de fadiga - SMA-AB.

Tabela 4.15 - Parâmetros de fadiga das misturas asfálticas avaliadas.

\begin{tabular}{|l|c|c|}
\hline \multicolumn{1}{|c|}{ Misturas } & k & n \\
\hline Faixa C + CAP 20 & 65.777 & 4,3105 \\
\hline SMA + CAP 20 & 1.427 & 4,0026 \\
\hline SMA + Asfalto com polímero & 6.116 & 4,6125 \\
\hline SMA + Asfalto-borracha & 2.006 & 3,2797 \\
\hline
\end{tabular}


A Figura 4.16 mostra as curvas de fadiga das quatro misturas avaliadas, dessa forma facilita-se a comparação do desempenho das misturas com relação à resistência ao aparecimento de trincas por fadiga.

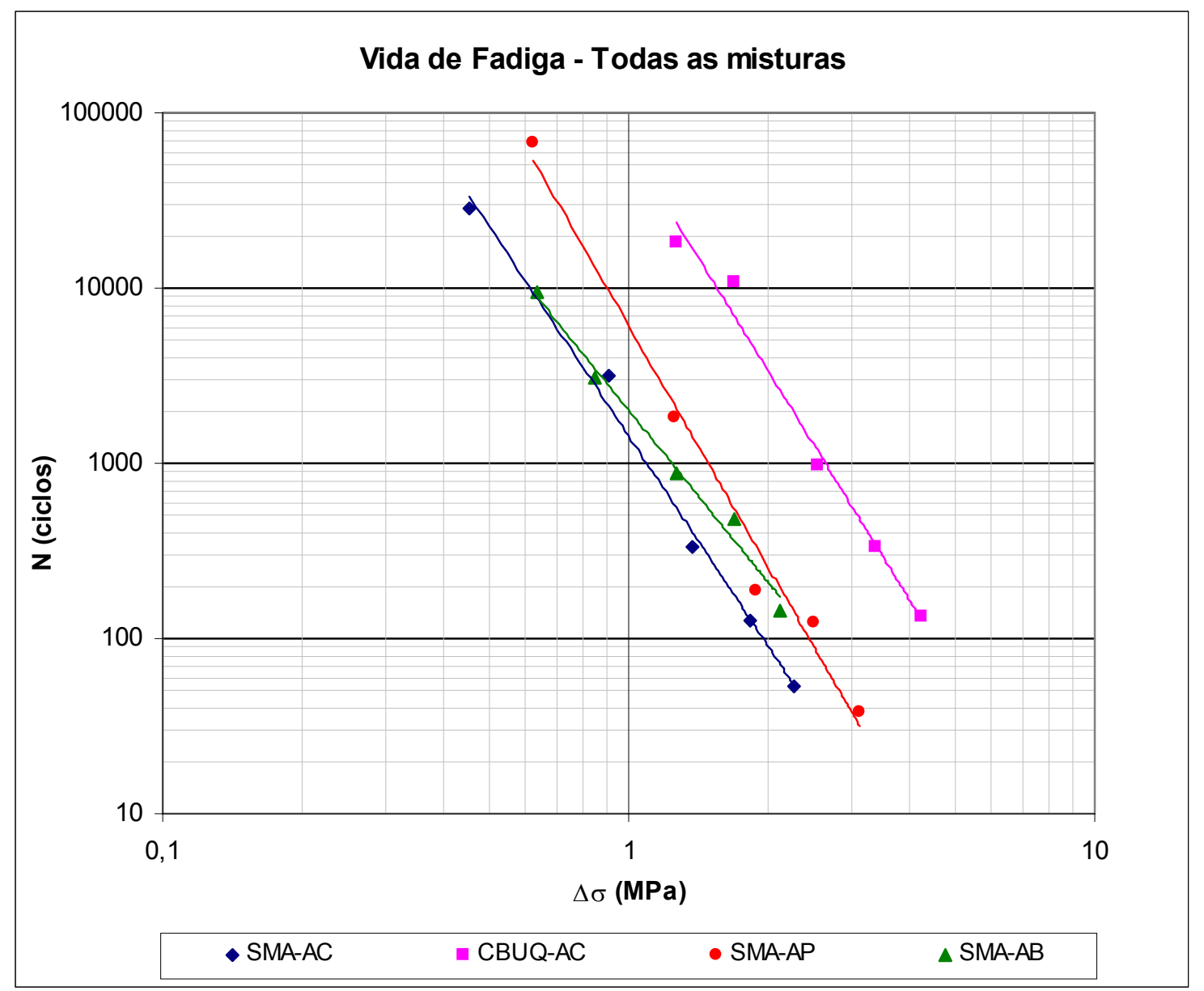

Figura 4.16 - Gráfico do ensaio de fadiga - Todas as misturas.

Com os resultados obtidos, pode-se fazer uma comparação das misturas asfálticas avaliadas através de uma simulação de uma estrutura hipotética. As camadas de base e sub-base foram supostas granulares, caracterizando um pavimento flexível. As quatro misturas asfálticas estudadas neste trabalho tiveram um alto valor de módulo de resiliência, o que sugere a necessidade de uma camada de ligação (binder) entre o revestimento e as camadas granulares. Dessa forma, propôs-se a estrutura apresentada na Tabela 4.16.

A análise tensional foi feita com o programa computacional ELSYM 5 e os resultados são apresentados na Tabela 4.17. 
Tabela 4.16 - Estrutura hipotética.

\begin{tabular}{|c|c|c|c|}
\hline Camadas & $\begin{array}{c}\text { Espessura } \\
(\mathbf{c m})\end{array}$ & $\begin{array}{c}\text { Coeficiente } \\
\text { de Poisson }\end{array}$ & $\begin{array}{c}\text { MR } \\
\text { (MPa) }\end{array}$ \\
\hline Revestimento asfáltico & 8 & 0,30 & variável \\
\hline Binder & 12 & 0,35 & 2.500 \\
\hline Base granular & 15 & 0,35 & 250 \\
\hline Sub-base granular & 20 & 0,35 & 230 \\
\hline Subleito & - & 0,45 & 100 \\
\hline
\end{tabular}

Tabela 4.17 - Resultados da estrutura hipotética.

\begin{tabular}{|c|c|c|c|c|c|}
\hline Misturas & MR (MPa) & $\sigma_{\mathbf{t}}(\mathbf{M P a})$ & $\sigma_{\mathbf{c}}(\mathbf{M P a})$ & $\Delta \sigma(\mathbf{M P a})$ & $\mathbf{N}$ \\
\hline CBUQ-AC & 11.770 & 0,636 & $-0,275$ & 0,911 & 98.299 \\
\hline SMA-AC & 7.308 & 0,295 & $-0,319$ & 0,614 & 10.053 \\
\hline SMA-AP & 7.836 & 0,339 & $-0,312$ & 0,651 & 44.055 \\
\hline SMA-AB & 7.275 & 0,292 & $-0,319$ & 0,611 & 10.094 \\
\hline
\end{tabular}

onde:

$\mathrm{MR}=$ módulo de resiliência obtido no ensaio de laboratório;

$\sigma_{\mathrm{t}}=$ tensão de tração no revestimento obtida no programa ELSYM 5;

$\sigma_{\mathrm{c}}=$ tensão de compressão no revestimento obtida no programa ELSYM 5;

$\Delta \sigma=$ diferença entre as tensões de tração e compressão $\left(\sigma_{t}-\sigma_{c}\right)$;

$\mathrm{N}=$ número de ciclos calculado pela equação 4.2 com os parâmetros da Tabela 4.15.

As regressões das curvas de fadiga tiveram um R-quadrado alto, muito próximo de 1 (um), indicando que os resultados dos ensaios foram satisfatórios do ponto de vista laboratorial.

Como se pode ver, não ficou evidenciado um desempenho superior do SMA quanto à resistência à fadiga. $\mathrm{O}$ que se verificou foi um melhor resultado da mistura de referência (CBUQ-AC), bem acima do que se espera para uma mistura desse tipo. No entanto, as misturas SMA tiveram um desempenho satisfatório se comparadas a misturas asfálticas com curva de fadiga publicadas na literatura (PINTO, 1991; MOTTA et al., 2002, etc). 


\section{CONCLUSÕES E SUGESTÕES PARA TRABALHOS FUTUROS}

\subsection{Conclusões}

Este trabalho se propôs a avaliar o comportamento de misturas asfálticas SMA por meio de ensaios de laboratório, comparando com um concreto asfáltico convencional e dando maior destaque à mistura produzida com ligante asfalto-borracha.

As misturas SMA apresentaram resistência à deformação permanente superior à dos concretos asfálticos com graduação contínua. No ensaio de deformação permanente no simulador de tráfego LCPC, as três misturas SMA apresentaram coeficiente angular muito próximo, embora a mistura com asfalto modificado por polímero tenha tido menor deformação a 30.000 ciclos, resultado já esperado devido à ação dos modificadores no desempenho do concreto asfáltico.

A mistura SMA com asfalto-borracha teve um desempenho igual ao da mistura com polímero até os 1.000 ciclos da simulação, e mesmo aos 30.000 ciclos, a diferença entre ambas foi de apenas $0,6 \%$ de deformação, o que equivale a $0,3 \mathrm{~mm}$ de afundamento. Diferença de desempenho tão pequena motiva o uso do ligante asfaltoborracha para misturas do tipo SMA, pois além do custo inferior, a utilização desse tipo de ligante em obras de pavimentação é uma alternativa para a disposição ambientalmente adequada de pneus descartados.

A mistura SMA com asfalto convencional (SMA-AC) teve deformação a 30.000 ciclos um pouco maior que a mistura de referência (CBUQ-AC), contudo, seu coeficiente angular foi bem menor, aproximadamente a metade. Isso indica uma menor 
potencialidade de desenvolver altos valores de deformação permanente com o acúmulo do tráfego.

Uma interpretação dos resultados do ensaio de deformação permanente no equipamento simulador de tráfego LCPC mostra que, em geral, o coeficiente angular da curva de deformação permanente é condicionado pelo tipo de mistura (esqueleto mineral), enquanto que o tipo de ligante define a posição da curva. Ou seja, misturas SMA apresentam menor coeficiente angular que misturas contínuas e o uso de ligantes modificados, por polímero ou por borracha, resulta em menor deformação permanente.

Conforme verificado neste trabalho, as misturas SMA possuem uma película asfáltica mais espessa, da ordem de 50\% maior do que a de uma mistura com granulometria contínua, o que é uma vantagem quanto à inibição do desgaste. Por outro lado, têm uma maior susceptibilidade ao escorrimento do ligante, que é evitado com a utilização de fibras.

Quanto à resistência ao aparecimento e propagação de trincas por fadiga, as misturas asfálticas SMA tiveram um desempenho inferior ao da mistura de referência avaliada neste trabalho. No entanto, seus parâmetros de fadiga são similares aos de concretos asfálticos convencionais publicados na literatura.

\subsection{Sugestões para Trabalhos Futuros}

As misturas asfálticas SMA produzidas neste trabalho foram dosadas para um volume de vazios próximo de $4 \%$, determinado através do ensaio Marshall. Sugere-se a verificação do teor ótimo de ligante por meio de outros ensaios, como por exemplo o ensaio de deformação permanente no simulador de tráfego LCPC e o compactador giratório da Especificação Superpave.

Sugere-se, ainda, verificar o número de golpes por face necessários para compactação das misturas asfálticas SMA quando da utilização do compactador Marshall. 
Para misturas asfálticas SMA com ligante asfalto-borracha, pode-se estudar seu comportamento com diferentes tipos de asfalto-borracha, variando-se, por exemplo, o teor e a graduação da borracha.

Apesar da literatura fazer menção às boas características funcionais das misturas asfálticas SMA, sugere-se verificar, para as condições que prevalecem no Brasil, a resistência à derrapagem, a qualidade do rolamento, a visibilidade e os ruídos do tráfego de pavimentos construídos com revestimento do tipo SMA.

Um problema associado às misturas SMA é o escorrimento do ligante, que motiva a utilização de fibras. Sugere-se, portanto, a investigação do teor de fibras necessário para evitar o escorrimento em função da viscosidade do ligante, pois o ligante asfalto-borracha é muito mais viscoso e poderia requerer um menor teor de fibras. 


\section{REFERÊNCIAS BIBLIOGRÁFICAS}

AASHTO (2000). MP-8 - Specification for Designing SMA. American Association of State Highways Transportation Officials.

AASHTO (2000). PP-41 - Practice for Designing SMA. American Association of State Highways Transportation Officials.

AASHTO (1999). PP-2 - Standard Practice for Mixture Conditioning of Hot Mix Asphalt. American Association of State Highways Transportation Officials.

AASHTO (1997). T-19 - Unit Weight and Voids in Aggregate. American Association of State Highways Transportation Officials.

AASHTO (1993). T-166 - Bulk Specific Gravity of Compacted Bituminous Mixtures Using Saturated Surface-Dry Specimens. American Association of State Highways Transportation Officials.

AASHTO (1999). T-283 - Resistance of Compacted Bituminous Mixture to Moisture Induced Damage. American Association of State Highways Transportation Officials.

ABNT - ASSOCIAÇÃO BRASILEIRA DE NORMAS TÉCNICAS (1993). NBR:12891: Dosagem de Misturas Betuminosas pelo Método Marshall: Procedimento. Rio de janeiro. 
AFNOR (1991a). Deformationon Permanente des Mélanges Hidrocarbonés - Partie 1: Essai d'orniérage. NF P 98-253-1. Association Francaise de Normalisation, Paris, Franca.

AFNOR (1991b). Preparatioon dês Mélanges Hidrocarbonés - Partie 2: Compactage dês plaques. NF P 98-250-2. Association Francaise de Normalisation, Paris, Franca.

ASTM (1997) - Standard Specifications for Asphalt-Rubber Binder. American Society for Testing and Materials. ASTM D6114-1997

BELIGNI, M.; VILLIBOR, D. F.; CINCERRE, J. R. (2000). Mistura Asfáltica do Tipo SMA (Stone Matrix Asphalt): Solução para Revestimentos de Pavimentos de Rodovias e Vias Urbanas. In: REUNIÃO ANUAL DE PAVIMENTAÇÃO, 32., 2000. Anais..., Brasília, DF.

BERTOLlO, S. A. M. (2002). Avaliação Laboratorial de Misturas Asfálticas Densas Modificadas com Borracha Recicladas de Pneus. Tese (Doutorado) - Escola de Engenharia de São Carlos, Universidade de São Paulo, São Carlos. 2002.

BOLZAN, P. E. (2000). Stone-Mastic Asphalt and Micro-SMA as Premium Overlay Asphalt Mixtures on the Ricchieri Highway in Argentina. In: ENCONTRO DO ASFALTO, 15., 2000, Rio de Janeiro. Anais... Rio de Janeiro: Instituto Brasileiro de Petróleo e Gás.

BROWN, E. R. (1993). Evaluation of Stone Mastic Asphalt Used in Michigan in 1991. Transportation Research Record, Washington, D. C., n. 1427, p. 54-60.

BROWN, E. R.; FOO, K. Y. (1991). Evaluation of Variability in Resilient Modulus Test Results (ASTM D 4123). NCAT Report $N^{\circ}$ 91-6, National Center for Asphalt Technology, Auburn, AL, EUA. 
BROWN, E. R. e COOLEY JR., L. A. (1999). Designing Stone Matrix Asphalt Mixtures for Rut-Resistant Pavements. NCHRP Report 425. Transportation Research Board, Washington, D. C., EUA.

CHAVES, J. M.; MOURA, E.; BERNUCCI, L. B.; ALBA, W. (2002). Mistura Asfáltica do Tipo SMA Delgado em um Trecho Experimental de uma Rodovia com Elevado Volume de Tráfego. In: ENCONTRO DO ASFALTO, 16., 2002, Rio de Janeiro. Anais... Rio de Janeiro: Instituto Brasileiro de Petróleo e Gás. CD-ROM.

COOLEY JR., L. A. e BROWN, E. R. (2001). Potential of Using Stone Matrix Asphalt for Thin Overlays. Transportation Research Record, Washington, D. C., n.1749, p. 4652 .

CHOUBANE, B.; SHOLAR, G. A.; MUSSELMAN, J. A.; PAGE, G. C. (1999). TenYear Performance Evaluation of Asphalt-Rubber Surface Mixes. Transportation Research Record, Washington, D. C., n.1681, p. 10-18.

DNER (1995). ME 043/95 - Misturas betuminosas a quente - Ensaio Marshall. Departamento Nacional de Estradas de Rodagem, Rio de Janeiro.

DNER (1997) ME - 153/97 - Agregados em estado compactado seco - determinação da massa especifica aparente. Departamento Nacional de Estradas de Rodagem, Rio de Janeiro.

DNER (1994a). ME 133/94 - Misturas betuminosas - determinação do módulo de resiliência. Departamento Nacional de Estradas de Rodagem, Rio de Janeiro.

DNER (1994b). ME 138/94 - Misturas betuminosas - determinação da resistência à tração por compressão diametral. Departamento Nacional de Estradas de Rodagem, Rio de Janeiro.

DNER (1997). Especificação de serviço DNER-ES 313/97 Pavimentação - concreto betuminoso. Departamento Nacional de Estradas de Rodagem, Rio de Janeiro. 
EAPA - European Asphalt Paving Association (1998). Heavy Duty Surfaces: The Arguments for SMA. Holanda.

EMERY, J. J. et al. (1993). Stone Mastic Asphalt Trials in Ontário. Transportation Research Record, Washington, D. C., n. 1427, p. 47-53.

EMERY, J. (1996). Evaluation of Rubber Modified Asphalt Demonstration Projects. Transportation Research Record, Washington, D. C., n. 1515, p. 37-46.

HADDOCK, J.; PAN, C.; FENG, A. e WHITE, T. D. (1999). Effect of Gradation on Asphalt Mixture Performance. Transportation Research Record, Washington, D. C., n. 1681, p. 59-68.

LANCHAS, S. (1999). Características del Stone Mastic Asphalt SMA. In: CONGRESSO IBERO-LATINOAMERICANO DEL ASFALTO, 10., 1999, Sevilla, Espanha.

LYNN, T. A.; BROWN, E. R. e COOLEY JR., L. A. (1999). Evaluation of Aggregate Size Characteristics in Stone Matrix Asphalt and Superpave Mixtures. Transportation Research Record, Washington, D. C., n. 1681, p. 19-27.

MOGAWER, W. S. e STUART, K. D.(1995). Effect of Coarse Aggregate Content on Stone Matrix Asphalt Rutting and Draindown. Transportation Research Record, Washington, D. C., n. 1492, p. 1-11.

MOTTA, L. M. G.; MEDINA, J.; SOUSA, A. M. (2002). Característica de Fadiga e Resiliência de Concretos Asfálticos Brasileiros. In: ENCONTRO DO ASFALTO, 16., 2002, Rio de Janeiro. Anais... Rio de Janeiro: Instituto Brasileiro de Petróleo e Gás. CDROM.

NAPA - NATIONAL ASPHALT PAVEMENT ASSOCIATION (2002). Designing and Constructing SMA Mixtures - State-of-the-Practice. Quality Improvement Series 122. Lanham, MD, EUA. 
ODA, S. (2000). Análise da Viabilidade Técnica da Utilização do Ligante AsfaltoBorracha em Obras de Pavimentação. Tese (Doutorado) - Escola de Engenharia de São Carlos, Universidade de São Paulo, São Carlos. 2000.

PINTO (1991). Estudo do Comportarmento à Fadiga de Misturas Betuminosas e Aplicação na Avaliação Estrutural de pavimentos. Tese (Doutorado) - COPPE, Universidade Federal do Rio de Janeiro, Rio de Janeiro. 1991.

PREUSSLER, E. S.; PINTO, S.; MEDINA, J. (1981). Determinação da vida de fadiga de concretos asfálticos brasileiros e aplicação no dimensionamento de reforco de pavimentos. In: REUNIÃO ANUAL DE PAVIMENTAÇÃO, 16., 1981. Anais..., Recife, PE.

REIS, R. M. M. (2002). Revestimento Asfáltico Tipo SMA para Alto Desempenho em Vias de Tráfego Pesado. Dissertação (Mestrado). Escola Politécnica, Universidade de São Paulo, São Paulo. 2002.

RUTH, B. E., MORONI I. E.; WEST, R. C. (1993). Evaluation of Stone Matrix Asphalt Mixtures in the Gyratory Testing Machine. In: CONFERENCE ON ASPHALT PAVEMENTS FOR SOUTHERN AFRICA, 6., 1993.

SCHMIEDLIN, R. B. (1998). Stone Matrix Asphalt - The Wisconsin Experience. Transportation Research Record, Washington, D. C., n. 1616, p. 34-41. 